\title{
AVALIAÇÃO DAS FORÇAS GERADAS DURANTE A CONTRAÇÃO DE POLIMERIZAÇÃO DE RESINAS COMPOSTAS, EM FUNÇÃO DO TIPO DE RESINA COMPOSTA, MODO DE ATIVAÇÃO, FONTE DE LUZ E UTILIZAÇÃO DE MATERIAL INTERMEDIÁRIO.
}

Juan Carlos Castañeda-Espinosa

Tese apresentada à Faculdade de Odontologia de Bauru da Universidade de São Paulo, como parte dos requisitos para obtenção do título de Doutor em Odontologia, na área de Dentística

(Edição Revisada) 


\section{AVALIAÇÃO DAS FORÇAS GERADAS DURANTE A CONTRAÇÃO DE POLIMERIZAÇÃO DE RESINAS COMPOSTAS, EM FUNÇÃO DO TIPO DE RESINA COMPOSTA, MODO DE ATIVAÇÃO, FONTE DE LUZ E UTILIZAÇÃO DE MATERIAL INTERMEDIÁRIO.}

Juan Carlos Castañeda-Espinosa

Tese apresentada à Faculdade de Odontologia de Bauru da Universidade de São Paulo, como parte dos requisitos para obtenção do título de Doutor em Odontologia, na área de Dentística

(Edição Revisada)

Orientador: Prof. Dr. Rafael Francisco Lia Mondelli 


\section{JUAN CARLOS CASTAÑEDA ESPINOSA}

Filiação

Naturalidade

Nascimento

1982-1986

1989-1991

2001-2005
Carlos Castañeda Castro ${ }^{+}$

Doris Espinosa de Castañeda

Lima-Perú

2 de janeiro 1965

Curso de Odontologia

Faculdade de Odontologia da Universidade Peruana

Cayetano Heredia.

Curso de Pós-graduação em Dentística, nível de Mestrado, na Faculdade de Odontologia de Bauru, USP.

Curso de Pós-graduação em Dentística, nível de Doutorado, na Faculdade de Odontologia de Bauru, USP. 


\section{DEDICATÓRIA}




\section{DEDICATÓRIA}

\section{À meu pai Carlos ${ }^{+}$}

Por ter dedicado sua vida enteira na procura de achar o melhor caminho para nós, sua família. Hoje é difícil continuar caminhando sem ele, mas a sua lembrança nos da forças para seguir. Voce estará sempre na nossa memória, querido pai.

\section{À minha mae Doris}

Por tudos os momentos de carinho que me da, por toda sua dedicação na arte de ser mae, por tudo isso, meu amor, aprezio e respeito.

\section{À minha esposa Rosana}

Por ter entrado na minha vida com muito amor, ter me dado momentos muitos felices e duas crianças maravilhosas.

\section{Aos meus filhos Melissa e Bruno}

Por me dar o maior motivo de viver. 


\section{AGRADECIMENTOS}




\section{AGRADECIMENTOS}

Aos meus pais Carlos $^{+}$e Doris por ter dedicado tudo esforço na minha formação humana, cultural e profissional. Sem eles, não seria possível eu ter chegado neste momento.

A minha esposa Rosana por seu amor e companhia durante todos estes anos.

Aos meus filhos Melissa e Bruno pelo incentivo a continuar lutando para oferecer para eles um futuro melhor.

À minha irmã Cecilia pela companhia de toda uma vida.

Aos meus sogros Antonio e Maria Cristina pelos detalhes que sempre tem a me ensinar.

Ao meu orientador Prof. Dr. Rafael Francisco Lia Mondelli pela sua amizade e pelo tempo que dedicou na execução deste trabalho. Igualmente à sua sra. esposa Maria Fernanda e seus filhos Giovanni e Rafaella.

Ao Brasil por ter me acolhido como novo cidadão brasileiro. 
À Capes, pelo apoio financeiro durante a realização deste Curso de Doutorado

À Faculdade de Odontologia de Bauru (USP), pelas condições oferecidas para a execução deste trabalho, na pessoa de sua diretora Prof. Dra. Maria Fidela de Lima Navarro.

Ao Presidente da Comissão de Pós-Graduação da Faculdade de Odotologia de Bauru (USP), Prof. Dr. Jose Carlos Pereira.

Aos professores da área de Dentística, Doutores Aquira Ishikiriama, Carlos Eduardo Francischone, Eduardo Batista Franco, José Carlos Pereira, José Mondelli, Maria Fidela de Lima Navarro, Maria Teresa Atta, Rafael Francisco Lia Mondelli e Ricardo Marins Carvalho.

Ao Professor Jose Roberto Pereira Lauris.

Aos meus colegas de Doutorado Celiane, Claudia, Daniela, Daniela, Fábio, Fernanda, Lawrence, Linda, Luiza, Paulo, Rosa.

Às secretárias da área de Dentística Ângela Elisabeth, e Rita.

Aos funcionários da área de Dentística Nelson, Sr. Dito, Júnior, Karen, Zuleica, Zilei.

Aos funcionários do Serviço de Biblioteca da FOB-USP. 
Aos funcionários da Pós-Graduação.

Ao meu amigo Adriano Mondelli pela ajuda para a concretização deste trabalho oferecendo todas as instalações do Instituto Mondelli, mas principalmente agradeço a confiança na minha pessoa.

Ao meu amigo Kenyi Nishiyama por aparecer na hora certa com o motivo certo.

Ao Dr. Antonio Piccino e Família pelas facilidades que me ofereceram todo este tempo, eu agradeço sinceramente.

Aos meus amigos Jamal, Vicente e Luiz por todo o carinho com que foi acolhido em suas familias me fazendo sentir parte delas, pelos momentos de diversão e pela mostra sincera de amizade nos momentos difícieis.

A todas as pessoas que tive a sorte de conhecer durante este tempo e das quais aprendi algo novo, que possa enriquecer eu como ser humano, meu muito obrigado. 
Sumário 


\section{Sumario}

RESUMO

1. INTRODUÇÃO

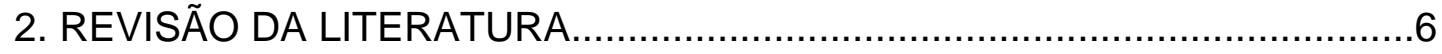

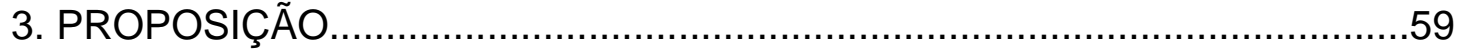

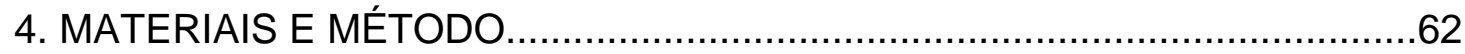

5. RESULTADOS

6. DISCUSSÃO

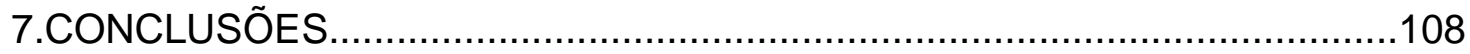

ANEXO

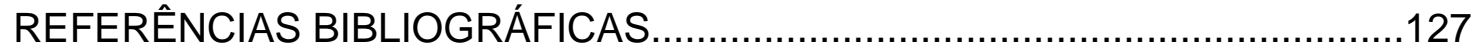

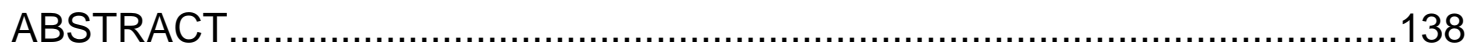


Resumo 


\section{Resumo}

As forças geradas durante a polimerização das resinas estão relacionadas a vários fatores, sendo de muita importância a avaliação das forças que podem alcançar a interface adesiva nestas restaurações. O objetivo deste trabalho foi determinar estas forças, em função da composição e modo de ativação da resina, fonte de luz utilizada na ativação, e presença de material intermediário. Foram utilizadas duas bases de aço em forma retangular $(6 \times 2 \mathrm{~mm})$, posicionadas paralelamente, sendo uma conectada ao braço móvel da máquina de ensaios (Emic - DL 500), através de uma célula de carga de $10 \mathrm{Kgf}$, e outra ao braço fixo. As resinas compostas foram introduzidas entre as bases metálicas, com $1 \mathrm{~mm}$ de altura, volume de $12 \mathrm{~mm}^{3}$ e fator C 1,5. As bases ficaram fixas durante o ensaio, e as forças geradas durante a polimerização foram registradas através de uma curva força/tempo, num total de dez ensaios para cada grupo. Foi avaliada a resina quimicamente ativada Concise (3M), as fotoativadas de micropartículas Filtek A-110 (3M), microhíbrida Filtek Z-250 (3M) e de alta viscosidade Filtek P-60 (3M). Dentre os aparelhos fotoativadores, foi avaliado o halógeno Spectrum (Dentsply), e os LEDs Ultraled (Dabi-Atlante) e Ultrablue IS (DMC). Os materiais intermediários avaliados foram o cimento de íonômero de vidro modificado por resina Vitrebond (3M) e a resina de baixa viscosidade Filtek Flow (3M). Os resultados mostraram que a resina quimicamente ativada Concise apresentou a menor força de contração de polimerização $(4,216 \pm 0,353 \mathrm{~N})$, sendo este valor significantemente menor àqueles apresentados pelas resinas compostas fotoativadas $(p<0,05)$. A resina de micropartículas Filtek $A-110$ apresentou a maior média dentre as resinas fotoativadas $(8,365 \pm 0,5956 \mathrm{~N})$, sem diferenças estatisticamente significativas com Filtek P-60 $(8,111 \pm 0,6868 \mathrm{~N})(\mathrm{p}>0,05)$ e com

diferenças estatisticamente significativas em relação a Filtek Z-250 (7,500 \pm $0,6149 N)(p<0,05)$. Dentre os aparelhos fotoativadores o grupo polimerizado com Ultraled apresentou media significantemente menor que os outros grupos avaliados $(5,175 \pm 0,3480 N)(p<0,05)$. O grupo polimerizado com Spectrum $(6,316$ $\pm 0,2175 \mathrm{~N})$ não apresentou diferenças estatisticamente significativas em relação a 
Ultrablue IS ( $p>0,05)$. Os grupos fotoativados com Ultrablue IS, a densidades de potência de 300 e $600 \mathrm{~mW} / \mathrm{cm}^{2}(6,108 \pm 0,2252 \mathrm{~N}$ e 6,497 $\pm 0,2565 \mathrm{~N}$ respectivamente) mostraram diferenças estatisticamente significativas entre eles $(p<0,05)$. Finalmente, os resultados mostraram que existiram diferenças estatisticamente significativas entre os valores de forças de contração que foram registrados para a resina composta Filtek Z-250 com e sem material intermediário $(p<0,05)$, sendo esta diferença positiva para o Vitrebond e negativa para o Filtek Flow. Pode-se concluir que todas as variáveis estudadas influíram significativamente nas forças de contração de polimerização em maior ou menor grau. 
1. INTRODUÇÃO 


\section{INTRODUÇÃO}

As resinas compostas são materiais híbridos em sua composição, apresentando uma matriz polimérica com inclusão de partículas inorgânicas. A relação destes dois maiores componentes estruturais do material determina suas propriedades físicas, sendo de especial importância os movimentos viscoelásticos do material antes, durante e depois de sua polimerização, assim como as forças que são geradas como conseqüência deste reordenamento molecular (BAUSCH et al. ${ }^{5}, 1982$; VERSLUIS ${ }^{82}$, 1998; RUEGGEBERG ${ }^{64}$, 1999; SAKAGUCHI $\left.{ }^{67}, 1999\right)$.

A matriz polimérica é responsável pelo processo de polimerização, sendo necessário para que isto ocorra, que os monômeros reajam entre si através de ligações covalentes, formando cadeias de polímeros ${ }^{5}$. A distância entre dois monômeros é de 0,3 a 0,4 nm (distância de Van Der Waals). Quando ocorre a polimerização do material é estabelecida uma união covalente com distância de 0,15 nm entre monômeros, aumentando a densidade do material e originando contração volumétrica de aproximadamente 1,5 a $3 \%$ nas resinas compostas atuais. Por ser inerente ao processo de endurecimento do material (polimerização), este fenômeno é inevitável (RUEGGEBERG ${ }^{64}$, 1999; SAKAGUCHI ${ }^{67}, 1999 ;$ SUH $\left.^{71}, 1999\right)$.

Nas primeiras décadas posteriores ao trabalho pioneiro de Bowen ${ }^{8}$, em 1967, sobre forças de contração de polimerização e, com o desenvolvimento das resinas compostas, procurou-se diminuir a quantidade de matriz orgânica e aumentar a porcentagem de partículas inorgânicas, com a finalidade de proporcionar ao material maior resistência à abrasão, melhores propriedades físicas e diminuição da contração volumétrica. Apesar dos avanços tecnológicos das resinas compostas e do desenvolvimento paralelo de novos sistemas adesivos com maior força de resistência de união aos substratos dentários, os 
problemas de integridade marginal, microinfiltração e sensibilidade pós-operatória ainda persistem. Maior entendimento do assunto foi obtido com estudos mais profundos sobre as forças geradas durante a contração de polimerização (DAVIDSON; DE GEE ${ }^{29}$, 1984; FEILZER; DE GEE; DAVIDSON ${ }^{34}$, 1987; KEMPSCHOLTE; DAVIDSON ${ }^{44}$, 1990; VERSLUIS et al. ${ }^{81}$, 1996; VERSLUIS; TANTBIROJN; DOUGLAS ${ }^{82}$, 1998; CONDON; FERRACANE ${ }^{22}$, 1998; CONDON; FERRACANE ${ }^{23}$, 2000).

Assim, em 1982, BAUSCH et al. ${ }^{5}$ explicaram a significância clínica da contração de polimerização e a definiram como o resultado do reordenamento molecular em um espaço menor ao requerido durante a fase líquida do material (gel viscoso). Foi estabelecido que a polimerização de radicais ocorre em três fases: pré-gel, ponto de geleificação e pós-gel.

Diferentemente do que aconteceria se a resina fosse polimerizada livremente no ar, em uma cavidade a contração não acontece livremente como foi pensado inicialmente (DAVIDSON; DE GEE ${ }^{29}$, 1984). As forças de contração geradas internamente no material podem se transmitidas, em parte, à interface adesiva dente-restauração, comprometendo a integridade marginal e apresentando, como conseqüência, a formação de fendas marginais que podem levar a microinfiltração da restauração e à sensibilidade pós-operatória (DAVIDSON; DE GEE; FEILZER ${ }^{31}$, 1984; SAKAGUCHI ${ }^{67}$, 1999; SAKAGUCHI; WILTBANK; MURCHISON ${ }^{70}$, 2004). É nesta situação específica que os valores da força de contração gerada pela resina composta passam a ter maior importância que os valores de contração volumétrica. Segundo VERSLUIS; TANTBIROJN, em 1999, quando não existe contração esta afirmação não é válida, mas com as formulações atuais, todas as resinas sofrem esta pequena contração volumétrica que gira em torno de 1.5 a 3\% (RUEGGEBERG ${ }^{64}$, 1999; $\mathrm{SUH}^{71}, 1999$; SANTOS; SILVA E SOUZA; MONDELLI $\left.{ }^{66}, 2002\right)$. 
Durante a polimerização de um material que apresenta alta fluidez e baixo módulo de elasticidade, na fase pré-gel, o mesmo é capaz de apresentar fluxo interno podendo sofrer deformações livremente nas superfícies não aderidas, sem gerar forças de contração consideráveis (DAVIDSON ${ }^{25}$, 1986). Porém, enquanto a reação vai progredindo, a viscosidade aumenta e sua capacidade de fluxo diminui. Da mesma maneira, o módulo de elasticidade também aumenta e torna a deformação plástica mais difícil (BRAEM et al. ${ }^{10}$, 1987; KEMP-SCHOLTE; DAVIDSON $^{43}$, 1988; KEMP-SCHOLTE; DAVIDSON ${ }^{44}$, 1990). O momento que o material não pode compensar totalmente a contração de polimerização, traduzindo o movimento em forças de contração, é definido como ponto de geleificação (RUEGGEBERG ${ }^{64}$, 1999; SAKAGUCHI ${ }^{67}$, 1999). A contração pós-gel é caracterizada pela formação de forças no material (internamente), conseqüência da impossibilidade deste em compensar a contração de polimerização através de fluxo e da deformação plástica, transformando esse movimento em forças de contração (BAUSCH et al. ${ }^{5}$, 1982; DAVIDSON; DE GEE ${ }^{29}$, 1984; FEILZER; DE GEE; DAVIDSON ${ }^{34}$, 1987; RUEGGEBERG ${ }^{64}$, 1999; SAKAGUCHI ${ }^{67}$, 1999; UNTERBRINK; LIEBENBERG ${ }^{80}$, 1999; VERSLUIS; TANTBIROJN ${ }^{83}, 1999$; MIGUEL; DE LA MACORRA $\left.{ }^{56}, 2001\right)$.

A contração pré-gel não apresenta tanta significância clínica como aquela que acontece a partir do ponto de geleificação, onde a contração gera forças que só podem ser compensadas pelo fluxo do material (DAVIDSON; DE GEE ${ }^{29}, 1984$; CARVALHO et al. ${ }^{12}$, 1996), tipo de materiais (KEMP-SCHOLTE; DAVIDSON ${ }^{43}$, 1987; CASTAÑEDA-ESPINOSA $\left.{ }^{13}, 1991\right)$, configuração da cavidade FEILZER; DE GEE; DAVIDSON ${ }^{34}$, 1987; CASTAÑEDA-ESPINOSA ${ }^{13}$, 1991), técnica de aplicação (DAVIDSON ${ }^{25}$, 1986; KREJCl; LUTZ; KREJCI ${ }^{48}$, 1988; VERSLUIS et $\mathrm{al}^{81}$, 1996) ou tipo de polimerização empregada (BAUSCH et al. ${ }^{5}, 1982$; DAVIDSON; DE GEE ${ }^{29}$, 1984; RUEGGEBERG ${ }^{64}$, 1999; SAKAGUCHI ${ }^{67}$, 1999). Uma vez estabelecida a adesão do material às paredes da cavidade, e sabendo que a resina composta apresenta contração, o sistema restaurador é considerado um sistema de forças onde, por um lado, o sistema adesivo vai procurar alcançar 
sua máxima força de união com os tecidos dentários e, pelo outro lado, a resina vai procurar se contrair, encontrando a resistência da adesão às paredes da cavidade. Nesse momento, o material traduz o movimento em forças chegando, em algumas situações, a superar a força adesiva em alguma das paredes da cavidade, promovendo a formação da fenda marginal (DAVIDSON; DE GEE ${ }^{29}$, 1984; DAVIDSON $\left.{ }^{25}, 1986\right)$.

Estas forças de contração serão geradas somente se não for permitido que o material escoe tudo o que precisar durante sua contração (DAVIDSON; DE $\left.\mathrm{GEE}^{29}, 1984\right)$, porém uma situação de contração livre só poderia acontecer se o material fosse polimerizado sem nenhum contato com outro corpo, não sendo possível de ocorrer no uso odontológico (FEILZER; DE GEE; DAVIDSON ${ }^{34}, 1987$; FEILZER; DE GEE; DAVIDSON ${ }^{36}$, 1990). Estas forças estão diretamente relacionadas com a quantidade de material aderido e a quantidade do material com possibilidade de escoar, relação que foi denominada de "Fator C" (FEILZER; DE GEE; DAVIDSON ${ }^{34}$, 1987), com a capacidade da estrutura dental de sofrer deformação plástica (ALSTER et al. $^{2}$, 1997; BOUSCHLICHER; VARGAS; BOYER $^{7}$, 1997; MEREDITH; SETCHELL ${ }^{55}$, 1997; PAYNE IV ${ }^{61}$, 1999), com o grau de polimerização (SAKAGUCHI ${ }^{67}$, 1999), fonte de luz empregada (densidade de potência e comprimento de onda) (BOUSCHLICHER; VARGAS; BOYER ${ }^{7}, 1997$; FRANCO; LOPES $^{38}$, 2003; SAKAGUCHI ${ }^{67}$, 1999), módulo de elasticidade da resina composta utilizada (KEMP-SCHOLTE; DAVIDSON ${ }^{43}, 1990$; PRATI ${ }^{63}, 1990$ ) e outros fatores ainda não conhecidos.

Considerando a importância das forças de contração de polimerização nas restaurações adesivas, e no intuito de conhecê-las mais profundamente para idealizar técnicas que possam diminuí-las ou controlá-las, foi objetivo deste trabalho avaliar o comportamento destas forças em função do tipo de resina composta, modo de ativação, fonte de luz e utilização de material intermediário. 


\section{REVISÃO DA LITERATURA}




\section{REVISÃO DA LITERATURA}

Poucos anos depois de desenvolver as resinas compostas, BOWEN ${ }^{8}$, observou que, para conseguir manter a adesão entre o material restaurador e as paredes da cavidade, era necessário que a força adesiva deste material ao substrato seja, em todo momento, pelo menos da mesma magnitude que as forças tracionais e de cisalhamento que possam transmitir estresse para esta interface. Segundo o autor, estas forças podem ser originadas, em parte, pela diferença de coeficiente de expansão térmica entre o material restaurador e o dente, pelas forças aplicadas externamente e pela contração volumétrica que acontece durante o endurecimento dos materiais resinosos. A observação de infiltração em dentes extraídos em restaurações realizadas "in vitro" poderia significar que, parte da adesão pode ser quebrada sem necessidade de forças externas, como por exemplo, aquelas geradas durante a mastigação. O autor avaliou também as forças geradas durante a contração de endurecimento de vários materiais. Dentre esses materiais, algumas resinas compostas experimentais foram avaliadas, concluindo que estas podem gerar tensões de até 2,4 Mpa durante a contração de polimerização.

Em 1977, após o trabalho pioneiro mencionado, HEGDAHL; GJERDET ${ }^{42}$, novamente chamaram a atenção das forças que a resina composta poderia gerar quando sua contração livre não é permitida pela técnica adesiva. Avaliaram tanto a contração volumétrica quanto a força de contração de varias resinas compostas quimicamente ativadas. Para avaliação da força de contração usaram um cilindro de $4 \mathrm{~mm}$ de diâmetro e $5 \mathrm{~mm}$ de comprimento, que foi polimerizado entre o braço móvel e estacionário de uma máquina de ensaios Instron. Os valores de força tracional foram registrados continuamente durante a polimerização e durante as duas horas posteriores. Observaram que a contração volumétrica de um corpo de resina polimerizado em condições livre estaria relacionada com as forças de contração geradas pelo mesmo corpo quando é polimerizado em condições restritas. Ambas curvas seguiram o mesmo padrão indicando que, quanto maior a 
contração de uma resina, maiores serão as forças desenvolvidas quando a contração não for permitida. Os valores máximos de força de contração medidos foram 1,21 Mpa para Adaptic, 1,30 Mpa para Concise e 1,92 Mpa para Restodent.

Em 1982, BAUSCH et al. ${ }^{5}$ explicaram que a contração de polimerização é o resultado do reordenamento molecular em um espaço menor àquele requerido no estado líquido, onde as moléculas teriam certa mobilidade. Assim, após a iniciação, aconteceria uma grande contração da massa ainda em estado plástico. Esta contração, segundo os autores, não teria tanta significância clínica como aquela que aconteceria a partir do início da geleificação ou transformação gradual do líquido viscoso em um material rígido, onde a contração começa a gerar tensões que só poderão ser compensadas pelo escoamento do material. Quando a resina composta é aplicada em uma cavidade e aderida a suas paredes, pouco se pode dizer sobre os movimentos internos (fluxo do material). Segundo os autores, quando existe adesão às paredes da cavidade, a resina composta pode apresentar dois comportamentos distintos: a resina cede sem transmitir tensões às paredes da cavidade ou ocorre o rompimento da ligação adesiva das paredes da cavidade. Uma situação intermediária poderia ser possível, gerando tensões internas no material. Quando a resina composta apresenta suficiente flexibilidade, estas tensões podem ser compensadas, porém nas resinas compostas com alto módulo de elasticidade isto não é possível, podendo-se gerar rachaduras na matriz e degradação do material. Finalmente, os autores concluíram que a contração de polimerização é um dos fatores mais importantes em determinar a longevidade das restaurações de resina composta.

Assim, em 1983, BOWEN; NEMOTO; RAPSON ${ }^{9}$ avaliaram o estresse gerado durante a contração de polimerização da resina composta e acrílica. Para avaliar a influência da adesão às paredes da cavidade e do desenho cavitário, a pesquisa foi realizada em três grupos. Nos grupos $n^{\circ} 1$ e $n^{\circ} 2$ foram utilizadas cavidades de alumínio rugoso, para promover adesão da resina composta às 
paredes. No grupo $\mathrm{n}^{\circ} 1$ foi deixada toda uma superfície livre, enquanto no grupo $\mathrm{n}^{\circ} 2$ foi deixado livre somente um orifício, através do qual foi injetado o material. No grupo $n^{\circ} 3$, o material utilizado nas paredes da cavidade foi o teflon, evitando qualquer adesão da resina composta. Foi observado que os resultados diferiam entre os três grupos, sendo que o grupo $n^{\circ} 3$ mostrou valores inferiores que os demais, enquanto maiores valores foram obtidos com o grupo $n^{\circ} 2$. Em função das resinas avaliadas serem de ativação química, estas acumularam uma tensão máxima após 30 minutos de sua ativação. Os autores acrescentaram que as resinas compostas desenvolveram tensões similares às resinas acrílicas durante a contração de polimerização, fato interessante em função das resinas compostas apresentarem contração volumétrica menor. Neste estudo foram registrados valores de até 7,6 Mpa para a resina composta Isopast e 7,2 Mpa para a resina acrílica Sevriton. Os autores concluíram que tensões significantes são geradas durante a contração do material quando existe adesão às paredes da cavidade. Sendo assim, para esta adesão ser clinicamente aceitável, tem que ser desenvolvida rapidamente e, principalmente, em todo momento ser superior às forças geradas durante a polimerização do material.

Também estudando o comportamento da resina composta durante a polimerização livre e restrita (devido à adesão às paredes da cavidade) DAVIDSON; DE GEE ${ }^{29}$, em 1984, avaliaram duas resinas compostas e observaram que só $12 \%$ (3,9Mpa) e 4\% (2,8Mpa) das forças teóricas, que deveriam ser geradas para Silar e Concise respectivamente, foram registradas em condições experimentais, atribuindo a liberação de tensões à capacidade de fluxo interno e escoamento na superfície livre em cada resina. Os autores acrescentaram que durante a contração de polimerização em condições restritas, as tensões geram fluxo do material que alivia parcialmente os efeitos da contração. Nos períodos iniciais da polimerização, a contração é máxima, mas afortunadamente o material é fraco e capaz de ceder. Após alguns minutos, o material ganha resistência, mas ele não precisa ceder muito mais, em função da diminuição da contração durante o período final da reação. Ainda observaram que 
os valores máximos de estresse de contração de polimerização são dependentes do aparelho de medição, e principalmente, da célula de carga utilizada para traduzir movimento em força, sugerindo a utilização de células de carga de baixos valores. O tamanho do espécime e o diâmetro também foram considerados de importância em função da contração transversal. Finalmente, eles concluíram que quando existe uma boa adesão inicial às paredes da cavidade, o material vai fluir durante a polimerização e a adaptação marginal pode ser mantida.

Em outro estudo, ainda nesse ano, DAVIDSON; DE GEE; FEILZER ${ }^{31}$ avaliaram a influência das forças da contração de polimerização de duas resinas compostas de micropartículas sobre a interface adesiva utilizando adesivo (Scotchbond). Dentre as resinas avaliadas uma foi fotoativada (Silux) e a outra quimicamente ativada (Silar). Para a avaliação utilizaram-se três parâmetros; primeiramente foi determinada a força de contração de cada resina durante a polimerização, para depois determinar a resistência de união do adesivo dentinário, ambos em diferentes períodos de tempo. Finalmente foi avaliada a existência ou não de microinfitração em restaurações de classe $\mathrm{V}$ realizadas com os mesmos materiais. Os valores de resistência de união foram superiores em todos os períodos avaliados, quando comparados com as forças geradas durante a contração linear das resinas compostas, que alcançaram valores de até 2,4Mpa, depois de 30 minutos. Foi observada a existência de microinfiltração em quase $100 \%$ das paredes de dentina das restaurações. Os autores explicaram que quando a contração é restrita a uma direção (contração linear restrita) a adesão não é afetada, porém quando esta acontece em condição restrita tridimensionalmente (contração volumétrica restrita) nenhuma adesão à dentina seria capaz de suportá-la. Assim, quando existem poucas paredes cavitárias (onde o material esta aderido e vai experimentar uma contração restrita) a contração pode ser compensada pelo escoamento da resina composta. Esta liberação de tensões não acontece quando a cavidade apresenta só uma superfície livre, onde estas tensões podem alcançar até $20 \mathrm{Mpa}$, dependendo da configuração da cavidade. Em função da força coesiva da resina composta ser 
ainda maior, não vai acontecer uma falha coesiva e sim uma falha adesiva na interface com a dentina. Finalmente os autores concluíram que não só devem ser desenvolvidos adesivos com força adesiva maior, como também resinas compostas com contração de polimerização menor, assim como desenhos cavitários apropriados para restaurações deste tipo.

Ainda DAVIDSON ${ }^{25}$, em 1986, enfatizou que o sucesso de restaurações adesivas de resinas compostas só poderia ser alcançado com uma aplicação disciplinada e boa técnica. Acrescentou que a técnica incremental mostra-se vantajosa com as resinas compostas fotoativadas, sempre que o primeiro incremento seja aderido só a uma parede cavitária (preferivelmente de dentina), para permitir o fluxo do material nessa direção, a partir da superfície livre da cavidade.

Para comprovar a importância do desenho cavitário, FEILZER; DE GEE; DAVIDSON $^{34}$, em 1987, avaliaram as forças geradas durante a contração de polimerização de corpos de prova de resina composta com "fator de configuração" conhecido, que foi calculado da relação matemática entre área de superfície aderida às paredes da cavidade, e área de superfície livre do corpo de prova. Foi observado que quanto maior foi o fator de configuração, maiores foram as tensões geradas durante a contração de polimerização e, o que é pior, estas alcançaram valores altos de forma mais rápida. Os autores explicaram que o material aproveita a superfície livre para ceder e aliviar as conseqüências da contração restrita. Assim, restaurações com superfície livre proporcionalmente menor (fator C alto) apresentam menores condições de aliviar estas forças. Sendo assim, fatores de configuração altos devem ser evitados. Ainda observaram que o volume do material não incrementa estas forças, sempre que se mantenha o fator $\mathrm{C}$ constante. Finalmente concluíram que na maioria de cavidades a capacidade de liberar tensões a través do fluxo do material não é suficiente para preservar a adesão obtida com os adesivos dentinários. 
BRAEM et al. ${ }^{10}$ em 1987 estudaram o aumento do módulo de elasticidade durante a polimerização de resinas compostas. Avaliaram quatro resinas compostas quimicamente ativadas e duas resinas compostas fotoativadas. Observaram que entre as resinas compostas quimicamente ativadas existiu diferença significativa, no entanto em todos os casos esses materiais apresentaram um incremento do módulo de elasticidade mais lento quando comparado com as resinas compostas fotoativadas, onde o aumento do módulo de elasticidade aconteceu nos primeiros segundos. Acrescentaram que o aumento lento do módulo de elasticidade poderia favorecer o fluxo interno e escoamento do material durante a polimerização, permitindo a formação de adequada ligação adesiva, o que poderia resolver parcialmente o problema da competição entre a adesão e a força de contração.

Em 1988, KEMP-SCHOLTE; DAVIDSON ${ }^{43}$ estudaram a influência do módulo de elasticidade da resina composta sobre as tensões geradas durante sua contração linear, explicando que estas últimas expressam o produto da contração linear pelo módulo de elasticidade do material. Resinas compostas com módulo de elasticidade maior desenvolveriam maiores tensões durante a contração de polimerização. Por outro lado, o baixo módulo de elasticidade dos adesivos aliviaria em parte estas tensões. Em algumas resinas compostas com alto módulo de elasticidade esta liberação de tensões não é suficiente para diminuir as tensões até valores inferiores aos valores de resistência de união dos adesivos, propiciando a desaderência do material das paredes da cavidade. Neste estudo, só as resinas compostas com baixo módulo de elasticidade mantiveram uma boa adaptação marginal após sua polimerização. Ainda foi observado que a aplicação de uma resina fluida depois de terminada a restauração forneceu um perfeito selamento das margens de restaurações realizadas com resina composta de baixo módulo de elasticidade (Silux), enquanto que o mesmo procedimento não foi eficiente para resina de alto módulo de elasticidade (P-30). Finalmente os autores 
concluíram que o módulo de elasticidade da resina composta influiu significantivamente na adaptação da restauração.

KREJCI; LUTZ; KREJCI ${ }^{48}$, ainda em 1988, avaliaram a influência da utilização de diferentes materiais de base sobre a adaptação marginal e o desgaste de restaurações de classe II de resina composta. Compararam os seguintes materiais e condições: base de cimento de ionômero de vidro; base de cimento de ionômero de vidro condicionado com ácido fosfórico; cimento de fosfato de zinco; hidróxido de cálcio quimicamente ativado; hidróxido de cálcio fotoativado e restauração sem base. Observaram que a seleção do material de base influiu no comportamento de restaurações de classe II de resina composta. Em todos os grupos o comportamento foi superior antes da ciclagem mecânica, sendo que depois desse procedimento os grupos que receberam o cimento de ionômero de vidro sem condicionar e o cimento de fosfato de zinco apresentaram a maior percentagem de margens excelentes. A restauração onde não foi utilizado material de base apresentou as piores margens, sendo explicados esses resultados pela ausência de material de base flexível que possa absorver tensões existentes na restauração. Por outro lado, o cimento de hidróxido de cálcio aparece como um material excessivamente flexível, criando condições para maior deformação da resina composta, o que poderia trazer como conseqüência menor qualidade de margens. Segundo os autores, aparentemente existe um valor de módulo de elasticidade entre 5 e $10 \mathrm{MN} / \mathrm{m}^{2}$ que seria favorável para apresentar melhor qualidade de margens e manter uma boa resistência ao desgaste.

HANSEN; ASMUSSEN ${ }^{41}$ estudaram, em 1989, a adaptação marginal de resinas compostas e avaliaram o efeito da utilização de adesivos dentinários e a expansão higroscópica. A contração de parede a parede foi medida em cavidades preparadas e restauradas em dentes humanos extraídos depois de 10 minutos da polimerização e depois de 28 dias expostos à absorção de água. Foi utilizada uma resina de micropartículas como grupo controle, por ser uma resina composta 
indicada para o setor anterior, e duas resinas indicadas para o setor posterior. As três resinas foram avaliadas utilizando ou não um adesivo dentinário. Os resultados mostraram que nenhum dos adesivos foi capaz de evitar a formação de fendas entre as paredes da cavidade e a restauração, porém os resultados obtidos com resina de micropartículas foram significantemente melhores do que com resinas indicadas para dentes posteriores. Depois de 28 dias foi observado que restaurações confeccionadas com resina composta de micropartículas tinham fechado a fenda entre a restauração e o dente, enquanto as resinas posteriores não apresentaram o mesmo comportamento. Os autores atribuíram os resultados à alta viscosidade das resinas posteriores e ao fato de apresentarem menor conteúdo orgânico e conseqüentemente, menor expansão higroscópica. Acrescentaram que a absorção de água pode ser prejudicial para algumas propriedades físicas da resina, mas ajuda a fechar a fenda marginal ou diminuir tensões de contração de polimerização, pela pequena absorção de água apresentada.

Responsabilizando à contração de polimerização das resinas compostas pela formação precoce de uma fenda na interface dente-restauração, PRATI ${ }^{62}$, em 1989, avaliou a microinfiltração imediata de várias resinas compostas da época, quando utilizadas com sistemas adesivos ou cimento de ionômero de vidro. Observou que as resinas compostas com maior quantidade de carga apresentaram os piores resultados, atribuindo estes valores ao alto módulo de elasticidade desses materiais (P-30, P-50). Quando as mesmas resinas foram associadas com cimento de ionômero de vidro os resultados foram ótimos e a combinação Vitrebond; SB 2; P-50 obteve os melhores resultados. O autor mencionou que o fluxo do material durante a polimerização é uma característica desejada para compensar a contração, acrescentando que resinas compostas mais flexíveis também são mais efetivas em selar as margens da restauração. Tanto módulo de elasticidade como fluxo são dependentes da composição do monômero e da quantidade de partículas de carga. 
KEMP-SCHOLTE; DAVIDSON ${ }^{44}$ estudaram, em 1990, o efeito de utilizar bases de materiais mais flexíveis, para conseguir aliviar parte das forças geradas durante a contração de polimerização. Para tanto, verificaram a capacidade de vedamento de restaurações realizadas com dois adesivos utilizando duas técnicas de inserção do material (incremento único ou incremental) e fizeram medições das forças geradas por cada combinação avaliada. Os resultados demonstraram que nenhum dos adesivos (SB1, SB2) foi capaz de resistir às forças geradas durante a contração de polimerização da resina composta quando aplicados sem nenhum material intermediário, independentemente da técnica de aplicação utilizada. A aplicação de uma resina fluida nas margens, depois de terminada a restauração aumentou a integridade marginal destas restaurações. A técnica mista realizada com ionômero de vidro convencionais também não foi capaz de evitar a microinfiltração, enquanto nos espécimes restaurados com ionômeros modificados com resina (Vitrebond; Ioline; Zionomer) ou uma resina fluida (Silux enamel bond) inserida neste caso depois da aplicação de adesivo dentinário, as restaurações mantiveram sua união com as paredes da cavidade. Nesses casos, os valores das tensões de contração de polimerização da resina composta, transmitidas através dos materiais intermediários não excederam os 5Mpa, enquanto que em restaurações sem material intermediário os valores foram significantemente maiores. Ainda foi observado que materiais com maior módulo de elasticidade promovem maiores tensões, e o aumento da espessura do material intermediário de baixo módulo de elasticidade promove diminuição destas tensões. Os autores concluíram que a aplicação de um material de baixo módulo de elasticidade como camada intermediária reduz efetivamente a transmissão de forças em direção às margens da restauração, propiciando um excelente selamento marginal, sempre que a adesão do material intermediário à dentina seja maior que $5 \mathrm{Mpa}$.

Ainda KEMP-SCHOLTE; DAVIDSON ${ }^{45}$, o mesmo ano, avaliaram a integridade marginal de restaurações de classe $\mathrm{V}$ realizadas com diferentes 
resinas compostas e diferentes adesivos. Também foi avaliada a influência da utilização de uma resina fluida (Silux Enamel Bond) como material intermediário e, finalmente, o efeito da ciclagem térmica. Foi observado que existiu uma relação inversamente proporcional entre a qualidade da margem e o módulo de elasticidade da resina composta utilizada. As resinas quimicamente ativadas ( $P$ 10; Silar) promoveram melhores margens que suas equivalentes fotoativadas ( $P$ 30; Silux), resultado atribuído pelos autores à melhor capacidade de fluxo nas resinas compostas quimicamente ativadas, fato que compensaria melhor as forças geradas durante a contração de polimerização. A aplicação de um material intermediário de baixo módulo de elasticidade melhorou a adaptação marginal, possivelmente em função do aumento de flexibilidade da restauração. A ciclagem térmica não modificou a qualidade das margens. Os autores acrescentaram que para uma boa adaptação marginal são necessários adesivos com mínima força de união, mas que outros fatores como o módulo de elasticidade do material restaurador devem ser necessariamente controlados. Finalmente concluíram que a integridade marginal está inversamente relacionada com o módulo de elasticidade da resina composta utilizada.

Outra forma de compensar o estresse de polimerização foi sugerida por FEILZER; DE GEE; DAVIDSON ${ }^{35}$. Esses autores estudaram a diminuição do estresse de polimerização, através da expansão higroscópica de resinas de diversas formulações, sendo de ativação química ou fotoativadas. As amostras foram armazenadas em água a $37^{\circ} \mathrm{C}$, e a curvatura das tiras que correspondia à deflexão do material, e conseqüentemente à tensão desenvolvida pelo estresse na resina, foi medida após uma hora de imersão e, posteriormente, periodicamente durante dois meses. Para cada grupo, uma amostra não foi imersa em água para controle. A partir das medições das deflexões, foi possível calcular o estresse máximo através da medição da tangente da curvatura na resina, próxima à interface adesiva, podendo-se, então, estimar o estresse máximo nas extremidades das tiras. Nas amostras mantidas secas, a deflexão do material continuou a ocorrer com o tempo como conseqüência de um estresse contínuo 
pós-polimerização. Para os materiais à base de triciclodecano dimetacrilato, houve pouco relaxamento pela expansão higroscópica devido à sua natureza mais hidrofóbica e saturada. Para os materiais à base de Bis GMA/TEGMA e UDMA, o estresse de contração de polimerização foi completamente diminuído ou convertido em um "estresse de expansão" através da expansão higroscópica.

Ainda nesse ano, FEILZER; DE GEE; DAVIDSON ${ }^{36}$ avaliaram redução de estresse através do escoamento das resinas compostas ativadas quimicamente em relação à configuração cavitária. Foram estudadas cavidades com diferente fator de configuração $(0.5,2.0,2.5$ e 5.0). Os valores volumétricos da contração de polimerização foram determinados num período de 60 minutos através de um dilatômetro de mercúrio modificado. De acordo com os resultados pôde-se concluir que a redução do estresse através do escoamento foi dependente da resina utilizada e da configuração cavitária. Os autores também concluíram que o escoamento de um material resinoso contribuiu grandemente com a redução do estresse de contração em restaurações com baixo valor de fator-C e foi insuficiente em cavidades em que este valor foi alto.

MITRA $^{58}$, em 1991, verificou algumas propriedades do Vitrebond e as comparou com um cimento de ionômero de vidro convencional (3M Glass Ionomer). Para os testes de resistência ao cisalhamento foram utilizadas superfícies planas de dentina bovina. Os cimentos de ionômero de vidro foram aplicados sobre estas superfícies e, no caso do Vitrebond, polimerizado por 30 segundos. Realizado este procedimento foi aplicado adesivo Scotchbond DC ou Scotchbond 2 sobre a superfície de $3 \mathrm{M}$ Glass lonomer e Vitrebond respectivamente. Depois de polimerizar o adesivo, foi aplicada a resina composta (P-30). Os espécimes foram armazenados em água e submetidos à ciclagem térmica antes de realizar os testes de resistência a forças de cisalhamento. Após armazenamento por 24 horas em água, a resistência de união foi de 12 MPa para o Vitrebond e $4 \mathrm{MPa}$ para o 3M Glass Ionomer. A adesão imediata obtida para 
estes cimentos foi de $7 \mathrm{MPa}$ e $2 \mathrm{MPa}$ respectivamente. Testes após períodos de até 10 meses mostraram que a adesão do Vitrebond não diminuiu por ação da água. De igual forma a ciclagem térmica não alterou os valores de adesão. No espécime aderido à dentina humana a força de união foi de $15 \mathrm{MPa}$ após armazenamento em água por 24 horas. A autora explicou que a reação de endurecimento do Vitrebond envolve uma reação ácido-base e um processo de polimerização. A reação ácido/base é iniciada ao misturar os componentes e continua até formar a típica rede de cadeias cruzadas unidas por ligações iônicas. Quando o cimento foi exposto a uma fonte de luz, as cadeias de poliânions, ainda não ligadas iônicamente, teriam polimerizado através de grupos polimerizáveis presentes nos extremos destas cadeias, provocando o endurecimento do cimento através de ligações covalentes. Desta forma, no cimento totalmente endurecido, as cadeias de policarboxilatos são ligadas através de ligações iônicas e covalentes, resultado da reação ácido-base e do processo de polimerização que ocorrem simultaneamente, porém independentemente.

Nesse mesmo ano, UNO; ASMUSSEN ${ }^{79}$ propuseram uma técnica de polimerização nova, observando que até então os adesivos não tinham sido capazes de evitar os efeitos destrutivos da contração de polimerização. Os autores observaram que estudos anteriores (DAVIDSON; DE GEE ${ }^{29}$, PRATI' ${ }^{62}$ ) mencionaram a importância do livre escoamento do material durante a polimerização para não gerar forças de contração. Postularam que uma polimerização mais lenta poderia permitir maior escoamento do material durante este processo. Sendo assim, o propósito desse estudo foi avaliar o efeito de uma polimerização com baixa densidade de potência sobre a adaptação marginal, adesão e resistência à compressão. O estudo foi realizado em dentes humanos extraídos, onde foram confeccionadas cavidades com todas as margens em dentina. A largura máxima da fenda entre a restauração e o dente foi medida através de microscopia ótica. Foi observada melhor qualidade de margens quando uma técnica de polimerização inicial com baixa densidade de potência foi utilizada. Os valores de resistência adesiva e forças de compressão mostraram que não 
ocorreu perda significativa quando a polimerização inicial foi seguida de uma irradiação com alta densidade de potência. Os autores concluíram que uma polimerização inicial com baixa densidade de potência seguida de uma polimerização com alta densidade de potência poderia ser uma alternativa para melhorar a adaptação marginal em restaurações de resina composta.

TAM; Mc COMB; PULVER ${ }^{75}$ avaliaram algumas propriedades físicas e químicas de diferentes materiais utilizados para forramento, entre eles o cimento de ionômero de vidro modificado com resina Vitrebond. As propriedades estudadas foram: resistência compressiva, diametral e flexural, módulo de elasticidade, liberação de flúor e cálcio e o pH. O valor do módulo de elasticidade para Vitrebond com a metodologia utilizada foi de 1.1GPa, valor medido depois de 24 horas de armazenamento em água.

Em 1993, FEILZER; DE GEE; DAVIDSON ${ }^{37}$ investigaram o desenvolvimento do estresse de polimerização de resinas fotoativadas, com e sem inclusão de porosidades, em relação ao fator de configuração cavitária e compararam os resultados com resinas de ativação química. As resinas foram inseridas e polimerizadas entre duas placas de vidro aderidas a um dispositivo específico ligado a um tensiômetro, que verificava a distância das duas placas de acordo com as alterações provocadas pela contração ou pelas alterações térmicas. Nos casos em que o valor de fator-C excedeu a 2, as mensurações terminaram antes, em função de falha coesiva do material ou na interface vidromaterial. Para os valores maiores do que $17 \mathrm{MPa}$, ocorreram falhas coesivas nos discos de vidro, não sendo possível determinar o valor da falha coesiva da resina $\mathrm{P}-30$, quando $\mathrm{C}=2$. $\mathrm{O}$ estresse se desenvolveu a maior velocidade e até maiores valores finais para os materiais fotoativados quando comparados com os quimicamente ativados. As resinas fotoativadas resistiram melhor ao estresse inicial, e apresentaram menor capacidade de escoar quando comparadas com as resinas quimicamente ativadas análogas. Finalmente, a inclusão de porosidades 
no interior as resinas fotoativadas, diminuiu e tornou mais lento o desenvolvimento do estresse na reação.

RUEGGEBERG; TAMARESELVY ${ }^{65}$ (1995), mencionaram que o grau de conversão estaria relacionado com as propriedades físicas da resina composta, e que uma delas é a contração de polimerização. Assim, propuseram a possibilidade de medir o grau de polimerização de resinas a partir da determinação da contração de polimerização do material. Com esse propósito foram comparados os graus de polimerização, determinados através da contração volumétrica, com um dos métodos tradicionais para determinar grau de conversão (espectroscopia infravermelha). Os resultados não mostraram serem estatisticamente diferentes. Os autores concluíram que a contração de polimerização é válida como instrumento para determinar o grau de polimerização da resina.

CARVALHO et al. $^{12}$, em 1996, em uma revisão da literatura sobre contração de polimerização, afirmaram que a inserção de resinas compostas adesivas nos preparos cavitários leva a competição entre as forças de contração de polimerização e a força de adesão à estrutura dental. Relataram que a velocidade de formação do estresse de polimerização pode ser controlado em parte, pelo desenho da cavidade (fator $\mathrm{C}$ ), uso de bases, tamanho, forma e posição dos incrementos de resina composta colocados na cavidade e, ainda, modo de ativação da resina composta. A compensação ou alívio do estresse pode ser conseguido, segundo os autores, mantendo o fator C o mais baixo possível, utilizando resinas quimicamente ativadas, bases com baixo módulo de elasticidade e, com o passar do tempo, pela sorção de água. Concluíram que o entendimento desses princípios permite aos clínicos obter maior controle do estresse de polimerização, melhorando a qualidade das restaurações adesivas.

VERLUIS et al. $^{81}$ realizaram um estudo, também em 1996, no qual relataram que é amplamente aceito que a contração volumétrica e a solidificação 
durante o processo de polimerização das resinas compostas, em combinação com a adesão às estruturas dentárias duras resultam em transferência de estresse e deformação das paredes da cavidade de dentes restaurados. Questionaram a técnica incremental em função da possibilidade desta técnica não diminuir o estresse de polimerização do material. Os autores analisaram numericamente 0 desenvolvimento dos campos de estresse para diferentes técnicas incrementais e os resultados mostraram que, em uma restauração com adesão adequada ao dente, a técnica incremental aumentou a deformação do dente restaurado, levando à formação de uma estrutura dente-resina com níveis mais altos de estresse. Concluíram que a técnica incremental pode ser necessária em função de outras razões, mas não aos efeitos da contração de polimerização.

BOUSCHLICHER; VARGAS; BOYER ${ }^{7}$ (1997) estudaram os efeitos do tipo de resina composta, intensidade de luz, fator de configuração cavitária e polimerização a laser sobre a força de contração de polimerização das resinas compostas. Utilizaram hastes de vidro, que depois de condicionadas com ácido fluorídrico e silanisadas, foram tratadas com sistema adesivo e adaptadas a uma máquina de ensaios. Foram avaliadas as resinas Silar (polimerização química), Silux Plus (micropartículas) e Z100 (partículas híbridas) e a polimerização foi efetuada com luz convencional do aparelho Demetron 401, lasers ILT Modelo D5500 (LAC) e Modelo 5500 ABL (LWC). Os resultados mostraram que a resina quimicamente ativada obteve o menor valor de forças de contração de polimerização, enquanto a resina fotoativada híbrida obteve o maior valor. A força de contração desenvolveu-se a maior velocidade nas resinas fotoativadas do que na ativada quimicamente; aumentando a intensidade de luz aumentou-se também a força máxima de contração; a força máxima de contração mostrou-se inversamente proporcional ao fator $\mathrm{C}$ e diretamente proporcional ao volume do material restaurador. As forças obtidas pela polimerização com laser foram similares para os dois grupos, sendo ambas estatisticamente menores que a polimerização por luz convencional. 
Ainda em 1997, MEREDITH; SETCHELL ${ }^{55}$ consideraram que a contração de polimerização poderia causar movimento de cúspides em dentes posteriores, e avaliaram em cavidades MOD esse movimento e o estresse induzido nessas cúspides através de lâminas de tensão ("strain gauge"). As restaurações foram feitas utilizando as resinas compostas P-30 e P-50 e o adesivo Scotchbond e Scotchbond 2. Observaram que nem o aumento de pressão por parte da matriz, nem a polimerização do adesivo promoveram deflexão de cúspides. Quando o material restaurador foi polimerizado foi observada leitura positiva tanto pelas lâminas de tensão quanto na medição feita nas cúspides. Tanto cúspides linguais quanto vestibulares foram tencionadas e mostraram uma deflexão em direção à restauração. Segundo os autores esse comportamento foi conseqüência da transmissão da força de contração de polimerização desde a resina composta através do adesivo até as paredes da cavidade. Os maiores valores de estresse de contração foram medidos durante o procedimento de polimerização e, segundo os autores, não foi observado nenhum tipo de liberação de estresse através do escoamento do material desde que os valores de tensão não diminuíram em nenhum momento da medição. Os maiores valores de tensão foram medidos no incremento oclusal e segundo esses autores possivelmente esse último incremento seja a maior causa da falha da restauração. Finalmente afirmaram que devem ser pesquisados métodos para reduzir o estresse de contração.

Com o intuito de contribuir para o reconhecimento e entendimento dos problemas relacionados com a contração de polimerização, DAVIDSON; FEILZER ${ }^{32}$ publicaram uma revisão sobre o tema em 1997. Foram estudadas as mudanças dimensionais que ocorrem durante a polimerização das resinas compostas para diferenciar a contração volumétrica, o estresse de contração e a compensação desse estresse. Comentaram que a polimerização da matriz resinosa produz a geleificação, onde o material restaurador é transformado de uma fase visco-plástica a uma fase rígido-elástica. O ponto de geleificação foi definido como o momento no qual o material não pode prover mais de um fluxo viscoso que acompanhe a contração de polimerização. Desta maneira, os 
resultados obtidos através de dispositivos que requeiram força para seu movimento e imediata tradução a tensão só poderiam registrar valores na fase "pós-gel", onde o material é suficientemente forte para gerar e transmitir forças. Relataram que o estresse de contração de polimerização pode ser visto como o mecanismo que é responsável por problemas com as restaurações adesivas e pode causar a separação do material restaurador da cavidade ou fraturas coesivas em uma das estruturas. Afirmaram que a magnitude do estresse de contração é dependente também das propriedades do material restaurador, com os materiais mais rígidos causando maior estresse de contração, sendo que a compensação do estresse de contração pode ser conseguido ao permitir a contração livre do material em direção da interface adesiva, evitando incrementos de resina que aderem paredes opostas, ou pela utilização de bases cavitárias para a melhor distribuição do estresse na restauração e interface adesiva. Ainda mencionaram a possibilidade de obter resultados com alta percentagem de erro quando máquinas de ensaio são utilizadas para a verificação do estresse de contração em corpos de prova de diferente volume e, sobretudo altura (entre as bases unidas à máquina de ensaio) sem serem consideradas a deformação do dispositivo e a célula de carga. Eles sugerem a utilização de um dispositivo retroalimentador, onde a distância entre as bases onde é inserido o material seja mantida constante, chamando esta montagem de rígida. Finalmente, concluíram que não existem métodos de manipulação de restaurações descritos que garantem uma restauração à prova de falhas, de forma que o profissional tem que aceitar o problema da contração de polimerização e seu destrutivo estresse de polimerização.

Ainda no mesmo ano, com o objetivo de investigar, através de diferentes métodos, o efeito da espessura da camada de resina composta no estresse de contração de polimerização, ALSTER et al. ${ }^{2}$ realizaram um trabalho no qual afirmaram que, uma vez que o valor de contração de polimerização é dependente do dispositivo em que é medido, um método para testar esse dispositivo deveria ser testado. Utilizaram a resina Clearfil F2 da Kuraray (ativação química). O 
estresse de contração foi determinado para corpos de prova de resina de alturas de 50, 100, 200, 300, 400, 500, 600, $700 \mu \mathrm{m}, 1.4$ mm e 2,7 mm. A concordância dos dispositivos utilizados foi calculada com a ajuda de análise de regressão não linear, usando uma equação derivada da Lei de Hooke como modelo. Os resultados mostraram que os valores de contração diminuíram com o aumento da altura dos corpos de prova cilíndricos de resina composta, fato explicado pela teoria de que quanto maior a área de superfície livre em relação à área das superfícies aderidas, maior seria a capacidade de escoamento do material e conseqüentemente menor o estresse de contração. Afirmaram que o método de medição para determinar o estresse de contração de polimerização de resinas compostas iniciadas quimicamente foi aceitável.

Em 1998, CONDON; FERRACANE ${ }^{22}$ realizaram um trabalho com o objetivo de determinar a redução do estresse de polimerização das resinas através da adição de micropartículas não adesivas. Para isso, adicionaram a uma resina de partículas pequenas e a uma resina, três tipos de micropartículas: silanisadas, não silanisadas e tratadas com um silano não funcional. O estresse de contração gerado por esses materiais foi medido pela polimerização dos mesmos entre pratos de vidro montados em uma máquina de ensaios. A força máxima foi registrada 15 minutos após foto iniciação. Os resultados mostraram que, na resina, a adição de micropartículas tratadas com um silano não funcional reduziu em 50\% o estresse de polimerização, enquanto que a adição de micropartículas não silanisadas não reduziu o estresse. Na resina composta de partículas pequenas, a inclusão de micropartículas não silanisadas produziram uma redução de $30 \%$ quando comparadas com as micropartículas silanisadas, enquanto que as micropartículas tratadas com um silano não funcional não reduziram o estresse de contração. Afirmaram que a contração de polimerização de resinas compostas dentais podem transmitir altos níveis de estresse às superfícies dentais às quais estão aderidas e que essa contração pode levar a falha na formação de uma ligação adesiva com a superfície dental. Micropartículas que não são aderidas à 
matriz resinosa podem proporcionar sítios para alívio dos estresses internos, reduzindo o estresse de contração das resinas compostas.

Nesse mesmo ano TOLIDIS; NOBECOURT; RANDALL ${ }^{78}$ verificaram a contração de polimerização volumétrica de resinas compostas quando associadas ou não ao uso de cimento de ionômero de vidro modificado por resina como material intermediário. Foi observada uma redução de $41 \%$ na contração de polimerização do sistema restaurador quando o cimento de ionômero de vidro foi utilizado sob esse material restaurador. A provável explicação parece estar relacionada com a capacidade deste material de absorver as tensões geradas pela contração de polimerização. Isto se deve ao fato do baixo módulo de flexão da cadeia polimérica, recém-formada no cimento de ionômero de vidro modificado por resina, conferir uma matriz altamente flexível. A somatória desses fatores resulta em menor contração volumétrica de polimerização do compósito, uma vez que forramentos ionoméricos se mostram capazes de absorver parte das tensões geradas pela contração.

Ainda sobre a influência do módulo de elasticidade, SUH; CINCIONE; SANDRIK $^{73}$ (1998) avaliaram a relação entre o módulo de elasticidade do substrato, em cavidades experimentais, com o tipo de falha da restauração. Foi utilizada uma resina composta híbrida em cavidades preparadas em dente (esmalte e dentina), resina composta, porcelana e vidro. Foram preparadas cavidades classe I com dimensões de $3 \times 3 \times 3$ (fator- $C$ alto). Os resultados mostraram que os sistemas adesivos foram suficientes para resistir às forças de contração de polimerização da resina composta, porém, o alto módulo de elasticidade do substrato provocou falhas coesivas a uma curta distância da interface adesiva. O alto módulo de elasticidade do vidro (67GPa), porcelana (69GPa) e esmalte (85Gpa) determinaram falhas coesivas a poucos micrômetros da interface, porém o conjunto substrato/dentina adesivo permaneceu intacto. Os substratos com baixo módulo de elasticidade, como a dentina (18GPa) e a resina composta $(16 \mathrm{GPa})$, resistiram às tensões transmitidas. O autor concluiu que um 
substrato cavitário com baixo módulo de elasticidade é desejável em função da capacidade de deformação deste, entretanto, os substratos com alto módulo de elasticidade promovem falhas coesivas sob tensões de contração.

KORAN; KÜRSCHNER ${ }^{47}$, em 1998, realizaram um trabalho com o objetivo de verificar o efeito de iniciar a polimerização com luz de baixa densidade de potência seguido de um período de alta densidade de potência. Foram comparadas dureza superficial, adesão, contração, viscosidade e concentração de monômero residual (grau de polimerização) de corpos de prova polimerizados com irradiação variável ou contínua. Os resultados mostraram que a fotopolimerização em dois passos usando diferentes densidades de potência não modificou a contração, dureza superficial nem concentração de monômero residual quando comparada com a polimerização contínua. Os valores de adesão foram melhores para a técnica de dois passos quando comparados com a técnica contínua, amparando a teoria de que o escoamento do material é maior usando polimerização em dois passos, reduzindo o estresse de contração nas cavidades durante a polimerização preservando a integridade marginal. Os autores concluíram que a fotopolimerização seqüencial para resinas compostas provê adequado grau de polimerização e melhora a adaptação marginal por permitir maior escoamento do material durante os estágios inicias da polimerização.

Nesse ano, VERLUIS; TANTBIROJN; DOUGLAS ${ }^{82}$ realizaram um estudo no qual relataram que muitas das técnicas restauradoras com resinas compostas fotoativadas foram desenvolvidas em concordância com a teoria da contração em direção à fonte de luz das resinas. Entretanto, os autores afirmaram que não há suporte consistente na literatura para essa teoria. Com esse propósito utilizaram a metodologia de simulação de teste através de análise do elemento finito para observar a direção de contração de polimerização das resinas compostas químicas e fotoativadas. A análise mostrou que a direção de contração de polimerização não foi afetada significativamente pela orientação da fonte de luz, mas foi determinada principalmente pela adesão da restauração ao dente e pelas 
superfícies livres. Conseqüentemente, a diferença entre a contração das resinas auto e fotopolimerizáveis foi mínima. Os autores concluíram que as resinas compostas não contraem em direção à luz e, a direção de contração é determinada pelo desenho da cavidade e qualidade adesiva, sendo que a posição da fonte de luz não parece ser um fator influente para a melhoria da qualidade marginal.

Ainda em 1998, SAKAGUCHI; FERRACANE ${ }^{69}$ avaliaram a transferência de estresse de contração de polimerização de um corpo de prova de resina composta quimicamente ativada aderido a um substrato pré-fabricado de resina composta. Lâminas de tensão (strain gauges) foram aderidas na superfície da resina composta quimicamente ativada e na superfície da placa de resina composta com o intuito de medir a tensão por um período de 500 segundos. Os resultados mostraram que a tensão alcançou um patamar a partir dos 200 segundos depois de iniciada a mistura do material. A tensão continuou aumentando durante todo o período avaliado, porém a velocidade muito menor. Concluiu-se que a tensão foi realmente transmitida através da superfície adesiva nesta configuração experimental e que os resultados estiveram de acordo com trabalhos previamente publicados.

LÖESCHE ${ }^{52}$, em 1999, avaliou a adaptação marginal em restaurações de classe II com resina composta para determinar se a contração direcionada às paredes da cavidade, pela localização da fonte de luz, ou a redução da intensidade em função da passagem através da estrutura dental é responsável pela diminuição do estresse de polimerização. O autor concluiu que os bons resultados obtidos não deveriam ser atribuídos ao direcionamento da polimerização, mas sim à polimerização com baixa intensidade de luz.

Uma nova tecnologia para fotoativar resinas compostas na odontologia foi comentada por MILLS; JANDT; ASHWORTH ${ }^{57}$, em 1999. Consideraram que as fontes de luz halógenas apresentavam vários inconvenientes, entre eles, curta 
durabilidade das lâmpadas, pela degradação por altas temperaturas, e a conseqüente perda de intensidade luminosa. Destacaram que diodos que produzem luz (LEDs), como aqueles encontrados nos painéis dos carros, apresentam uma vida útil de 10,000 horas e, não apresentam uma degradação significante da intensidade luminosa durante esse período. Adicionalmente, os LEDs não requerem de filtros para se obter luz azul, são muito resistentes ao impacto e vibração e seu relativo baixo consumo de energia permitiria seu uso com baterias. LEDs de cor azul de baixa intensidade baseados na tecnologia de carburo de silício tem existido por vários anos, mas com uma intensidade de 7 uW. Recém em 1995, foram desenvolvidos LEDs a base de gálio, com intensidades de $3 \mathrm{~mW}$ e de cor azul. Segundo os autores, os primeiros trabalhos com mais de 60 LEDs com densidade de potência de apenas $100 \mathrm{~mW} / \mathrm{cm}^{2}$ mostraram a possibilidade de conseguir polimerizar adequadamente resinas compostas de uso odontológico. O propósito deste trabalho foi avaliar a profundidade de polimerização de uma fonte de luz LED e comparar os resultados com uma fonte de luz halógena com densidade de potência de $300 \mathrm{~mW} / \mathrm{cm}^{2}$. Os resultados mostraram que a fonte de luz LED apresentou maior profundidade de polimerização quando comparado com a fonte de luz halógena. Os autores fizeram uma aproximação matemática da equivalência entre a fonte de luz, halógena e LED, utilizada nesse trabalho. O fluxo total de energia irradiada pela fonte de luz halógena foi de $229 \mathrm{~mW}$, e para a fonte de luz LED de $82 \mathrm{~mW}$, isso representaria que a fonte de luz LED só representaria $36 \%$ do valor da halógena. No entanto, quando foi analisada a luz emitida numa freqüência entre 410-500nm, foi observado que a fonte de luz halógena apresentou $195 \mathrm{~mW}$ enquanto que a LED apresentou um valor de $78 \mathrm{~mW}$, representando o 40\% do valor da halógena. Esses dados também expressariam que $85 \%$ da luz emitida pela fonte de luz halógena estaria dentro dessa faixa, enquanto que a luz emitida pelos LEDs chegaria a 95\% dentro da mesmo comprimento de onda. Quando foi convertido para densidade de potência, a fonte de luz halógena com ponta de $8 \mathrm{~mm}$ alcançou $455 \mathrm{~mW} / \mathrm{cm}^{2}$, enquanto que a fonte de luz LED com ponta de $6 \mathrm{~mm}$ alcançou 290 $\mathrm{mW} / \mathrm{cm}^{2}$. Considerando a percentagem de luz emitida dentro da faixa de 410- 
500nm, seriam observados valores de $388 \mathrm{~mW} / \mathrm{cm}^{2}$ e $276 \mathrm{~mW} / \mathrm{cm}^{2}$ para a fonte de luz halógena e LED respectivamente. Segundo os autores a percentagem de energia útil para polimerizar a canforoquinona da fonte de luz LED avaliada representa $70 \%$ do valor da fonte de luz halógena avaliada, porém a distribuição espectral dentro desse comprimento de onda é diferente para as duas fontes de luz. Enquanto a fonte de luz LED apresenta uma concentração de fótons bastante grande perto dos 460nm, a fonte de luz halógena apresenta fótons de comprimentos de onda mais dispersos dentro dessa faixa. Segundo os autores, esse é um comportamento esperado, desde que os LEDs produzem luz a partir de um processo de eletroluminosidade, ou a recombinação radiativa de um elétron e um espaço dentro de um semicondutor p-n para produzir fótons. As características físicas do semicondutor determinam o comprimento de onda dos fótons. Os autores concluíram em função das características da luz emitida pela fonte de luz LED, que, mesmo a menor densidade de potência, esta poderia ser utilizada na polimerização de resinas de uso odontológico.

Ainda em 1999, RUEGGEBERG ${ }^{64}$ descreveu diversos métodos de polimerização das resinas compostas. Relatou que o componente fotoabsorvente mais comum utilizado nos materiais restauradores é a canforoquinona (CQ), que absorve energia dentro do espectro de luz visível azul entre 450 e 500 nm, com pico aproximadamente em $465 \mathrm{~nm}$. Quando excitada nessa energia, a canforoquinona colide com a amina formando um radical livre que forma ligações covalentes com as moléculas de dupla ligação carbônicas dos monômeros, formando uma reação em cadeia, polimerizando o material. A diminuição da intensidade de luz, à medida que a profundidade do material aumenta, constitui um problema que deve ser compensado com um aumento da duração da exposição da resina à luz, ou com aumento da intensidade de luz para maior excitação das moléculas. Relatou que os metacrilatos utilizados na composição dos materiais a base de resina promovem contração de polimerização do material que constituem. Com a adição de maior quantidade de carga às resinas, os fabricantes reduziram a contração volumétrica para 1,5 a 3\% que, entretanto, 
ainda pode resultar em transmissão de estresse às paredes cavitárias levando à formação de fendas marginais e fraturas do esmalte com a conseqüente sensibilidade pós-operatória. Afirmou que durante a fase inicial da polimerização, onde os polímeros encontram-se ainda flexíveis e em estado fluido, o estresse da contração pode ser aliviado pelo escoamento da resina e não há transmissão do estresse para a interface dente/resina. Quando o polímero aumenta sua rigidez (maior módulo de elasticidade) o estresse atinge a estrutura dental. O ponto no qual o polímero adquire um módulo de elasticidade suficiente para transferir o estresse para a interface dente-resina é chamado de ponto gel. Ainda comentou que ao diminuir a intensidade de luz nos instantes iniciais da polimerização, esta ocorre lentamente, gerando menor estresse, conseqüência do maior tempo que o material teria para escoar - essa técnica é conhecida como "soft-start". Quando o material atinge o estado gel, é submetido à alta intensidade de luz, garantindo grau de conversão equivalente ao obtido com a técnica convencional. Finalmente observou que, com a polimerização ocorrendo mais lentamente, as propriedades físicas dos polímeros são melhoradas, pois cadeias mais longas e com maior peso molecular são obtidas.

SAKAGUCHI ${ }^{67}$, esse mesmo ano, afirmou que a contração de polimerização dos compostos dentais é o maior responsável pela sensibilidade da técnica quando esses materiais são utilizados clinicamente. Relatou que as dificuldades com os contatos proximais, integridade marginal, espaços internos, sensibilidade pós-operatória e estabelecimento da oclusão, estão todos relacionados com a contração de polimerização. A contração é inerente aos sistemas atualmente disponíveis e persistirá até o surgimento de polímeros com baixa ou nenhuma contração. Portanto, o entendimento da origem e magnitude do estresse de contração é útil para proporcionar procedimentos clínicos racionais durante a inserção das resinas. Explicou que durante a polimerização há uma irreversível transformação de um líquido viscoso para um gel visco-elástico, no chamado de ponto de geleificação. Nos sistemas fotoativados a geleificação 
ocorre poucos segundos após a exposição à luz. Relatou que a contração que ocorre antes da geleificação é chamada de pré-gel e aquela que ocorre após a geleificação é chamada de pós-gel, sendo esta última de maior importância clínica, pois forças são transferidas desde a resina, através dos adesivos, para o esmalte e a dentina. Descreveu métodos utilizados para a medição do estresse de polimerização das resinas, afirmando que não é possível medir o estresse diretamente, e que a força da contração necessita ser transferida para um segundo corpo. Finalmente afirmou que alguns métodos medem a contração pósgel, mas não está claro se esses métodos captam toda a deformação pós-gel, e que os clínicos deveriam ser cautelosos em usar os valores de estresse como indicador de sucesso clínico de alguma marca de resina em particular sem o conhecimento das condições do teste efetuado.

SUH $^{71}$, também em 1999, relatou que a contração de polimerização das resinas compostas induz estresse na restauração final quando a resina está aderida à estrutura dental. Afirmou que a quantidade de estresse pode ser controlada pela técnica de polimerização de pulso tardio. Propôs que a embalagem das resinas indique: (1) a energia total requerida; (2) especificações da polimerização; (3) o espectro necessário na emissão de luz da lâmpada de polimerização.

Ainda em 1999, NAGEL ${ }^{60}$, em uma revisão dos fatores que afetam a fotoativação relatou que a intensidade de luz dentro de um comprimento de onda é medida pelo número de fótons emitidos, e que a energia de um fóton individual é ditada pela sua localização no espectro eletromagnético, e a sua habilidade em interagir com um material é determinada por essa energia individual. A capacidade de um fóton interagir, quando emitido a $470 \mathrm{~nm}$, é a mesma tanto para $100 \mathrm{~mW}$ como para $2000 \mathrm{~mW}$, embora existam vinte vezes mais fótons no mesmo tempo de emissão para o segundo caso e a absorção esperada seja vinte vezes maior. Afirmou que a energia e o comprimento de onda são funções inversas, e que na seleção de lâmpadas de polimerização, o espectro de emissão da unidade e a 
densidade de potência devem ser considerados, em função do espectro de emissão ter que coincidir com o espectro de absorção do compósito.

UNTERBRINK; LIEBENBERG ${ }^{80}$ afirmaram em uma revisão da literatura sobre resinas fluidas, que a odontologia adesiva poderia ser entendida como o simples relacionamento entre adesão e estresse, e que os fatores relacionados com o estresse de contração seriam, em ordem de importância: geometria da cavidade (fator de configuração e tamanho da cavidade), técnica de aplicação (camadas de resina e posição de luz) e material restaurador (módulo de elasticidade e mudanças dimensionais). Relataram que os adesivos com carga oferecem vantagens, pois a espessura da camada seria suficiente para eliminar o problema da inibição pelo oxigênio e causariam pouco estresse de contração em função de um fator de configuração favorável. Recomendaram o uso de resina composta fluida radiopaca associada a qualquer sistema adesivo para criar uma parede cavitária verdadeiramente elástica, considerando ser essa a chave para a obtenção de resultados clínicos aceitáveis.

VERLUIS; TANTBIROJN ${ }^{83}$ afirmaram, também em 1999, que a contração de polimerização dos materiais restauradores resinosos causam preocupações clínicas porque o estresse residual é transmitido para o dente restaurado. Esse estresse pode, entre outras coisas, causar fraturas do esmalte, microinfiltração marginal e sensibilidade pós-operatória. Relataram que a quantidade do estresse de contração não depende somente de quanto o compósito contrai, mas também do módulo de elasticidade do compósito, da forma da cavidade e da adesão estabelecida entre o dente e a restauração. Afirmaram que a relação entre esses fatores pode ser descrita por leis físicas, e que para analisar o estresse de contração, modelos teóricos deveriam ser usados para poder relacionar várias propriedades da contração com diferentes condições clínicas através das leis físicas e, assim, os modelos teóricos poder-nos-iam ajudar a repensar e otimizar os caminhos para o sucesso clínico. Relataram três definições que descrevem a contração: a quantificação (contrações volumétrica e linear), a fase (pré-gel, pós- 
gel e a contração total) e a distribuição (contração uniforme e não uniforme). Finalmente, descreveram que, para entender o problema de contração das restaurações dentais, é importante perceber que duas mudanças físicas maiores ocorrem durante a polimerização da resina: a solidificação e a contração, e que a interação entre ambos fenômenos causa o estresse de contração, que individualmente eles não causariam.

Ainda em 1999, LABELLA et al. ${ }^{50}$ estudaram a contração de polimerização e elasticidade tanto de resinas fluidas como de adesivos com carga inorgânica. Os resultados mostraram que as resinas fluidas apresentam menor módulo de elasticidade que as resinas híbridas e similar às resinas de micropartículas e os adesivo com carga. Em relação à contração de polimerização, as resinas fluidas apresentaram maior contração volumétrica que as resinas compostas híbridas e de micropartículas, e menor que os adesivos com carga. Os autores acrescentaram que o menor módulo de elasticidade e a maior contração volumétrica apresentada pelas resinas fluidas em relação às resinas híbridas e de micropartículas é uma evidencia indireta que a fluidez desses materiais é conseguida através do incremento da proporção de monômero na formulação da pasta resinosa. Observando os resultados obtidos com Aelite flo, Glaze, Durafill Flow e o adesivo Solid Bond, onde a relação inversa entre a contração de polimerização e o módulo de elasticidade não foi muito evidente, comentaram que possivelmente nessas resinas tenha-se utilizado monômeros de menor contração e mais flexíveis, levando os resultados a uma análise mais complexa que a simples relação matriz-carga. Finalmente concluíram que entre os materiais avaliados, as resinas fluidas e as resinas compostas híbridas se encontram em extremos opostos em relação aos valores de contração de polimerização e módulo de elasticidade. Enquanto as resinas fluidas foram os materiais com maior contração de polimerização e maior flexibilidade, as resinas compostas híbridas apresentaram um comportamento oposto. A magnitude e cinética da contração de polimerização junto com o módulo de elasticidade, podem ser de utilidade na predição de falhas adesivas. 
Preocupado com o comportamento das resinas fluidas PAYNE IV $^{61}$ pesquisou o selamento de restaurações classe II realizadas com resina fluida (Tetric Flow) como material intermediário e comparou os resultados com aqueles obtidos com cimento de ionômero de vidro modificado com resina (Fuji II LC) na margem proximal cervical. Foram confeccionadas 30 cavidades em pré-molares extraídos, onde foram realizadas restaurações com adesivo e resina fluida (grupo I), adesivo e ionômero de vidro (grupo 2) e ionômero de vidro sem adesivo (grupo 3). Todos os espécimes foram imersos em uma solução ao $2 \%$ de fucsina básica por 24 horas. Após terem sido seccionados foi observado o grau de infiltração nos diferentes grupos. Foi verificada diferença estatisticamente significativa entre os grupos 1 e 2 em favor do primeiro, entre 1 e 3 em favor do grupo 1e entre 2 e 3 em favor do grupo 2. O autor concluiu que a utilização de resina fluida e adesivo aparece como alternativa na diminuição da microinfiltração em cavidades proximais de classe II.

Ainda em relação à utilização de materiais intermediários em restaurações de resina composta, DIETRICH et al. ${ }^{33}$ avaliaram a adaptação marginal de restaurações diretas de classe II de resina composta comparando a técnica de condicionamento total, uso de forramento e técnica sanduíche. Observaram que restaurações realizadas com a técnica de condicionamento total ou com utilização de cimento de ionômero de vidro como forramento apresentaram grande porcentagem de margens abertos enquanto que a técnica sanduíche, onde o cimento de ionômero de vidro ou compómero foram colocados em toda a caixa proximal até a altura da parede oclusal conseguiram melhorar a qualidade de margens na área crítica na parede cervical. Os autores concluíram que em restaurações grandes com margem cervical em dentina, as restaurações de resina composta em conjunto com adesivos ou em combinação com um forramento de ionômero de vidro apresentam pobre adaptação marginal. A técnica sanduíche 
realizada com cimento de ionômero de vidro modificado com resina ou compómero pode melhorar a adaptação marginal desse tipo de restaurações.

Ainda em 1999, KINOMOTO et al. $^{46}$ compararam a distribuição e magnitude do estresse de contração entre uma resina quimicamente ativada e uma fotoativada. O estudo foi realizado utilizando análise de fotoelasticidade. Foi observado que a distribuição do estresse principal e o estresse gerado na parede da cavidade foi semelhante em resinas compostas quimicamente ativadas e fotoativadas. No entanto, quando a magnitude do estresse foi avaliada, observouse que a resina fotoativada gerou valores significativamente maiores, quando comparado com a resina quimicamente ativada. Os autores concluíram que a diferença na magnitude do estresse não estaria em função de sua distribuição, e que a velocidade de polimerização aparece como principal fator na magnitude de estresse interno durante a contração de polimerização.

Em 2000, CONDON; FERRACANE ${ }^{23}$ realizaram um estudo com o objetivo de medir a magnitude das forças de contração de polimerização de diversos materiais odontológicos resinosos e avaliaram o efeito de um monômero, recentemente lançado, e que é derivado de um metacrilato álcool estireno-alil, ou MSAA, na redução dessas forças. Os autores testaram onze resinas compostas existentes no mercado e uma série de resinas compostas experimentais em uma máquina de ensaios para medir a tensão máxima gerada. Os resultados mostraram relação significativa entre maior volume da matriz e aumento das forças de contração de polimerização. A introdução do MSAA reduziu em $30 \%$ as forças de contração das resinas experimentais, mostrando que monômeros com menor contração de polimerização induzem menores forças de contração, melhorando o prognóstico da interface adesiva. 
DAVIDSON $^{26}$, esse mesmo ano, relatou que, para iniciar a reação de polimerização de resinas compostas fotoativadas, a ativação da canforoquinona é essencial e pode ser obtida pela irradiação de luz azul com $470 \mathrm{~nm}$ de comprimento de onda. Afirmou que, para uma ótima conversão da resina, a energia pode ser suprida de diversas maneiras e é dependente das características da fonte de luz e do tempo de irradiação, sendo que para a prática odontológica uma combinação de baixo tempo de irradiação, grau de conversão alto e uniforme e baixo estresse de contração são o desejado. Afirmou que, uma conversão rápida é acompanhada de tensão que pode afetar negativamente a integridade marginal da restauração adesiva, existindo o paradoxo que tudo o que fazemos para melhorar o grau de conversão contribuirá negativamente para a preservação da continuidade marginal. Enfatizou que nas áreas profundas da restauração a energia é atenuada e, portanto, a completa conversão pode estar em risco. Relatou que, prolongar o tempo de irradiação é mais efetivo para conversão adequada do que o aumento de densidade de potência, mas que a utilização de uma fonte de luz confiável com saída de densidade de potência conhecida é recomendada. Finalizou afirmando que a qualidade marginal da restauração é garantida pela adequada seleção do material e a manipulação da energia de irradiação.

Uma revisão sobre as técnicas e aparelhos de fotoativação com especial ênfase na eficácia de polimerização e a conseqüente contração foi publicada por DAVIDSON; DE GEE ${ }^{30}$, ainda o ano 2000. Destacaram que para iniciar a polimerização da maioria de resinas compostas fotoativadas, a ativação da canforoquinona é essencial. Isto pode ser conseguido através da irradiação do material com luz de comprimento de onda específico. Para ótima conversão da resina, certa quantidade de energia é requerida. A energia pode ser aplicada em uma variedade de formas, sendo dependente das características da luz e do tempo de aplicação. Os autores mencionaram que um tempo prolongado de irradiação é mais efetivo para uma conversão adequada que aumentar a 
intensidade da energia. Finalmente afirmaram que desde que a manipulação da luz requer profundo conhecimento sobre o controle do estresse em restaurações adesivas, uma boa qualidade marginal poderia ser mais fácil de se obter, utilizando bases flexíveis que possam agir absorvendo estresse.

Ainda nesse ano, GORACCI ${ }^{39}$ afirmou que a contração de polimerização é um processo com duas fases: a fase pré-gel e pós-gel. Na fase pré-gel, a contração pode ser compensada pelo escoamento da resina composta, enquanto a contração da fase pós-gel não pode ser compensada, transmitindo tensões que podem levar a falhas nas paredes cavitárias. Mencionou que o objetivo da polimerização progressiva, com intensidade baixa inicial e posteriormente alta, é compensar essa contração procurando dilatar a fase pré-gel permitindo melhor adaptação interna da resina, proporcionando melhor qualidade da interface denteresina.

SUH $^{72}$ citou que a contração é uma propriedade física conseqüência de uma reação química, e é inerente ao material restaurador. Afirmou que as resinas compostas apresentam matriz orgânica que contrai $10 \pm 2 \%$ em volume, e de carga inorgânica que não contrai. Relatou que, quanto mais carga é adicionada ao material, menor será a contração da resina composta resultante. Porém isto não significa que toda resina com baixa contração, necessariamente gera baixo estresse, em função do aumento do módulo de elasticidade da mesma com o aumento de carga inorgânica. Afirmou, ainda, que a técnica de polimerização conhecida como pulso tardio reduz, mais do que qualquer outra técnica, 0 estresse de contração, pois aumenta de uma maneira eficiente a fase pré-gel da resina, onde o material pode escoar e aliviar o estresse de contração.

CHOI; CONDOM ${ }^{20}$ comentaram que as resinas compostas apresentam ainda algumas propriedades não desejadas que podem afetar sua durabilidade 
como material restaurador. Uma delas, segundo os autores, é a contração que inevitavelmente acontece quando o material polimeriza e troca a distância de Van der Whaals entre suas moléculas por uma distância de ligação covalente. Essa contração pode transmitir estresse quando o material é confinado dentro de uma cavidade adesiva. Uma forma prática que estaria sendo utilizada para diminuir as conseqüências de esta contração é o uso de camadas de maior espessura de adesivo como camada intermediária entre a resina composta e o dente. Uma camada de espessura considerável de material de baixo módulo de elasticidade poderia absorver parte do estresse de contração gerado pela resina composta durante sua polimerização. Assim, o propósito deste estudo foi avaliar e medir quantitativamente o estresse de contração de uma resina composta variando a espessura do adesivo, e relacionar esse efeito com a microinfiltração em cavidades de classe $V$ preparadas em dentes bovinos. A montagem do teste foi semelhante àquela descrita por FEILZER; DE GEE; DAVIDSON ${ }^{34}$. A força de contração foi registrada durante 15 minutos e o valor máximo nesse período foi considerado. Foram avaliados 30 corpos de prova, nos quais a espessura do adesivo variou de 20 a 300um, em cavidades de fator-C 2 e 3. Para o teste de microinfiltração foram utilizados 24 dentes bovinos extraídos onde foram preparadas cavidades de classe $\mathrm{V}$ semelhantes entre elas, separadas em dois grupos, com fator-C 2 e 3. O adesivo utilizado foi o Scotchbond MP. Os resultados mostraram que existiu diminuição de $17 \%$ no estresse de contração quando o corpo de prova passava a utilizar duas camadas de adesivo no lugar de uma única camada. Quando passou a utilizar três camadas apresentou diminuição adicional de $13 \%$, em cavidades de fator-C 2 . Em cavidades de fator-C 3, a utilização de duas camadas promoveu a diminuição de aproximadamente $24 \%$ no estresse de contração, enquanto que uma terceira camada não promoveu beneficio algum. A diminuição de estresse de contração produzida pelo adesivo tem sido relacionada com seu baixo módulo de elasticidade tanto nele mesmo como na área de interdifusão com a dentina. Esse estudo demonstrou que o estresse transmitido durante a polimerização da resina composta foi significantemente reduzido pela aplicação de espessuras maiores de adesivo. Foi observado que a aplicação de 
uma camada adicional de adesivo aumenta a espessura da camada deste de duas a quatro vezes. Adicionalmente, o estresse foi positivamente relacionado com a microinfitração precoce da restauração. Desta forma, segundo os autores, aumentar a espessura do adesivo pela utilização de camadas adicionais poderia levar a melhor adaptação marginal e conseqüentemente aumentar a vida útil da restauração.

Ainda em 2000, YAP et al. $^{85}$ avaliaram as mudanças dimensionais em longo prazo em uma resina composta convencional e uma resina modificada por poliácidos (compómero), e verificaram o efeito da hidratação sobre a contração de polimerização. Foram utilizadas lâminas de tensão (strain gauges) para medir a contração linear em cada material em água a $37^{\circ} \mathrm{C}$ ou no ar a $26^{\circ} \mathrm{C}$ durante um período de um mês. Os resultados mostraram que a reação de polimerização de ambos, a resina convencional e modificada por poliácidos, é acompanhada por uma mudança dimensional. A velocidade de contração foi para ambos materiais, maior durante a fotoativação, e continuou mesmo depois de ter concluído esse procedimento. Quando foram armazenadas em água, a maior contração foi registrada depois de uma hora para ambos materiais. Isto foi seguido por uma lenta absorção de água e expansão em um período de um dia a um mês. A resina modificada por poliácidos apresentou contração final significativamente menor que a resina convencional depois de um mês de armazenamento em água.

Interessados em entender o comportamento viscoelástico dos materiais dentários, DAUVILLIER et al. $^{24}$ (2000) estudaram algumas propriedades do processo de endurecimento, tanto em uma resina composta quimicamente ativada como em um cimento de ionômero de vidro convencional. Os autores ressaltaram que o estresse de contração de polimerização é ainda um dos maiores problemas na odontologia adesiva, desde que geralmente promove a perda da adesão do material às paredes da cavidade e a formação de fendas marginais. A velocidade de formação de estresse e o estresse máximo dependem do comportamento 
viscoelástico dos materiais dentários durante seu endurecimento. O propósito desse estudo foi determinar o comportamento do módulo de elasticidade e viscosidade durante o processo de endurecimento desses materiais. Com esse propósito foi utilizada uma metodologia mecânica dinâmica, de forma que os materiais foram submetidos a tensão cíclica e periódica durante os primeiros 60 minutos do endurecimento. Foi observado que, tanto módulo de elasticidade como viscosidade foram desenvolvidos rapidamente no material resinoso, em quanto que no cimento ionomérico estes se mantiveram quase constantes. A liberação de estresse é uma propriedade importante dos materiais, e envolve a diminuição gradual do estresse a uma tensão constante através do escoamento do material. Os resultados deste trabalho mostraram que o cimento de ionômero de vidro poderia ser mais eficiente que as resinas compostas em reduzir o estresse de contração através do escoamento do material nas suas superfícies livres. O estresse de contração durante os primeiros 15 minutos seria menor, possibilitando que a adesão seja formada adequadamente e seja mantida intacta, enquanto a rigidez final do cimento é alcançada.

Em 2001, CHEN et al. $^{18}$ estudaram o estresse de contração de polimerização de resinas compostas fotoativadas condensáveis. Foram avaliadas 4 resinas compostas condensáveis (Solitaire, Solitaire 2, Surefil, Alert) um ormocer (Definite) e uma resina composta híbrida (Tetric Ceram). Foi utilizada uma máquina de ensaios montada especificamente para registrar as tensões geradas durante a contração de polimerização. As dimensões do espécime de resina composta foram $4 \times 4 \times 2 \mathrm{~mm}$ com um fator " $C$ " de 0.33. As resinas foram polimerizadas de modo convencional com densidade de potência de $800 \mathrm{~mW} / \mathrm{cm}^{2}$. Foi observado que todas as resinas compostas transmitiram estresse desde 0 início da fotoativação e durante todo o período avaliado (300seg.). Alert e Definite (4.60 e 4.16 Mpa respectivamente) mostraram valores significativamente maiores que os outros materiais avaliados. Não existiu diferença significativa entre Solitaire (3.33 Mpa), Solitaire 2 (3.36 Mpa) e Surefil (3.13 Mpa). Tetric Ceram mostrou menores valores que todos os materiais (2.51Mpa). A diferença foi atribuída ao 
diferente módulo de elasticidade dos materiais avaliados. Ainda foi observado que a força de contração foi gerada a diferente velocidade para diferentes materiais, existindo relação direta com os valores máximos de forças de contração. Foi verificada a existência de um incremento da velocidade com que a forca foi gerada, imediatamente depois do final da fotoativação. Os autores explicaram que esse incremento rápido da contração pode ser conseqüência da diminuição da temperatura quando a fonte de luz é desligada. Finalmente concluíram que as resinas condensáveis geraram forças significativamente maiores que a resina híbrida.

DAVIDSON $^{27}$, esse mesmo ano, relatou que as necessidades de um material restaurador para apresentar propriedades satisfatórias são complexas, e estão relacionadas com o domínio da biocompatibilidade e da estética. Escreveu que características mecânicas apropriadas são requisitos essenciais e que, graças ao mecanismo de adesão, restaurações são praticamente fusionadas à estrutura dental remanescente, o que contribui significativamente para a longevidade do dente restaurado. Citou que os materiais a base de resina requerem profundo entendimento do processo de adesão e da criação de estresse. Afirmou que o cimento de ionômero de vidro tem a capacidade de liberar flúor nas margens das restaurações e de estimular a hipermineralização das estruturas dentais adjacentes. Afirmou, ainda, que o processo de contração de polimerização do cimento de ionômero de vidro é menos destrutivo para a adesão do que o das resinas compostas, em função de que durante a fase inicial de polimerização o ionômero de vidro se apresenta como uma borracha o que permite redução de volume de forma mais elástica e menos rígida do que na fase inicial da polimerização da resina. Explicou que outro fator que contribui para a compensação da contração é a baixa força coesiva do ionômero que pode gerar microfraturas internas. 
O mesmo pesquisador citou em outro trabalho ${ }^{28}$, que para se trabalhar com resinas compostas e cimentos de ionômero de vidro modificado por resina, o profissional deveria conhecer profundamente as características desses materiais, tais como sua composição, estrutura e iniciação da reação de polimerização. Afirmou que a iniciação pode ser alcançada pela ativação do iniciador, adicionando ao sistema energia em forma de luz visível, e que para esse propósito o dentista tem que selecionar uma fonte de luz diante das várias opções e das diferentes filosofias, como a luz halógena, o arco de plasma, o laser ou as fontes de luz de LED, com níveis de densidade de potência que variam de 350 até acima de $1000 \mathrm{~mW} / \mathrm{cm}^{2}$. O objetivo é obter conversão alta e uniforme em tempo tão curto quanto possível de irradiação, uma profundidade avançada, com baixo estresse de contração de polimerização, para resultar em uma restauração durável. Afirmou que uma das formas de reduzir o estresse de contração seria utilizando baixa densidade de potência inicial, para promover uma reação de polimerização mais lenta e com menor módulo de elasticidade inicial. Concluiu que a utilização de fontes de luz de alta densidade de potência, gerando uma rápida conversão, é acompanhada de rápida rigidez e transmissão de estresse de polimerização, que pode afetar a integridade marginal das restaurações adesivas.

MIGUEL; DE LA MACORRA ${ }^{56}$ (2001) propuseram uma fórmula matemática associando o estresse de contração de polimerização em relação às superfícies livres e aderidas da cavidade, o volume do material e a deformação de materiais resinosos. Os autores criticam a metodologia de FEILZER; DE GEE; DAVIDSON $^{34}$ expondo algumas limitações na montagem do ensaio. Explicam que o sistema de reposicionamento usado nesse estudo só reconhece a mudança de distância entre as bases e a repõe, gerando movimento para, em teoria, manter a distância constante. Segundo os autores, esse não pode ser considerado um sistema rígido, desde que as bases estão continuamente aproximando-se em decorrência das tensões produzidas pelo material durante a polimerização e afastando-se em função do sistema de reposicionamento. Para eles, esse 
contínuo movimento de bases poderia induzir a leituras errôneas, desde que poderia ser possível que o material seja parcialmente estressado. Outra limitação, segundo os autores, é mais de origem conceptual. Não existe um sistema totalmente rígido na natureza, e os dentes e a restauração inevitavelmente possuem uma certa capacidade de deformação, que permite que as tensões sejam parcialmente relaxadas. Também critica o fato de que o fator $C$ não considere volume da restauração, nem as características específicas do material. Avaliaram corpos de prova cilíndricos de 9 materiais quimicamente ativados. Os diâmetros dos discos foram 5,81; 8,5; 11,26; 12,42; 17,02 e 23,14 mm com alturas de 0,02 e 5,9mm. Foram deixados polimerizar por um período de 25 minutos. Os resultados mostraram que não existiu uma relação linear direta entre o fator $\mathrm{C}$ e 0 estresse de contração. A maior fator $C$, menores foram as tensões achadas. Mesmo com resultados contrastantes, observaram que o modelo de FEILZER; DE GEE; DAVIDSON ${ }^{34}$ é até agora a melhor solução para medir o máximo estresse de contração, mas que não representa o que acontece na cavidade, onde parte do estresse é mascarada pelo movimento da estrutura dentária, relaxando tensões dos incrementos de resina composta, sugerindo finalmente a utilização de sistemas não rígidos, que considerem a deformação do sistema para avaliar o estresse de polimerização. Os valores que acharam $(0,05$ até $0,6 \mathrm{Mpa})$ foram menores que valores publicados em trabalhos prévios. Novamente, enfatizaram que isso estaria em função da deformação do modelo não rígido. Ainda os autores sugerem que a influência da superfície aderida não é necessariamente a mesma que a da superfície livre, e postula que esta última poderia ser maior, tornando o volume um fator importante. Finalmente sugerem que a utilização de corpos de prova cilíndricos montados entre duas bases para a interpretação da situação clínica (cavidades) poderia ser um erro, sugerindo que corpos de prova com forma de cavidades reais deveriam ser usados.

TESSORE; TRINCHERO ${ }^{77}$, em 2001, realizaram um trabalho sobre a sensibilidade pós-operatória como conseqüência de restaurações de resina 
composta em dentes posteriores. Relataram que a sensibilidade pós-operatória seria o resultado de um selamento imperfeito ao nível de dentina, esmalte ou ambos, e que as razões para esse selamento imperfeito estariam relacionados com a impregnação imperfeita do sistema adesivo sobre o substrato dentinário ou pelas forças de contração de polimerização que podem causar microfraturas na estrutura de esmalte ou descolamento da resina composta da estrutura dental. Explicaram que, durante a polimerização, as resinas compostas estão sujeitas a uma redução volumétrica de 2 a 6\%, e que essa redução exerce uma força de 8 a $23 \mathrm{MPa}$ nas paredes da cavidade, dependendo do tipo de resina e da forma da cavidade, podendo causar o aparecimento de fendas, pela separação do adesivo das estruturas dentinárias, ou microfraturas da estrutura do esmalte. Afirmaram ainda que, teoricamente, um compósito com alta concentração de carga tem uma menor contração de polimerização, mas, paradoxalmente ele pode gerar maior estresse por ser menos elástico e possuir menor capacidade de escoar para compensar a contração. Assim, recomendaram a utilização, na prática clínica, de base com material altamente elástico após a camada adesiva para reduzir o estresse transmitido às estruturas dentárias. Recomendaram, ainda, a utilização de selantes de superfície para eliminar as porosidades da resina, fendas na interface dente-restauração e microfraturas de esmalte, reduzindo assim a sensibilidade pós-operatória.

Nesse mesmo ano BEZNOS ${ }^{6}$, também preocupado pela eventual microinfiltração de restaurações estéticas de classe II, avaliou diferentes técnicas restauradoras combinando a restauração de resina composta com diferentes materiais intermediários. Assim, o grupo 1 foi restaurado utilizando a técnica de condicionamento ácido total, adesivo e a aplicação da resina composta de forma incremental; o grupo 2 foi restaurado utilizando a mesma técnica que o grupo anterior, só que no primeiro incremento foi utilizada uma resina quimicamente ativada; no grupo 3 foi utilizado um cimento de ionômero de vidro modificado por resina como incremento inicial, com uma espessura de $2 \mathrm{~mm}$ na parede gengival, 
na técnica de sanduíche aberta; o grupo 4 recebeu na parede gengival a aplicação de resina fluida, em um incremento inicial de $2 \mathrm{~mm}$ de espessura, para depois receber a resina composta fotoativada. Todos os espécimes foram submetidos a ciclagem térmico antes de serem imersos em azul de metileno por um período de 24 horas. Os resultados mostraram diferentes comportamentos, sendo característico para o grupo 1 a ausência de microinfiltração na margem gengival em esmalte e extensa microinfiltração quando esta margem foi localizada em dentina. No grupo 2 obteve-se, maiormente, ausência de microinfiltração na margem gengival em esmalte e um valor moderado na margem cervical em dentina. Nas restaurações realizadas com cimento de ionômero de vidro modificado com resina como incremento gengival obteve-se predominantemente ausência de microinfiltração na margem gengival quando localizada em esmalte e o menor valor de microinfiltração entre os grupos avaliados na margem gengival localizada em dentina. Finalmente, o grupo restaurado com resina fluida como incremento inicial teve uma mediana incidência de ausência de microinfiltração quando a margem gengival foi localizada em esmalte, e altos valores de microinfiltração na margem gengival em dentina, porém a análise estatística não mostrou uma diferencia estatisticamente significativa entre os diferentes tratamentos. Essa diferença só foi significativa quando as margens foram comparadas. Os autores analisaram os resultados e discutiram sobre a vantagem e desvantagem de cada técnica chegando à conclusão que mesmo que várias técnicas tenham sido sugeridas para o selamento de cavidades de classe II restauradas com resina composta, nenhuma alcançou seu maior objetivo; eliminar completa e sistematicamente a microinfiltração nas margens de dentina ou cemento.

Esse mesmo ano HAGGE et al. ${ }^{40}$ observaram que aproximadamente $88 \%$ dos dentistas gerais realizavam routinariamente restaurações de resina composta, e que mesmo que a adesão ao esmalte tenha-se mostrado muito confiável, o mesmo não acontecia com a adesão à dentina e cemento. Ainda acrescentaram que apesar do rápido desenvolvimento dos adesivos dentinários nos últimos anos, 
a contração de polimerização ainda continua quebrando a adesão da resina ao dente, produzindo uma fenda quando as margens cervicais são extendidos na dentina. A microinfiltração através desta fenda pode levar à sensibilidade pósoperatoria e aumento do risco de cárie secundária. Algumas técnicas foram propostas no intuito de eliminar esta fenda, como a técnica incremental, as matrizes e cunhas transparentes, insertos de quartzo, utilização de resinas quimicamente ativadas, preparo de uma canaleta gengival, fotoativação programada e a técnica sanduíche com ionômero de vidro ou outro material como camada intermediária. Outros materiais restauradores que estão sendo propostos como camada intermediária incluem as resinas fluidas e compómeros. Segundo os autores, as resinas fluidas apresentam propriedades físicas fracas, quando comparadas com resinas híbridas, sofrem maior contração volumétrica, possuem maior coeficiente de expansão térmica e não são indicados para serem utilizados em áreas de alto estresse mecânico. Porém, no uso como camada intermediária, seu proposto mecanismo de reduzir a microinfiltração esta relacionado com sua relativamente alta elasticidade, que poderia compensar o estresse de contração de polimerização da resina composta restauradora final. Os autores se propuseram avaliar a microinfiltração de restaurações de resina composta utilizando só o material restaurador Sure Fil (grupo 1); uma camada intermediária de resina fluida Revolution (grupo 2); uma camada intermediária de compómero fluido Dyract Flow (grupo 3); uma camada intermediária de resina quimicamente ativada Bis Fil 2B (grupo 4) e uma camada intermediária de cimento de ionômero de vidro modificado por resina Fuji II LC (grupo 5). As margens da cavidade foram localizadas em dentina, $1 \mathrm{~mm}$ apical da junção amelodentinaria. O corante utilizado foi uma solução ao $0,5 \%$ de fucsina básica. Os espécimes foram submetidos à ciclagem térmica em temperaturas entre $5^{\circ} \mathrm{C}$ e $55^{\circ} \mathrm{C}$. Os resultados mostraram que o grupo 5 permitiu uma microinfiltração significantemente menor que os outros grupos, quando analisado estatisticamente. Todos os espécimes dos grupos 1 e 2 filtraram até a parede axial, extendendo-se em alguns casos através dos túbulos dentinários em direção pulpar. De maneira similar, a maioria dos espécimes dos grupos 3 e 4 filtraram até a parede axial (67\% e 75\% respectivamente), porém no 
grupo 3 apresentaram-se resultados com escore 0 e 1 em $25 \%$ dos casos, mostrando a maior variabilidade de todos os grupos avaliados. Os autores concluiriam que a utilização de uma camada de cimento de ionômero de vidro modificado por resina em cavidades de classe II quando a margem gengival é extendida até dentina é favorável em relação ao uso de adesivos dentinários em conjunto com outros materiais restauradores.

Ainda avaliando o efeito de materiais intermediários, ALOMARI; REINHARDT; BOYER ${ }^{1}$ (2001) estudaram a deflexão de cúspides e formação de fenda marginal em restaurações feitas com resina composta. Com esse propósito foram realizadas 40 cavidades em dentes extraídos, e separados em quatro grupos restaurados da seguinte forma: no grupo 1 foi restaurado com resina composta Z-100 como único material; no grupo 2 foi utilizada uma camada de resina fluida Revolution como material intermediário; no grupo 3 a camada intermediária foi realizada com cimento de ionômero de vidro Vitrebond e no grupo 4 foi aplicada uma camada de Z-100 antes de aplicar o adesivo, a maneira de material intermediário. Foi observado que o grupo 1 apresentou a maior deflexão de cúspides tanto no período de avaliação de 5 minutos quanto de 24 horas, enquanto que o grupo 3 apresentou os menores valores em ambos períodos. $O$ grupo restaurado com resina fluida como material intermediário foi melhor que os grupos 1 e 4 no período de 24 horas, porém pior que o grupo 3. A diferença dos valores dos períodos de 5 minutos e 24 horas foi atribuída à expansão higroscópica, elasticidade das estruturas dentárias e formação de fenda ou fratura dentária. Os autores comentaram que o estresse de contração de polimerização é transmitido à estrutura dentária quando uma boa qualidade adesiva é conseguida na interface dente-restauração. Como conseqüência, cúspides enfraquecidas podem-se movimentar até 15um durante os primeiros 15 minutos depois de realizada a restauração. O melhor comportamento observado com a resina fluida em relação aos grupos restaurados com resina composta foi atribuído ao baixo módulo de elasticidade da resina fluida. O mecanismo de ação seria a absorção de estresse de contração da resina composta através da flexibilidade do material. 
O mesmo aconteceria com o cimento de ionômero de vidro modificado com resina, onde a reação, e conseqüente contração, á mais lenta que nas resinas restauradoras, oferecendo oportunidade à adesão para ser formada. Em este estudo, a deflexão de cúspides, quando uma camada de cimento de ionômero de vidro modificado por resina foi utilizada, mostrou-se $50 \%$ e $43 \%$ menor que o grupo restaurado com resina composta, nos períodos de 5 minutos e 24 horas respectivamente. Os autores fizeram referência ao trabalho de LABELLA et al. ${ }^{\mathbf{5 0}}$ que verificaram que a resina fluida Revolution apresenta um módulo de elasticidade de 7,7 GPa e uma contração volumétrica de 5,5\% enquanto que a resina composta Z-100 apresenta um módulo de elasticidade de 20,1 GPa e uma contração volumétrica de $2,3 \%$. Segundo os autores, a contração volumétrica e o módulo de elasticidade promovem efeitos contrários sobre o estresse total que chega na estrutura dentária e causa a eventual deflexão das cúspides. A alta contração volumétrica apresentada pela resina fluida poderia explicar porque, mesmo com um módulo de elasticidade baixo, não foi tão eficiente em reduzir a deflexão de cúspides como o cimento de ionômero de vidro modificado com resina onde uma baixa contração de polimerização é acompanhada de um baixo módulo de elasticidade. Os autores concluíram que o uso de materiais intermediários reduz a deflexão de cúspides e que o ionômero de vidro modificado com resina é mais efetivo que a resina fluida.

Considerando que a resina contrai durante sua polimerização, e que os adesivos atuais podem em certas situações, resistir às tensões transmitidas pela resina composta SUH; WANG $^{74}$ avaliaram a direção desta contração para diferentes situações de adesão ao substrato. Foram utilizadas uma resina fotoativada e uma quimicamente ativada. Para simular a preparação de classe I, cada resina composta foi inserida em um anel de vidro com diâmetro interno de $3,2 \mathrm{~mm}$, diâmetro externo de $8,5 \mathrm{~mm}$ e altura de $3 \mathrm{~mm}$. Três condições adesivas foram testadas; grupo 1 testou a ausência de adesão a qualquer parede; o grupo 2 testou a adesão exclusivamente nas paredes de vidro; o grupo 3 testou a adesão às paredes e a um piso da cavidade feito de resina prepolimerizada. A resina 
composta fotoativadas foi inserida em cavidades com 3 fatores- $C$ diferentes $e$ duas técnicas de inserção (incremento único e incremental). Para cada uma das seis condições experimentais foram realizados 3 corpos de prova. Os resultados mostraram que, tanto nos corpos de prova com adesão às paredes, como naqueles grupos onde não existiu adesão às paredes, o material apresentou uma concavidade (deflexão céntrica em direção ao centro da massa) depois da polimerização. A magnitude dessa deflexão aumentou significantemente quando a quantidade de paredes adesivas aumentou. Os autores acrescentaram que nos grupos 1,2 e 3 a resina se afastou da fonte de luz. A maior deflexão aconteceu no centro do extremo superior do corpo de prova, mesmo que esse ponto tenha ficado mais perto da fonte de luz e conseqüentemente tenha sido o primeiro a receber a luz, confirmando as observações de VERLUIS; TANTBIROJN; DOUGLAS $^{82}$. Observaram que no extremo inferior do anel a concavidade foi maior. A explicação dos autores foi que a resina fotoativada que fica nesse extremo recebe menor intensidade de luz e a sua polimerização seria mais lenta, permitindo que a fase pré-gel seja mais extensa, e o ponto de geleificação demore mais em ser alcançado. Essas condições permitiriam maior possibilidade de compensar o estresse de contração através do fluxo na superfície livre, em comparação com a resina no extremo superior onde essa fase pré-gel é alcançada rapidamente. A maior fluxo, maior deformação do material, mas menor estresse residual. A resina quimicamente ativada mostrou o mesmo padrão de contração que a resina fotoativada. Esses resultados sugerem que a direção de contração tanto para as resinas fotoativadas como quimicamente ativadas estaria mais em função das paredes da cavidade e superfície livre que do tipo de resina composta. Em relação à técnica incremental, observaram que não existiu diferença estatisticamente significativa entre essas técnicas, sugerindo que o processo de fluxo do primeiro incremento deve ter sido suspendido em uma fase inicial da polimerização, pelo segundo incremento, não observando vantagem alguma na técnica incremental no aspecto avaliado. 
TAPETY ${ }^{76}$, em 2001, avaliou os níveis de microinfiltração em cavidades de classe II restauradas com três sistemas restauradores para dentes posteriores (P60/Single Bond-3M; Solitaire/One Bond-Kulzer e Surefil/Prime \& Bond 2.1=Dentsply, com interposição de bases (uma resina de baixa viscosidade; Flow it! (Jeneric Pentron); e um ionômero de vidro modificado por resina Vitremer-(3M)). Nos grupos controle nenhuma base foi utilizada. A margem cervical foi localizada na caixa mesial, $1 \mathrm{~mm}$ além do limite amelo-cementário, enquanto que na caixa distal a margem foi localizada $1 \mathrm{~mm}$ aquém do limite amelo-cementario. Menor microinfiltração foi observada quando as margens foram localizadas em esmalte, independentemente da utilização ou não de base. A presença de base não resultou em redução da infiltração marginal para as resinas P-60 e Surefil, independente da margem avaliada. A resina Solitaire apresentou os maiores níveis de infiltração quando empregada sem a presença de base. Assim, concluiuse que a presença de base pode minimizar os níveis de infiltração, nas margens em esmalte e dentina, porém está na dependência do sistema restaurador empregado.

Preocupados com o aumento no uso das resinas fluidas, no intuito de aproveitar seu baixo módulo de elasticidade para absorver parte do estresse de contração de polimerização da resina composta, MALMSTRÖM et al. ${ }^{54}$ estudaram o efeito da espessura da camada de resina fluida sobre a microinfiltração de restaurações de classe II de resina composta. Foram avaliadas três espessuras diferentes $(0,5 \mathrm{~mm}, 1 \mathrm{~mm}$ e $2 \mathrm{~mm})$ de resina fluida sobre a parede gengival de cavidades MO e OD. No grupo controle, as restaurações foram feitas com a mesma técnica, excluindo o uso de resina fluida sobre a parede gengival. Os dentes foram termociclados e submergidos em uma solução de $50 \%$ de nitrato de prata antes de serem seccionados para serem avaliados baixo microscópio ótico. Os resultados mostraram que a maioria das margens localizada em esmalte não apresentou microinfiltração, enquanto as margens de dentina mostraram o contrário. Na margem localizada em esmalte, existiu diminuição considerável de infiltração quando a espessura da resina fluida aumentou. Quando a margem foi 
localizada em dentina, a espessura da resina fluida não produziu nenhuma modificação significante em relação à microinfiltração. Os autores acrescentaram que a capacidade da resina fluida de reduzir a microinfiltração em restaurações com margem em esmalte pode ser associada à possibilidade deste material absorver tensões de contração em função do seu baixo módulo de elasticidade, que permitiria maior deformação plástica durante as fases iniciais da polimerização. Por outro lado, a maior contração volumétrica poderia atuar negativamente em relação ao selamento marginal especialmente quando a adesão é inadequada.

A influência da qualidade adesiva da interface sobre a direção da contração de polimerização foi avaliada por $\mathbf{C H O}$ et al. ${ }^{19}$, em 2002. Segundo os autores a forte adesão existente nos adesivos atuais poderia afetar a direção da contração de polimerização e mudar o conceito clássico da suposta contração das resinas fotoativadas em direção da fonte de luz e quimicamente ativadas em direção do centro da massa do material. Foi demonstrado que a presença de adesão influiu significantemente nos resultados, e que, para obter uma forte adesão com capacidade de enfrentar a força de contração de polimerização o adesivo deve ser polimerizado antes da inserção da resina composta. Outra observação importante nesse trabalho foi que a resina fluida apresentou piores resultados, produzindo maior deformação pela contração de polimerização. Os autores comentaram que esses resultados sugerem que a excessiva contração de polimerização desenvolvida pela resina fluida foi o suficientemente grande para ultrapassar a força de adesão, e que a flexibilidade do material não foi suficiente para compensar essa contração e seu correspondente formação de estresse. Finalmente sugeriram, em base a seus resultados, que a direção dos vetores de contração de polimerização foi para um centro localizado muito perto da superfície adesiva, porém a localização exata era dependente da qualidade desta, sendo que quando melhorava o centro para onde se dirigiriam os vetores de contração de polimerização ficava mais perto da interface adesiva. 
BRAGA; FERRACANE ${ }^{11}$, em 2002, avaliaram a influencia do grau de conversão final e velocidade de reação sobre o estresse de contração de polimerização em restaurações de resina composta. Os resultados mostraram que maiores tempos de exposição (similar densidade de potencia, porém maior densidade de energia) produzem maior grau de conversão. Como foi esperado, quando a resina composta foi irradiada com a mesma densidade de potência, porém por um tempo maior, os parâmetros mostrando a cinética da reação não mostraram diferença significante, demonstrando que a velocidade da reação foi a mesma nos grupos avaliados. O grau de conversão final foi o único responsável pela diferença nos valores de estresse de contração. Tanto o grau de conversão como a contração de polimerização não mostraram diferenças significativas após 60 segundos de ativação. Segundo os autores, acima de certo nível de densidade de energia, o grau de conversão e a contração não aumentam proporcionalmente com a densidade de energia, devido à mobilidade restringida dos radicais livres dentro da rede do polímero. As menores variações em grau de conversão e contração aconteceram no período de 60 a 120 segundos, no entanto, estes corresponderam a um maior aumento do estresse. Segundo os autores o aumento do módulo de elasticidade não permite ao material liberar tensões, sendo a causa para que pequenas mudanças no grau de conversão ou contração aumentem o estresse de contração.

Ainda em 2002, CASTAÑEDA-ESPINOSA; MONDELLI ${ }^{14}$ propuseram uma nova metodologia para avaliar as forças de contração na polimerização de resinas compostas ativadas com luz halógena e LED. Foram utilizadas duas bases de aço em forma retangular ( $6 \times 2 \mathrm{~mm})$, posicionadas paralelamente, sendo uma conectada ao braço móvel da máquina de ensaios (Emic - DL 500), através de uma célula de carga de $10 \mathrm{Kg}$, e outra ao braço fixo. As resinas compostas foram introduzidas entre as bases metálicas, com $1 \mathrm{~mm}$ de altura, volume de $12 \mathrm{~mm}^{3} \mathrm{e}$ fator $C$ 1,5. As bases ficaram fixas durante o ensaio, e as forças geradas durante a 
polimerização foram registradas através de uma curva força/tempo, num total de dez ensaios para cada grupo. As resinas compostas de micropartículas (A110, 3M), micro-híbrida (Z250, 3M) e condensável (P60, 3M) foram polimerizadas por 60 segundos com luz halógena (Dentsply - $500 \mathrm{~mW} / \mathrm{cm}^{2}$ ) ou LED (Dabi Atlante $150 \mathrm{~mW} / \mathrm{cm}^{2}$ ). O resultado do trabalho mostrou que os valores da força de contração obtidos no período de 120 segundos foram significantemente maiores que aos 60 segundos para todas as resinas, independente da fonte de luz. A resina A110 apresentou valores significantemente maiores que Z250 e P60 em todos os casos, e não houve diferenças entre Z250 e P60. Os valores obtidos com luz halógena foram significantemente maiores em comparação com LED nos períodos avaliados, com exceção da resina A110 aos 60 segundos. Os autores concluíram que resinas ativadas com LED apresentaram menores valores de força de contração em comparação com luz halógena.

SANTOS; SILVA E SOUZA JR.; MONDELLI ${ }^{66}$ realizaram uma revisão de literatura em 2002, na qual citam que a contração de polimerização é um dos fatores que mais contribui para o insucesso das resinas compostas e que ela é o resultado da movimentação e aproximação dos monômeros entre si durante a formação da cadeia polimérica. Afirmaram que quanto maior for o grau de conversão do monômero, maior seria a contração de polimerização, e que, nas resinas atuais, o grau de conversão fica em torno de 60 a 70\% e a contração de polimerização foi reduzida para 1,5 a 3\%. Relataram que a contração de polimerização é inerente às resinas compostas e irá persistir até que resinas sem contração ou portadoras de monômeros que sofram expansão durante a reação de polimerização estejam disponíveis. Concluíram que inúmeros fatores são responsáveis pelo estresse gerado na contração de polimerização, tais como módulo de elasticidade, composição da resina composta, fator de configuração da cavidade e intensidade de luz emitida pelo aparelho fotopolimerizador. Indicaram, como formas de minimizar esta contração, o uso de intensidades mais baixas de luz, com o intuito de prolongar a fase pré-gel, e o uso da técnica incremental, para reduzir o fator $\mathrm{C}$. 
Em 2003, FRANCO; LOPES ${ }^{38}$ publicaram uma revisão da literatura sobre todos os aspectos relacionados com os conceitos na polimerização dos sistemas restauradores resinosos. Descreveram a reação de polimerização tanto para resinas quimicamente ativadas como fotoativadas, tipos de fontes de luz existentes na atualidade com suas correspondentes densidades de potência e comprimentos de onda, importância das forças de contração na formação de fendas marginais, e a possibilidade de diminuí-las através de uma irradiação controlada, volume adequado de resina, conhecimento do efeito do fator $\mathrm{C}$, uso de bases intermediárias e conhecimento do conceito de densidade de energia.

CAVINA $^{16}$, em 2003 estudou a força de contração de polimerização de resinas compostas híbridas utilizando a metodologia descrita em CASTAÑEDAESPINOSA; MONDELLI ${ }^{14}$. Observou que a força de contração é dependente de cada formulação, sobretudo da relação entre matriz orgânica e partículas inorgânicas assim como da composição da matriz e das partículas. A curva forçatempo mostrou que as forças de contração foram geradas rapidamente nas resinas avaliadas (todas fotoativadas). Foi observado que ao momento de desligar a fonte de luz, a velocidade de formação de forças de contração aumentava por alguns segundos antes de voltar a retomar uma velocidade menor. As resinas Renew e Z-100 apresentaram os maiores valores de força de contração enquanto que Admira, Z-250, Synergy e Renamel apresentaram os menores valores. Chamou a atenção do autor o baixo valor obtido por Admira, em relação à percentagem de carga, sendo explicado esses baixos valores pela formulação da matriz da resina, à base de Ormocer.

CAVALCANTI; CASTAÑEDA-ESPINOSA; MONDELLI ${ }^{15}$ avaliaram as forças de contração de polimerização utilizando diferentes métodos de irradiação com a mesma densidade de energia. Utilizaram a mesma metodologia descrita nos trabalhos anteriores. Os diferentes métodos de ativação avaliados incluíram; 
1) $500 \mathrm{~mW} / \mathrm{cm}^{2}$ durante 30 segundos por duas vezes, deixando um período de 30 segundos entre cada irradiação, 2) $500 \mathrm{~mW} / \mathrm{cm}^{2}$ durante 60 segundos e, 3) $500 \mathrm{~mW} / \mathrm{cm}^{2}$ durante 20 segundos por três vezes, deixando um período de 20 segundos entre cada irradiação. Em todos os casos a densidade de potência foi de $30 \mathrm{~J} / \mathrm{cm}^{2}$. Os resultados mostraram que não existiu diferença estatisticamente significante entre os grupos 1 e 3, porém o grupo 2 apresentou valores de força de contração significantemente maiores que os outros grupos. Os autores concluíram que uma irradiação prolongada geraria maior força de contração de polimerização, quando comparada com repetidas irradiações de menor duração, mesmo que a densidade de energia seja a mesma, devendo-se evitar tempos de irradiação que excedam 30 segundos contínuos.

CAVINA et al. $^{17}$ estudaram a influência da densidade de energia sobre as forças de contração de uma resina composta. As forças foram registradas em uma máquina de ensaios especificamente montada para esse propósito (descrita em CASTAÑEDA-ESPINOSA; MONDELLI ${ }^{14}$ ). Todos os grupos foram polimerizados com uma fonte de luz LED de densidade de potência de $500 \mathrm{~mW} / \mathrm{cm}^{2}$, porém os tempos de irradiação foram; 1)10 segundos, 2) 20 segundos, 3) 30 segundos e, 4) 40 segundos. Os resultados mostraram diferenças significantes entre os grupos avaliados $(p<0,05)$. Ao teste de Tukey, comprovou-se que só o grupo irradiado por 10 segundos foi significantemente diferente que os outros grupos avaliados onde os valores foram maiores. Entre os outros grupos avaliados não existiu diferença estatisticamente significante. Concluiu-se que tempos menores que 20 segundos devem ser evitados pela possibilidade de não polimerizar o material adequadamente. Por outro lado, este estudo poderia sugerir que com fonte de luz LED a uma densidade de energia de $10 \mathrm{~J} / \mathrm{cm}^{2}$ uma aceitável polimerização estaria sendo lograda.

Ainda em 2003, ASENJO-MARTINEZ et al. ${ }^{3}$ avaliaram a força de contração de polimerização utilizando a técnica de rampa. Foi utilizada a mesma 
metodologia descrita em CASTAÑEDA-ESPINOSA; MONDELLI ${ }^{14}$. Os grupos avaliados foram: 1) $700 \mathrm{~mW} / \mathrm{cm}^{2}$ durante 40 segundos (densidade de energia 28 $\mathrm{J} / \mathrm{cm}^{2}$ ); 2) rampa $150-200 \mathrm{~mW} / \mathrm{cm}^{2}$ durante 15 segundos até $700 \mathrm{~mW} / \mathrm{cm}^{2}$ durante 25 segundos (densidade de energia de $20 \mathrm{~J} / \mathrm{cm}^{2}$ ); 3) $450 \mathrm{~mW} / \mathrm{cm}^{2}$ durante 20 segundo (densidade de energia de $9 \mathrm{~J} / \mathrm{cm}^{2}$ ) e; 4) $700 \mathrm{~mW} / \mathrm{cm}^{2}$ durante 20 segundos (densidade de energia de $14 \mathrm{~J} / \mathrm{cm}^{2}$ ). Os valores das médias obtidos foram $6,07 \mathrm{~N} ; 5,71 \mathrm{~N} ; 5,64 \mathrm{~N}$ e $5,80 \mathrm{~N}$ para os grupos $1,2,3,4$ respectivamente. $\mathrm{O}$ grupo 1 apresentou valores significantemente maiores que os outros grupos avaliados e os grupos 2, 3 e 4 não apresentaram diferenças significantes entre eles. Observou-se que a técnica em rampa com densidade de energia de $20 \mathrm{~J} / \mathrm{cm}^{2}$ apresentou força e contração de polimerização significantemente menor que o grupo 1, onde a densidade de energia foi de $28 \mathrm{~J} / \mathrm{cm}^{2}$, porém semelhante a os grupos 3 e 4 onde as densidades de potência foram inferiores (9 e $14 \mathrm{~J} / \mathrm{cm}^{2}$, respectivamente). Pode-se concluir que a técnica em rampa aparentemente favoreceu a liberação de força de contração quando comparado com os outros grupos avaliados, onde a densidade de energia foi menor ou maior.

Da mesma forma e com a mesma metodologia AZEVEDO et al. ${ }^{4}$ avaliaram a força de contração de polimerização utilizando a técnica de pulso tardio com a fonte de luz VIP. Os grupos avaliados incluíram; 1) $300 \mathrm{~mW} / \mathrm{cm}^{2}$ durante 20 segundos (densidade de energia $6 \mathrm{~J} / \mathrm{cm}^{2}$ ), 2) $600 \mathrm{~mW} / \mathrm{cm}^{2}$ durante 10 segundos (densidade de energia de $6 \mathrm{~J} / \mathrm{cm}^{2}$ ), 3) $600 \mathrm{~mW} / \mathrm{cm}^{2}$ durante 20 segundos (densidade de energia de $12 \mathrm{~J} / \mathrm{cm}^{2}$ ) e, 4) $100 \mathrm{~mW} / \mathrm{cm}^{2}$ durante 5 segundos, 40 segundos de espera e $600 \mathrm{~mW} / \mathrm{cm}^{2}$ durante 20 segundos (densidade de energia de $12,5 \mathrm{~J} / \mathrm{cm}^{2}$ ). Os resultados mostraram valores médios para $\mathrm{G} 1=5,52 \mathrm{~N}, \mathrm{G} 2=$ $5,86 \mathrm{~N}, \mathrm{G} 3=6,14 \mathrm{~N}$ e $\mathrm{G} 4=5,56 \mathrm{~N}$. Ao análise estatístico observou-se que G3 apresentou maiores valores que os outros grupos avaliados. O grupo polimerizado com menor densidade de potência (G1) e com a técnica de pulso tardio (G4) apresentaram valores significantemente menores que os grupos 2 e 3 , independentemente da densidade de energia. Pode-se notar ao comparar os grupos 1 e 2, onde a densidade de energia foi a mesma, que a alta densidade de 
potência induz a maiores valores de força de contração. Ao comparar os grupos 2 e 3 observou-se que, mantendo a mesma densidade de potência, o maior tempo de irradiação também promove maiores valores de contração de polimerização. Ao observar o grupo 3 com o grupo 4 verificou-se que mesmo com maior densidade de energia, mesma densidade de potência e tempo no segundo período deste grupo, a presença de uma irradiação inicial curta de baixa densidade de potência e um descanso antes da irradiação em alta densidade de potência favoreceu ao grupo onde a técnica do pulso tardio foi utilizado promovendo valores significantemente menores que o grupo 3.

Em 2004, COELHO SANTOS et al. ${ }^{21}$ avaliaram o efeito do método de fotoativação sobre a contração volumétrica de resinas compostas. Com essa finalidade foi determinada a contração de polimerização de três resinas compostas: Z-100, P-60 e Suprafil. Os métodos de fotoativação avaliados incluíram: 1) irradiação contínua a intensidade convencional; 2) irradiação contínua a alta intensidade; 3) irradiação progressiva e 4) irradiação com o método de pulso retardado. Foram realizados 5 discos para cada condição de teste. Os corpos de prova foram pesados com uma balança analítica hidrostática eletrônica tanto em ar quanto em água para determinar os valores de gravidade específica. A contração volumétrica foi calculada matematicamente. Os resultados mostraram diferenças estatisticamente significantes entre os materiais avaliados, porém não existiu diferença estatisticamente significante entre os métodos empregados, exceto para Z-100 onde o método 2 resultou em maior contração volumétrica que os métodos 1 e 4 . Os autores concluíram que o método de fotoativação não teve um efeito significante sobre a contração volumétrica das resinas compostas.

Ainda em 2004, SAKAGUCHI; WILTBANK; MURCHISON ${ }^{70}$ mencionaram que a força gerada durante a polimerização das resinas compostas representa as forças que potencialmente poderiam afetar a integridade do adesivo, do dente e a união entre eles. Assim, estudaram a relação entre a densidade de energia e a 
força de contração. A metodologia utilizada foi o registro das forças de contração de polimerização através de uma máquina de ensaios universal onde foram confeccionados corpos de prova cilíndricos de resina com $5 \mathrm{~mm}$ de diâmetro e $1,1 \mathrm{~mm}$ de altura. O corpo de prova foi introduzido entre duas bases de vidro. A luz foi transmitida através da base de vidro inferior. A força de contração foi registrada durante 600 segundos e a fotoativação durante 60 segundos. Foram avaliados 7 grupos; Os primeiros 6 grupos foram incrementando a densidade de potência de 100 até $600 \mathrm{~mW} / \mathrm{m}^{2}$, o sétimo grupo foi irradiado utilizando a técnica de pulso retardado. Os resultados mostraram que a força de contração de polimerização aumentou rapidamente seguindo a fotoativação, mostrando uma descontinuidade no trajeto da curva logo após a luz ter sido desligada. A força de contração mostrou-se estabilizada aproximadamente aos 500 segundos. A força resultante do método de pulso retardado foi significantemente diferente que nos outros grupos avaliados. A força resultante da irradiação com $600 \mathrm{~mW} / \mathrm{cm}^{2}$ foi significantemente diferente que os outros grupos, e $500 \mathrm{~mW} / \mathrm{cm}^{2}$ foi diferente que 100 e $200 \mathrm{~mW} / \mathrm{cm}^{2}$. A velocidade com que as força de contração foram geradas esteve linearmente correlacionada com a densidade de potência quando esta foi irradiada em um só episodio. Esta correlação não foi muito evidente quando os valores máximos foram relacionados com o tempo ou o tipo de irradiação, mostrando que a magnitude da força de contração foi praticamente idêntico nos grupos irradiados com intensidade entre 200 e $400 \mathrm{~mW} / \mathrm{cm}^{2}$. O método de pulso retardado mostrou uma velocidade menor na formação de forças de contração de polimerização. 
3. PROPOSIÇÃO 


\section{PROPOSIÇÃO}

\subsection{Objetivo Geral:}

- Avaliar as forças de contração de polimerização de resinas compostas, em função do tipo de resina composta, modo de ativação, fonte de luz e utilização de material intermediário.

\subsubsection{Objetivos Específicos:}

- Avaliar comparativamente os valores das forças de contração de polimerização de uma resina composta quimicamente ativada em relação às resinas compostas fotoativadas de micropartículas, partículas microhíbridas e de alta viscosidade.

- Avaliar comparativamente os valores das forças de contração de polimerização obtidos de uma resina composta de partículas microhíbridas quando polimerizada com fonte de luz halógena, fonte de luz emitida por diodos (LED) de baixa e alta densidade de potência.

- Avaliar comparativamente os valores das forças de contração de polimerização obtidos de uma resina composta de partículas microhíbridas, 
uma resina fluida e um cimento de ionômero de vidro modificado com resina.

- Avaliar comparativamente a transmissão das forças de contração de polimerização de uma resina composta microhíbrida através da utilização de materiais intermediários, ionômero de vidro modificado por resina e resina de baixa viscosidade, com diferentes espessuras.

\subsection{Hipótese:}

- Ho: Nem o tipo de resina composta, nem o tipo de fonte de luz, nem o material intermediário avaliado apresentarão alguma influência nas forças de contração da resina composta.

- $\mathrm{H}_{1}$ : Tanto o tipo de resina composta como o tipo de fonte de luz e material intermediário apresentarão influência nas forças de contração da resina composta. 
4. MATERIAIS E MÉTODO 


\section{MATERIAIS E MÉTODO}

\subsection{Desenho do teste}

As forças de contração de polimerização foram registradas em uma máquina de ensaios Emic (DL 500 BF-N05775-NS168, Paraná, Brasil) (Figura 4.1). Para realizar o teste foram confeccionadas duas bases de aço. O extremo, para sua fixação na máquina de ensaios, foi de forma cilíndrica e o extremo oposto, livre, de forma retangular. As bases foram posicionadas uma acima da outra, de forma paralela, opostas, e com seu longo eixo na vertical. Uma base foi fixada, através de um pino, a uma célula de carga de 10kgf fixa ao braço móvel superior da máquina de ensaios e a outra ao braço fixo inferior através de um dispositivo Bencor Multiteste modificado para esse propósito.

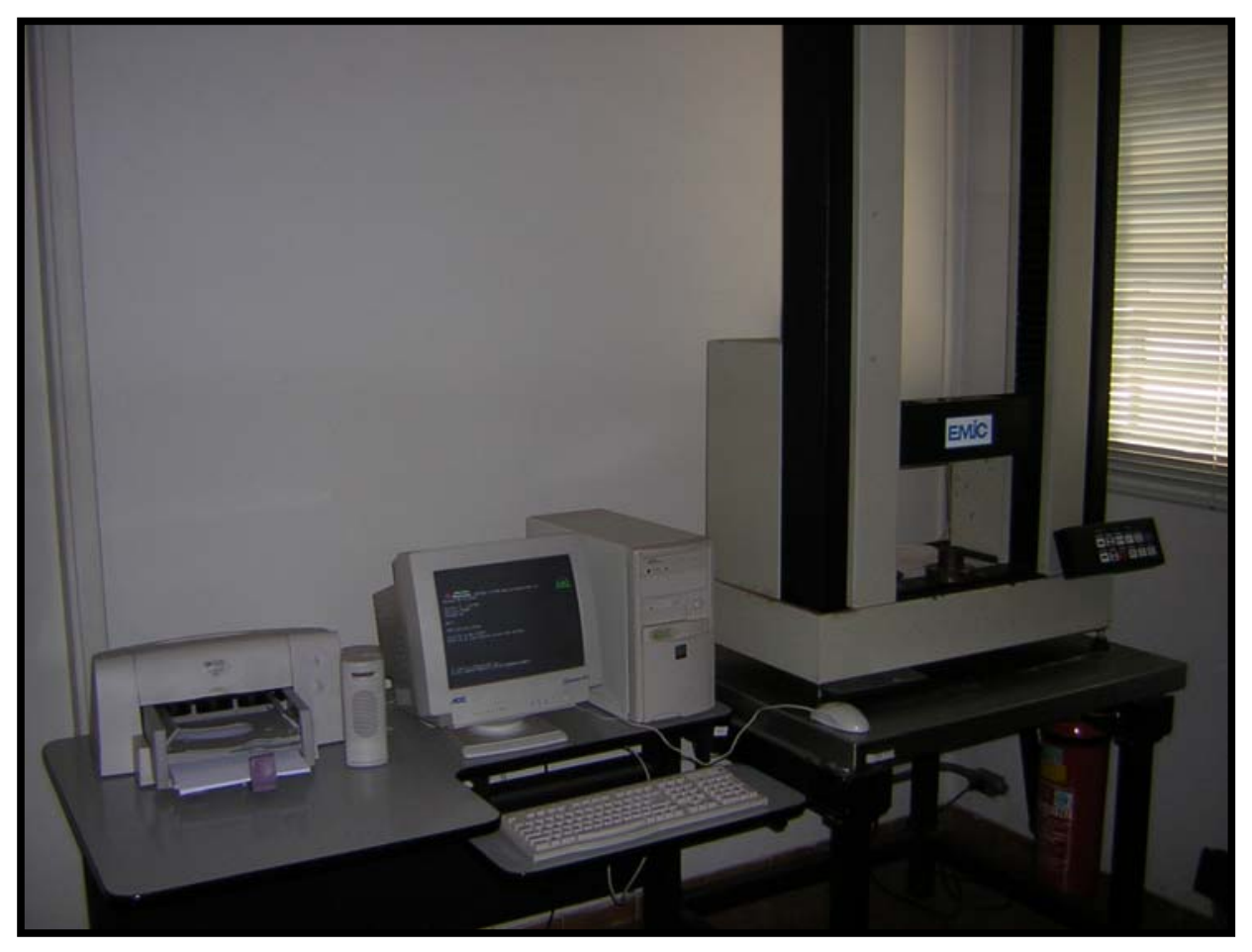

Figura 4.1 Mesa de trabalho com máquina de ensaios Emic conectada a computador. 
Uma vez montadas as bases de aço na máquina de ensaios, o braço móvel foi movimentado até apresentar contato entre elas. Nessa posição a máquina foi zerada, e o braço móvel foi novamente movimentado até conseguir uma separação exata de $1 \mathrm{~mm}$ entre as duas bases de aço, conformando o "espaço padrão", onde a resina composta foi aplicada para sua avaliação (Figura 4.2).

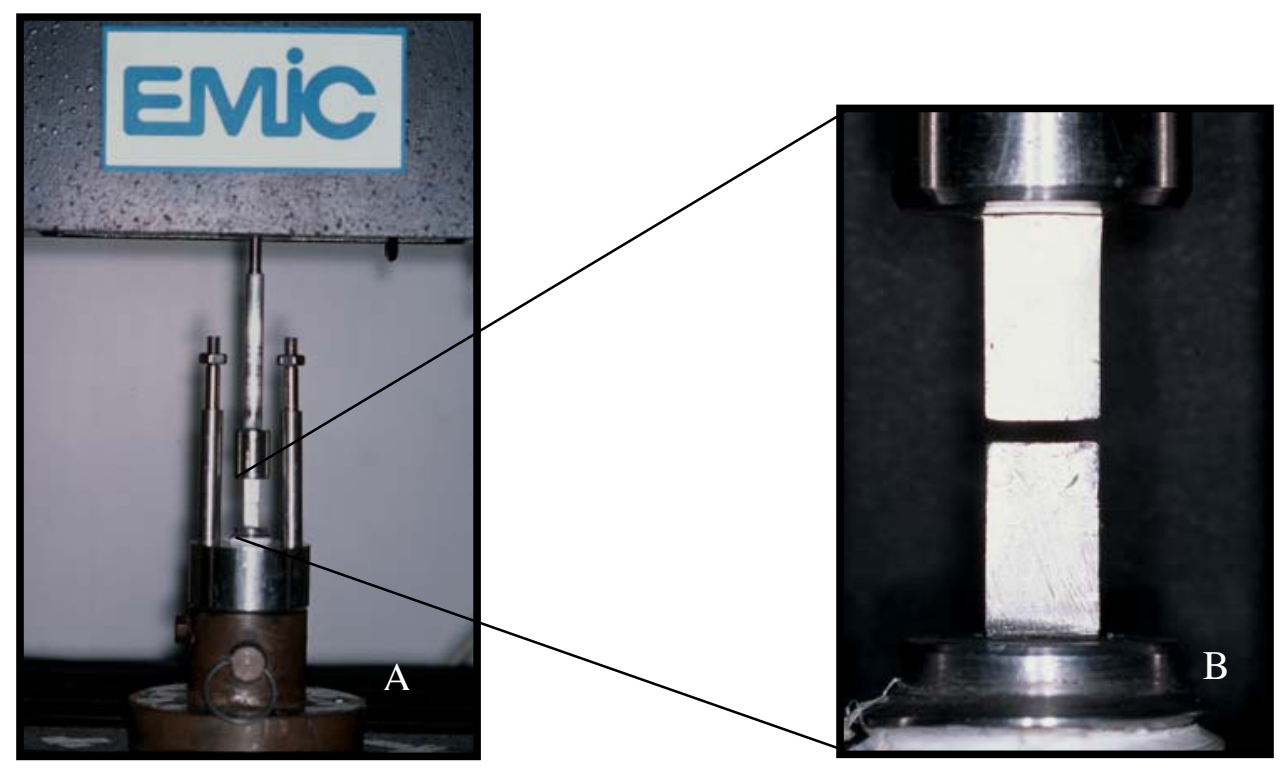

Figura 4.2 A) Máquina de ensaios Emic com as bases de aço em posição, B) Vista aproximada do extremo cilíndrico das bases e separação de $1 \mathrm{~mm}$ entre elas para aplicação da resina composta.

Este "espaço padrão", com fator de configuração (fator C) pré-determinado, foi necessário para padronizar a relação entre contração restrita e contração livre do corpo-de-prova de resina composta. O fator de configuração foi calculado a partir da fórmula:

Fator de configuração: $\mathrm{C}=\mathrm{SA} / \mathrm{SL}^{34}$. 
Onde SA= Superfície aderida e SL superfície livre. A superfície aderida do corpo-de-prova retangular foi calculada a partir da somatória das áreas em contato com as bases de aço, expressado como (2AC). A superfície livre foi calculada pela somatória das superfícies expostas, sendo estas (2AB + 2BC) (Figura 4.3).

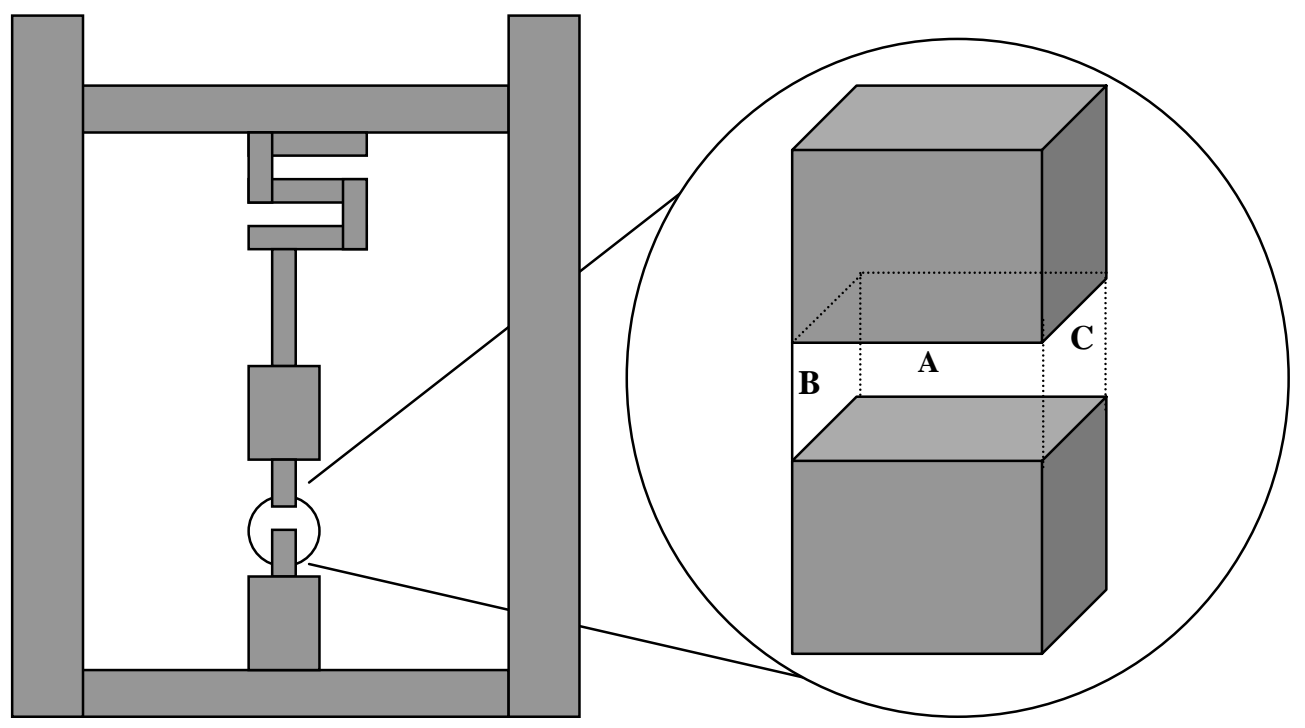

Figura 4.3 Desenho da montagem e dimensões do espaço entre as bases $(A=6$ $\mathrm{mm}$ de largura, $\mathrm{B}=1 \mathrm{~mm}$ de altura, $\mathrm{C}=2 \mathrm{~mm}$ de profundidade).

O espaço entre as duas bases foi de $6 \mathrm{~mm}$ de largura, $1 \mathrm{~mm}$ de altura e $2 \mathrm{~mm}$ de profundidade, correspondendo às dimensões do corpo-de-prova. O fator de configuração pode ser calculado pela relação (Figura 4.3):

$$
\mathrm{C}=\mathrm{SA} / \mathrm{SL} \rightarrow 2 \mathrm{AC} / 2 \mathrm{AB}+2 \mathrm{BC}
$$

Considerando as dimensões das bases e conseqüentemente do espaço padrão, o fator de configuração do corpo-de-prova foi:

$$
C=2(6 \times 2) / 2(6 \times 1)+2(2 \times 1)=1,5
$$


Estas dimensões correspondem a um fator de configuração de 1,5, valor compatível com cavidades de classe II, III e $\mathrm{V}^{34}$. A resina composta foi inserida dentro do "espaço padrão" com uma espátula metálica, em incremento único, e moldada de acordo às superfícies externas das bases de aço (Figura 4.4), constituindo o corpo-de-prova. Não foi necessário o uso de adesivo nas superfícies das bases de aço, uma vez que estas oferecerem suficiente retenção para as forças desenvolvidas pela resina composta durante a contração de polimerização.
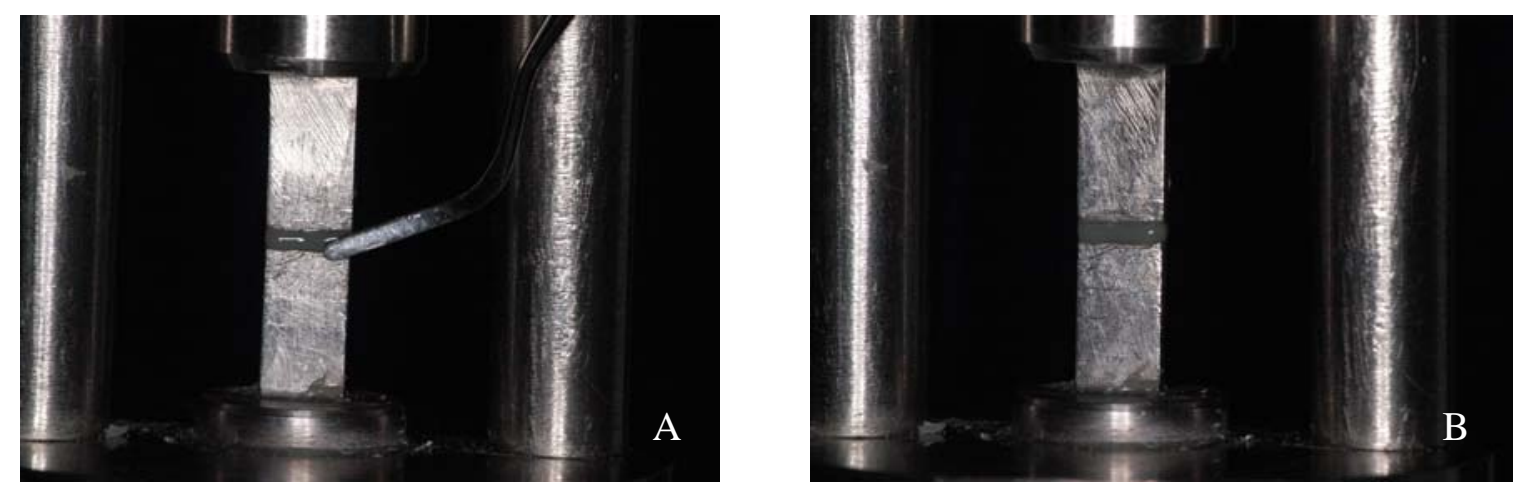

Figura 4.4 A: Corpo-de-prova de resina composta moldado na forma das bases de aço. B: Corpo-de-prova de resina composta pronto para fotoativação e avaliação.

Após a inserção e adaptação da resina composta entre as bases, o teste foi iniciado simultaneamente com a fotoativação e por um período pré-determinado para cada grupo. Este procedimento foi realizado com a ponta do aparelho fotoativador o mais próximo possível do corpo-de-prova, na sua face mais extensa $(6 \mathrm{~mm})$, de modo a ter uma espessura uniforme de material irradiado de $2 \mathrm{~mm}$ (Figura 4.5). Para cada grupo foram realizados 10 ensaios. 


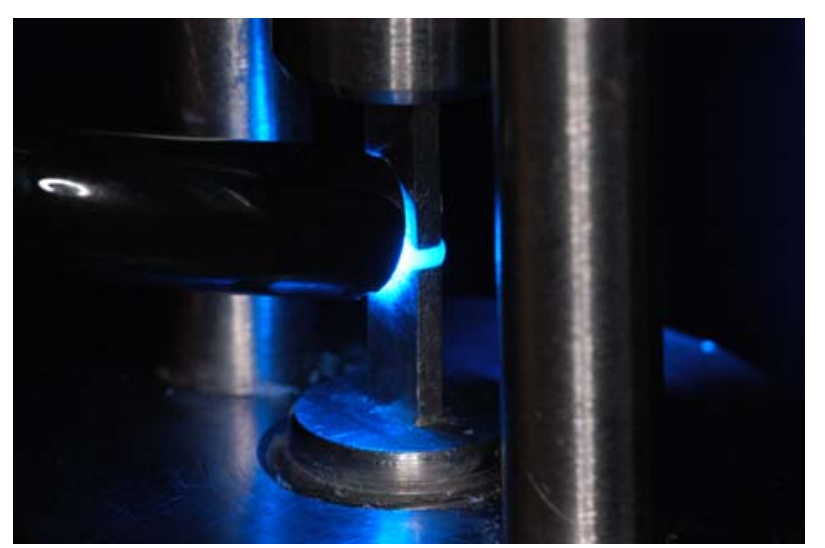

Figura 4.5 Corpo-de-prova de resina composta sendo fotoativado.

Para o registro dos valores de forças de contração de polimerização foi desenvolvido um método para o computador (Software) utilizado pela máquina de ensaios. O método utilizou basicamente um teste de tração, porém manteve a máquina de ensaios imóvel durante os ensaios, não permitindo o movimento do braço móvel da máquina. Uma diferença com os testes de tração convencionais foi que neste trabalho a força não foi gerada desde a máquina de ensaios, sendo que esta força foi gerada desde o material avaliado aderido às superfícies das bases de aço. As forças de contração de polimerização foram transmitidas através da base superior de aço até chegar à célula de carga de $10 \mathrm{Kgf}$ originando mínima deformação, que foi traduzida novamente como força no programa da máquina de ensaios. Durante o ensaio cada corpo-de-prova descreveu uma curva relacionando força, expressada em Newton (N), com o tempo transcorrido, expressado em segundos (s). As forças máximas de contração foram registradas e submetidas à análise de variância e teste de Tukey para sua comparação. 


\subsection{Testes}

Foram realizados três testes diferentes. No primeiro, foram avaliados a influência do tipo de resina composta e seu modo de ativação sobre as forças de contração de polimerização. No segundo, foi avaliada a influência da densidade de potência e natureza da fonte de luz sobre as forças de contração de polimerização de uma resina composta. No terceiro foram avaliadas as forças de contração de polimerização de materiais intermediários e a transmissão das forças de contração de polimerização de uma resina composta através desses materiais intermediários.

\subsubsection{Avaliação da influência do tipo de resina composta e modo de ativação sobre as forças de contração de polimerização.}

Foram avaliadas quatro resinas compostas, sendo uma ativada quimicamente e três fotoativadas (Tabela 4.1 e Figura 4.6). Foi utilizada a resina composta quimicamente ativada Concise (3M-ESPE, St. Paul, Minnesotta, USA, batch number \# 03031) e as resinas compostas fotoativadas de micropartículas Filtek A-110 (3M-ESPE, St. Paul, Minnesotta, USA, batch number OAM), de partículas microhíbridas Filtek Z-250 (3M-ESPE, St. Paul, Minnesotta, USA, batch number 1LG) e de alta viscosidade Filtek P-60 (3M-ESPE, St. Paul, Minnesotta, USA, batch number $1 \mathrm{KL}$ ). 
Tabela 4.1. Grupos experimentais avaliados com seus respectivos tipos de resinas compostas e marcas comerciais.

\begin{tabular}{|c|c|c|c|c|}
\hline $\begin{array}{c}\text { Grupos } \\
\text { experimentais }\end{array}$ & Grupo 1 & Grupo 2 & Grupo 3 & Grupo 4 \\
\hline $\begin{array}{c}\text { Tipo de resina } \\
\text { composta }\end{array}$ & $\begin{array}{c}\text { Resina } \\
\text { composta } \\
\text { quimicamente } \\
\text { ativada }\end{array}$ & $\begin{array}{c}\text { Resina } \\
\text { composta } \\
\text { fotoativada de } \\
\text { micropartículas }\end{array}$ & $\begin{array}{c}\text { Resina } \\
\text { composta } \\
\text { fotoativada de } \\
\text { partículas } \\
\text { microhíbridas }\end{array}$ & $\begin{array}{c}\text { Resina } \\
\text { composta } \\
\text { fotoativada de } \\
\text { alta } \\
\text { viscosidade }\end{array}$ \\
\hline $\begin{array}{c}\text { Marca } \\
\text { Comercial }\end{array}$ & Concise & Filtek A-110 & Filtek Z-250 & Filtek P-60 \\
\hline
\end{tabular}

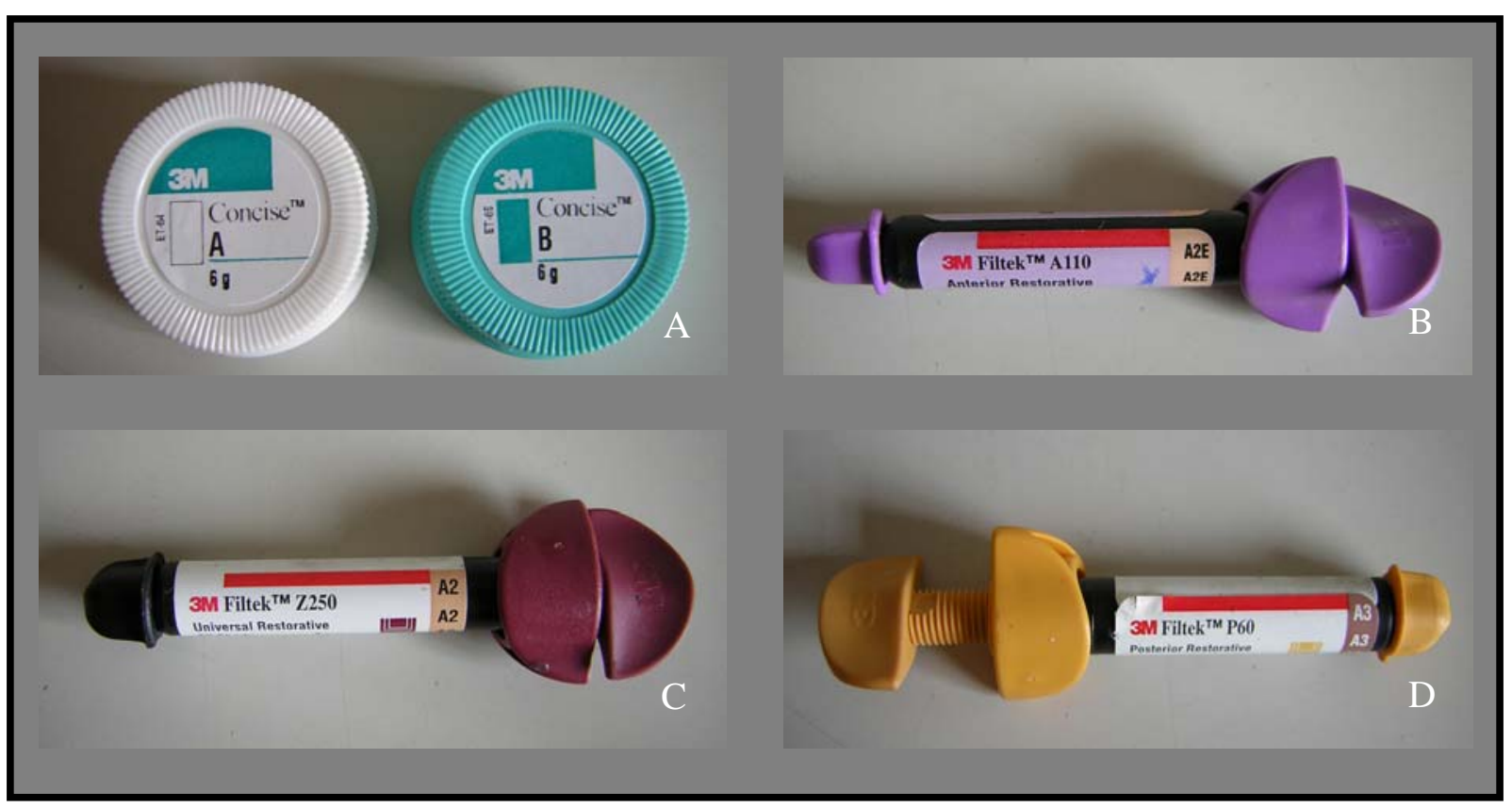

Figura 4.6 A) Concise. B) Filtek A-110. C) Filtek Z-250. D) Filtek P-60. 
A resina Concise foi misturada seguindo as instruções do fabricante, durante um período de 30 segundos, para então ser introduzida no espaço padrão e moldada na forma das bases de aço dentro de um período de 90 segundos. Transcorridos estes períodos, o ensaio foi iniciado e as forças geradas pelo material começaram a ser registradas por um período de 600 segundos.

As resinas compostas fotoativadas foram introduzidas entre as bases de aço e moldadas na forma destas durante um período de 90 segundos. Após este procedimento, deu-se início ao ensaio simultaneamente com a fotoativação, porém o ensaio estendeu-se por 600 segundos, enquanto a fotoativação foi realizada somente os primeiros 60 segundos. Este procedimento foi realizado com um aparelho com fonte de luz halógena marca Spectrum (Dentsply-Caulk, Milford, Canada) e densidade de potência de $500 \mathrm{~mW} / \mathrm{cm}^{2}$. Os dados foram submetidos a análise de variância a um criterio e teste de Tukey com $p<0,05$.

\subsubsection{Avaliação da influência da fonte de luz e densidade de potência sobre as forças de contração de polimerização de uma resina composta.}

Foram avaliadas as forças de contração de polimerização da resina composta Filtek Z-250 quando polimerizada com fonte de luz halógena ou LED. Em total, foram avaliados quatro grupos, utilizando três aparelhos fotoativadores, sendo um aparelho com fonte de luz halógena e dois com luz emitida por diodos (LED) (Tabela 4.2). O tempo de fotoativação para todos os grupos foi de 60 segundos.

No primeiro grupo foi utilizado um aparelho com fonte de luz halógena, modelo Spectrum (Dentsply-Caulk, Milford, Canada), com densidade de potência 
de $500 \mathrm{~mW} / \mathrm{cm}^{2}$ (Tabela 4.2 e Figura 4.7). No segundo grupo foi utilizado o aparelho com fonte de luz LED modelo Ultraled (Dabi-Atlante, São Paulo, Brasil) com densidade de potência de $140 \mathrm{~mW} / \mathrm{cm}^{2}$ (Tabela 4.2 e Figura 4.8 A e B). No terceiro e quarto grupo foi utilizado o modelo Ultrablue IS (DMC, Brasil) com dois programas diferentes (Figura 4.9). Nestes grupos a densidade de potência foi de $200 \mathrm{~mW} / \mathrm{cm}^{2}$ durante os cinco segundos iniciais para logo aumentar rapidamente até $300 \mathrm{~mW} / \mathrm{cm}^{2}$ (grupo 3) ou $600 \mathrm{~mW} / \mathrm{cm}^{2}$ (grupo 4) (Tabela 4.2). O ensaio foi iniciado simultaneamente com a fotoativação e por um período de 120 segundos. Os dados foram submetidos a análise de variancia a um criterio e teste de Tukey com $\mathrm{p}<0,05$.

Tabela 4.2. Grupos experimentais.

\begin{tabular}{c|c|c|c|c}
\hline Grupos & Grupo1 & Grupo 2 & Grupo 3 & Grupo 4 \\
\hline $\begin{array}{c}\text { Resina } \\
\text { composta }\end{array}$ & Filtek Z-250 & Filtek Z-250 & Filtek Z-250 & Filtek Z-250 \\
\hline $\begin{array}{c}\text { Aparelho } \\
\text { fotoativador }\end{array}$ & Halógeno & LED & LED & LED \\
& $500 \mathrm{~mW} / \mathrm{cm}^{2}$ & $140 \mathrm{~mW} / \mathrm{cm}^{2}$ & $300 \mathrm{~mW} / \mathrm{cm}^{2}$ & $600 \mathrm{~mW} / \mathrm{cm}^{2}$ \\
\hline
\end{tabular}

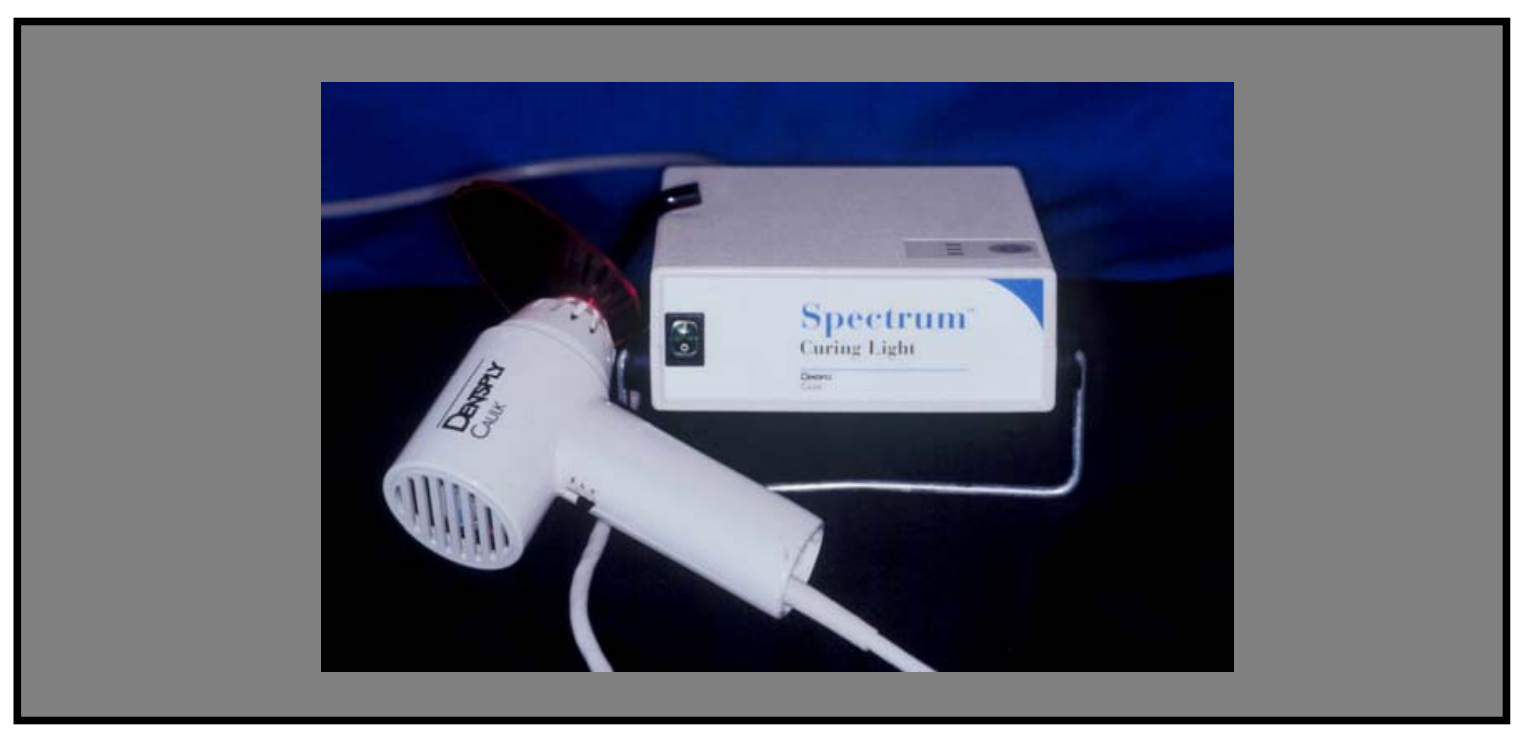

Figura 4.7 Aparelho fotoativador modelo Spectrum. 

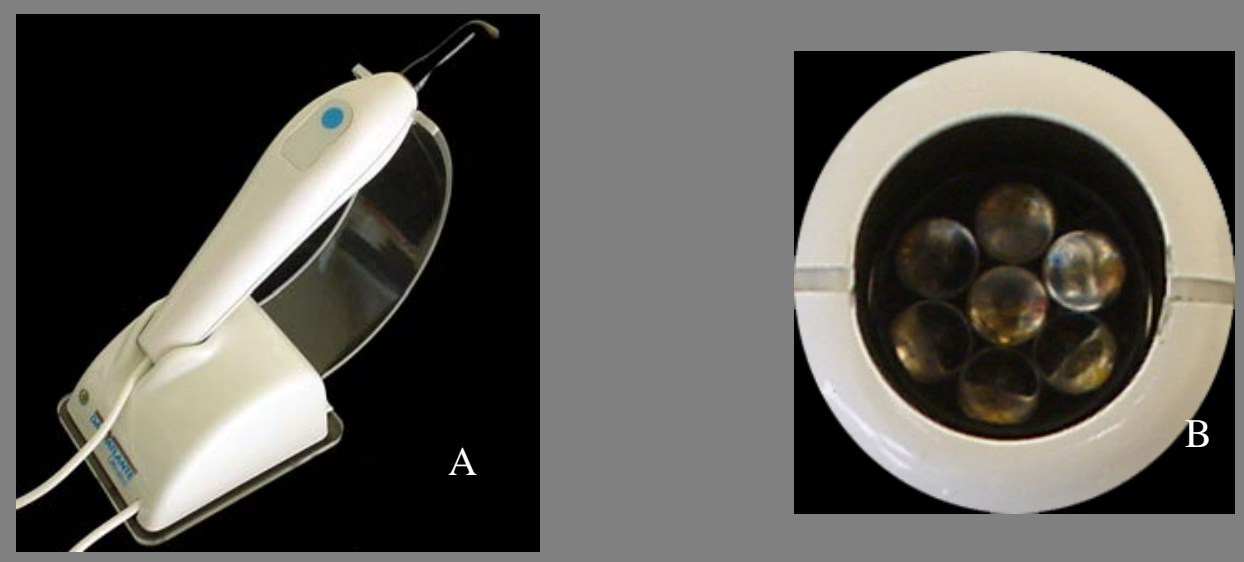

Figura 4.8 A) Aparelho fotoativador modelo Ultraled. B) Fonte de luz, 7 LED.

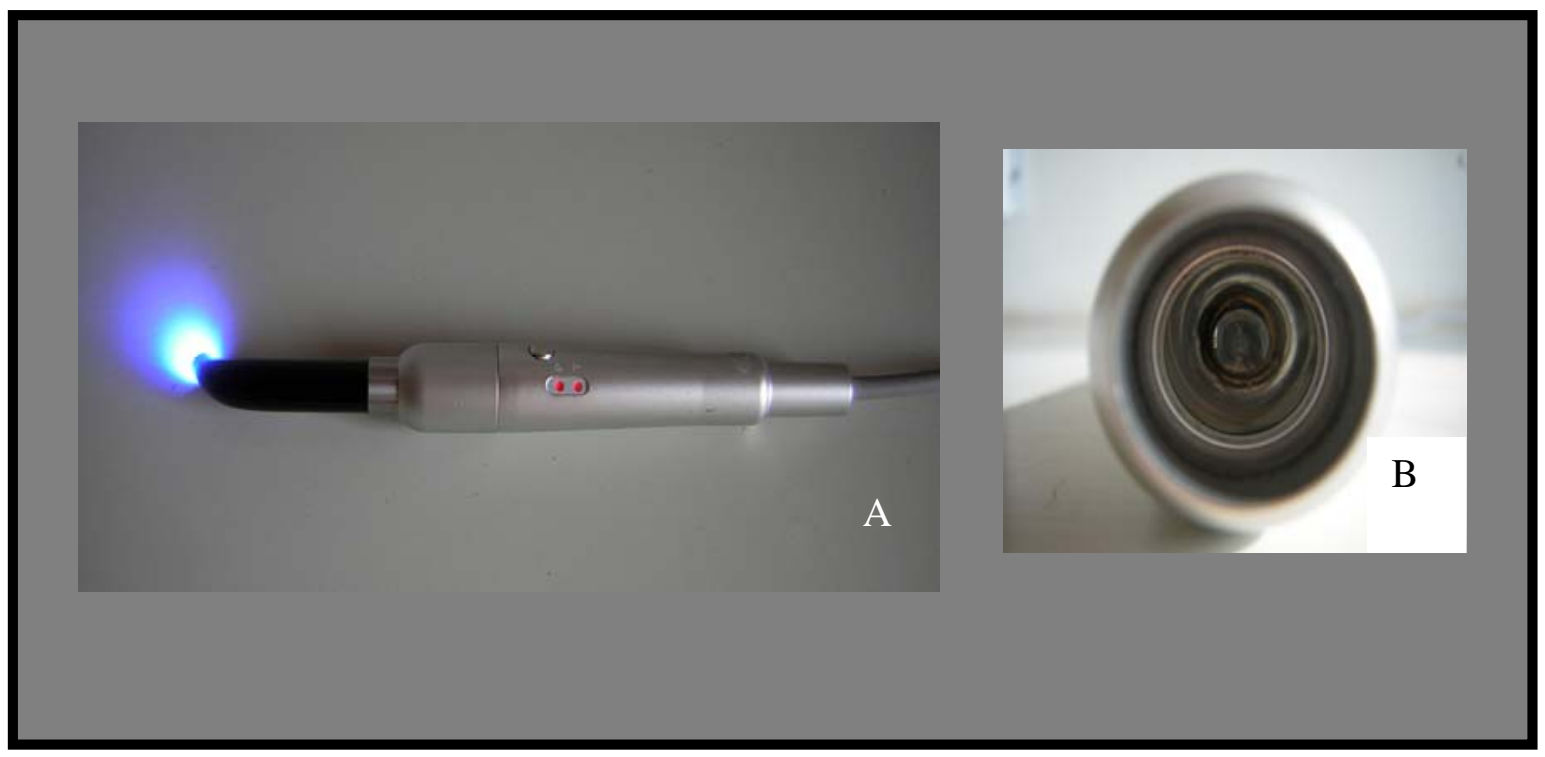

Figura 4.9 A) Aparelho fotoativador modelo Ultrablue IS. B) Fonte de luz, 1 LED. 
4.2.3 Avaliação das forças de contração de polimerização em função da utilização de materiais intermediários.

Foram avaliadas as forças de contração de polimerização de dois materiais intermediários, cimento de ionômero de vidro modificado por resina Vitrebond (3MESPE, St. Paul, Minnesotta, USA, batch number $2 \mathrm{CN}$ ) e resina de baixa viscosidade Filtek Flow (3M-ESPE, St. Paul, Minnesotta, USA, batch number 1BF) (Figura4.10). Também foi avaliada a influência desses materiais intermediários em modificar as forças de contração de polimerização transmitidas pela resina composta Filtek Z-250 (3M-ESPE, St. Paul, Minnesotta, USA, batch number 1LG), através deles, em direção à máquina de ensaios. Como grupo controle foram utilizados os valores obtidos para Z-250 utilizados nos testes A e B (Tabelas 4.3 e 4.4).

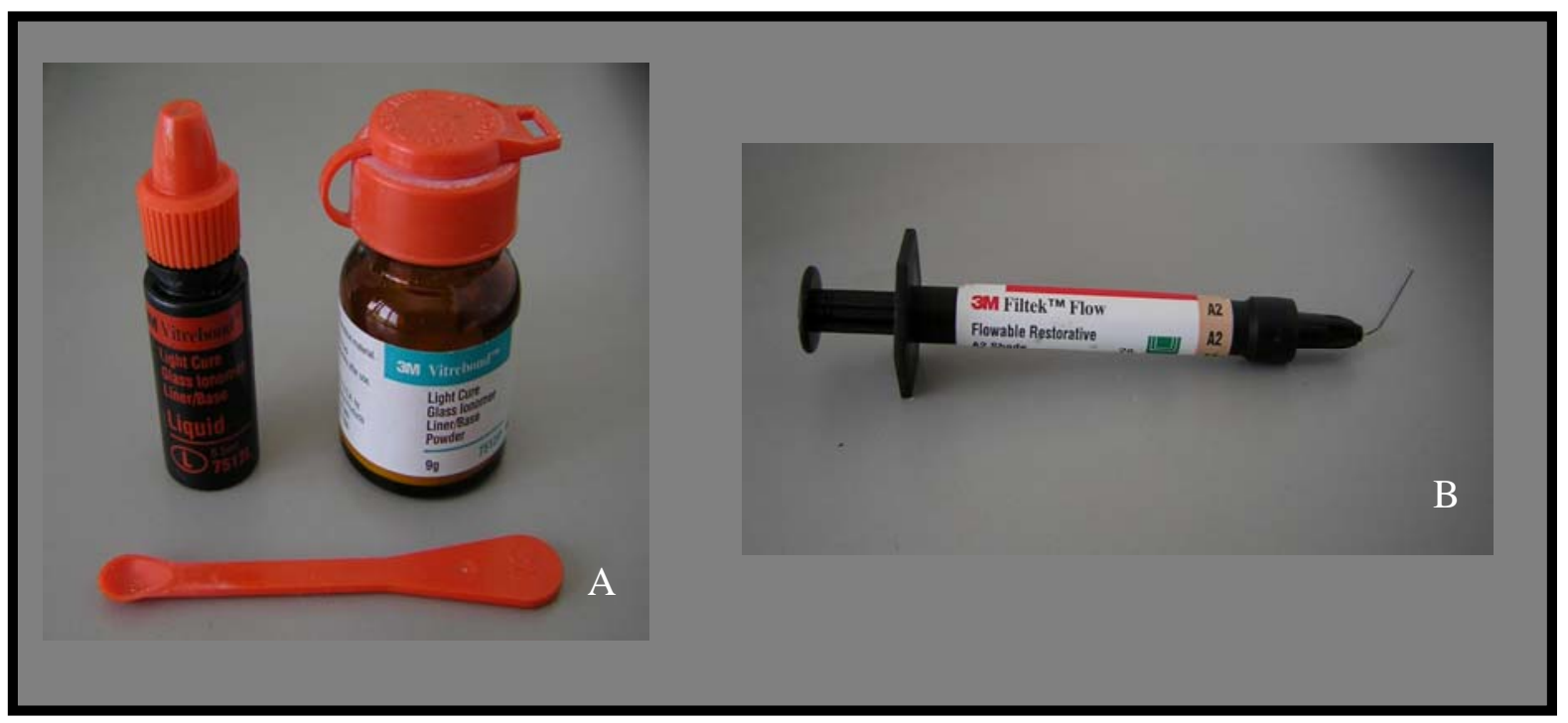

Figura 4.10 A) Cimento de ionômero de vidro modificado por resina Vitrebond. B) Resina de baixa viscosidade Filtek Flow. 
4.2.3.1 Teste A: Avaliação das forças de contração de polimerização do cimento de ionômero de vidro Vitrebond e resina de baixa viscosidade Filtek Flow.

Foram avaliadas as forças de contração de polimerização do cimento de ionômero de vidro Vitrebond e resina de baixa viscosidade Filtek Flow (Tabela 4.3 e Figura 4.10). Os materiais foram introduzidos entre as duas bases de aço no espaço padrão e moldados de acordo à forma destas. Para a fotoativação foi utilizada uma fonte de luz halógena marca Spectrum (Dentsply-Caulk, Milford, Canada) com densidade de potência de $500 \mathrm{~mW} / \mathrm{cm}^{2}$ (Figura 4.7). A resina Filtek Flow e o cimento Vitrebond foram fotoativados por 20 e 30 segundos respetivamente, de acordo à indicação do fabricante. As forcas foram registradas por 120 segundos. Os dados foram submetidos a análise de variância a um critério e teste de Tukey com $p<0,05$.

Tabela 4.3: Grupos avaliados e materiais utilizados.

\begin{tabular}{|c|c|c|c|}
\hline Grupos avaliados & Grupo 1 (Controle) & Grupo 2 & Grupo 3 \\
\hline Materiais utilizados & $\begin{array}{l}\text { Resina composta } \\
\text { de partículas } \\
\text { microhíbridas }\end{array}$ & $\begin{array}{l}\text { cimento de } \\
\text { ionômero de vidro } \\
\text { modificado por } \\
\text { resina }\end{array}$ & Resina fluida \\
\hline Marcas Comerciais & Filtek Z-250 & Vitrebond & Filtek Flow \\
\hline
\end{tabular}


4.2.3.2. Teste B: Avaliação da transmissão das forças de contração de polimerização da resina composta Filtek Z-250 através de camadas com diferentes espessuras do cimento de ionômero de vidro modificado por resina Vitrebond e resina de baixa viscosidade Filtek Flow.

Foram avaliados cinco grupos, sendo o Grupo 1 (resina composta microhíbrida Filtek Z-250, sem material intermediário) o grupo controle. Para os grupos experimentais foi avaliara a transmissão das forças de contração de polimerização da resina composta microhíbrida Filtek Z-250 com 1mm de altura através de uma camada de 0,5mm de espessura de Filtek Flow (grupo 2), uma camada de 1,0mm de espessura de Filtek Flow (grupo 3), uma camada de 0,5mm de espessura de Vitrebond (grupo 4) e uma camada de 1,0mm de espessura de Vitrebond (grupo 5) (Tabela 4.4).

Tabela 4.4. Materiais e combinações utilizadas no grupo controle e nos grupos experimentais para a avaliação da transmissão de forças de contração de polimerização através de materiais intermediários.

\begin{tabular}{c|c|c|c|c}
\hline grupo 1 & grupo 2 & grupo 3 & grupo 4 & grupo 5 \\
\hline & $0,5 \mathrm{~mm}$ & $1 \mathrm{~mm}$ & $0,5 \mathrm{~mm}$ & $1 \mathrm{~mm}$ \\
& Filtek Flow & Filtek Flow & Vitrebond & Vitrebond \\
\hline Filtek Z-250 & Filtek Z-250 & Filtek Z-250 & Filtek Z-250 & Filtek Z-250 \\
\hline
\end{tabular}

O procedimento para os grupos experimentais foi realizado da seguinte forma: a base inferior de aço foi isolada com fita teflón. A base superior foi movimentada afastando-se da inferior até criar um espaço de 0.5 ou $1.0 \mathrm{~mm}$ entre elas, dependendo da espessura do material intermediário desejada. Esse espaço 
foi preênchido, com Filtek Flow ou Vitrebond, e polimerizado por 20 ou 30 segundos, respetivamente. Depois da fotoativação, as bases de aço foram afastadas novamente para retirar a fita de teflón da base inferior. O material intermediário permaneceu aderido à base superior de aço (Figura 4.11). Esta base por sua vez foi movimentada até estabelecer uma distância de um milimetro entre a superfície inferior do material intermediário e a base inferior de aço, criando o "espaço padrão" para ser preênchido com resina composta (Figura 4.11). Uma vez inserida a resina composta e moldeada entre o material intermediário e a base inferior de aço no "espaço padrão", a fotoativação e o ensaio foram iniciados simultaneamente, porém por periodos diferentes (60 segundos e 120 segundos respetivamente), procedendo-se a registrar as forças de contração de polimerização. Os dados foram submetidos a análise de variância a um critério e teste de Tukey com $\mathrm{p}<0,05$.

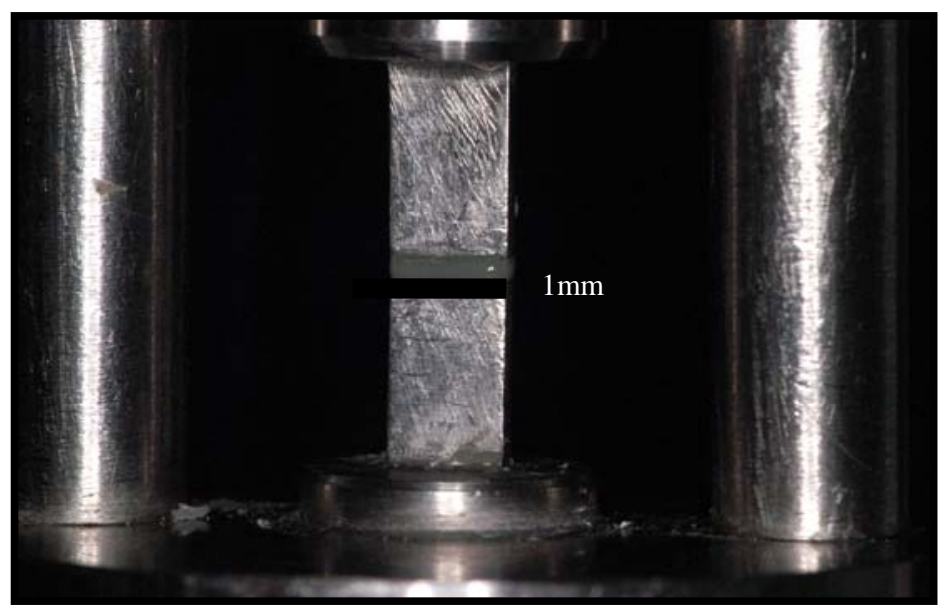

Figura 4.11 Material intermediário com espessura de $1 \mathrm{~mm}$. A base superior é movimentada até existir $1 \mathrm{~mm}$ de separação com a base de aço inferior, criando o "espaço padrão" para inserção da resina composta a ser avaliada. 
5. RESULTADOS 


\section{RESULTADOS}

\subsection{Avaliação da influência do tipo de resina composta e modo de ativação sobre as forças de contração de polimerização.}

As resinas compostas química e fisicamente ativadas descreveram curvas força-tempo com caraterísticas diferentes. A resina composta quimicamente ativada Concise começou a gerar forças de contração de polimerização após 60 segundos de iniciado o ensaio (180 segundos depois de iniciada a mistura do material). Os valores aumentaram gradualmente até aproximadamente 360 segundos, quando foi notado uma ligeira diminuição na velocidade com que as forças de contração de polimerização eram geradas, registrado como uma leve inclinação da curva para a direita. O material quimicamente ativado continuou gerando forças durante todo o período avaliado, sendo o valor obtido após 600 segundos utilizado para comparações com outros materiais. Esse valor aos 600 segundos coincidiu com o valor máximo registrado para todos os corpos de prova dentro do período avaliado (Figura 5.1).

As curvas obtidas pelas resinas fotoativadas apresentaram um padrão semelhante entre elas e diferente em relação à resina quimicamente ativada. Com o início do ensaio, em sincronia com o início da fotoativação, foi observado que as resinas compostas fotoativadas começaram rapidamente a gerar forças de contração de polimerização, com uma ligeira diminuição da velocidade (N/s) destas forças após um período de 30 segundos, ainda durante a fotoativação. No momento que a fotoativação foi terminada (60 segundos), as três resinas compostas avaliadas experimentaram, durante outros 30 segundos, um novo aumento na velocidade com que as forças foram geradas. Depois deste período, a velocidade voltou a diminuir, mantendo-se um pequeno aumento constante nos valores de forças até o final do ensaio, no período de 600 segundos, quando os valores máximos, foram registrados para análise (Figura 5.1). 


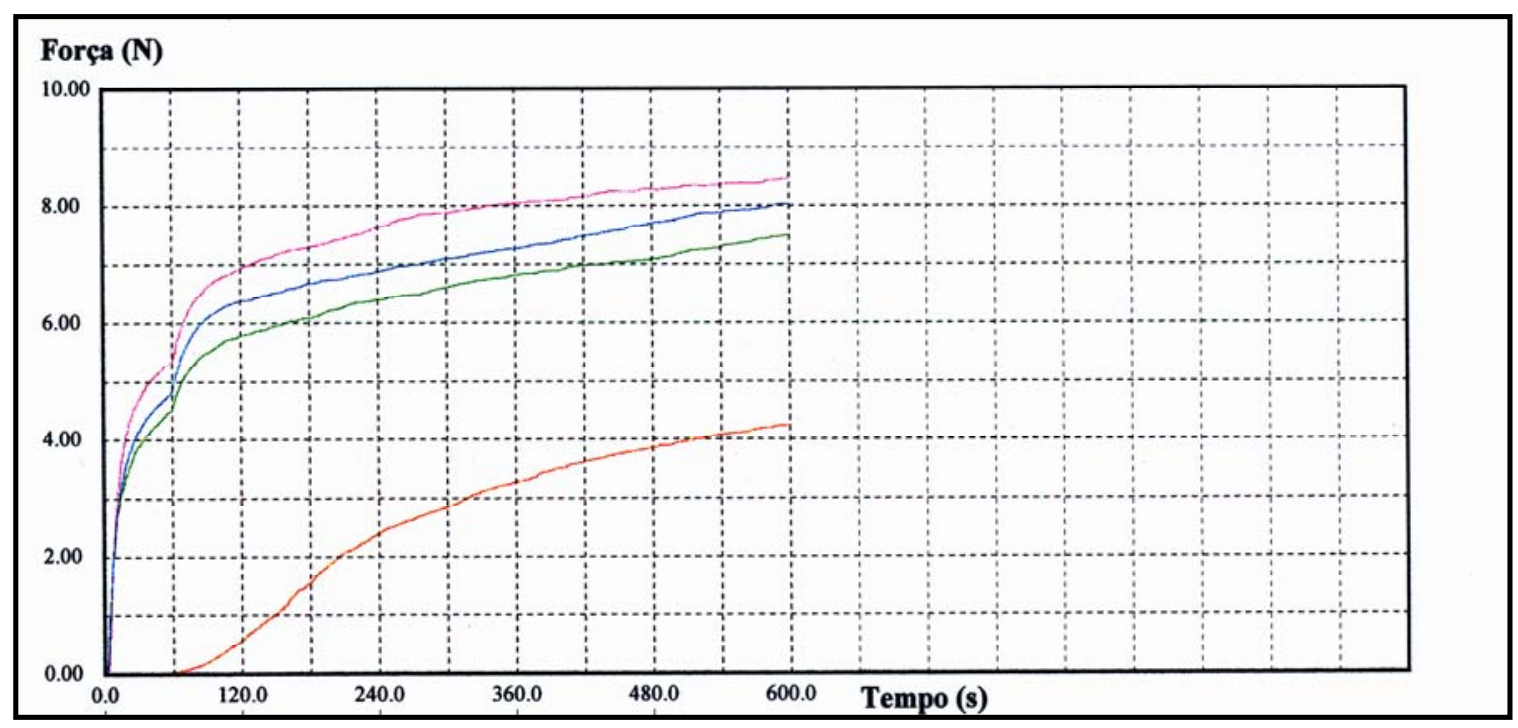

Figura 5.1 Curva força-tempo do comportamento médio mostrado por cada um dos quatro grupos avaliados (roxo Filtek A-110; Azul Filtek P-60; verde Filtek Z250 e vermelho Concise).

Os valores registrados foram submetidos à análise de variância a um criterio confirmando-se diferenças estatisticamente significativas entre os grupos avaliados $(p<0,05)$ (Tabela 5.1). No teste de Tukey para comparações múltiplas, os resultados mostraram que existiu um comportamento diferente para a resina quimicamente ativada em relação às fotoativadas. Concise apresentou forças de contração de polimerização com média de 4,216 $\pm 0,353 \mathrm{~N}$, sendo este valor significantemente inferior àqueles apresentados pelas resinas compostas fotoativadas $(p<0,05)$ (Tabela 5.1).

A resina de micropartículas Filtek A-110 apresentou a maior média dentre as resinas fotoativadas $(8,365 \pm 0,5956 \mathrm{~N})$, sem diferenças estatisticamente significativas da resina de alta viscosidade Filtek P-60 $(8,111 \pm 0,6868 N)(p>0,05)$ 
e com diferenças estatisticamente significativas em relação à resina composta microhíbrida Filtek Z-250 $(7,500 \pm 0,6149 N)(p<0,05)($ Tabela 5.1).

Tabela 5.1: Média (Newton), desvio padrão, coeficiente de variação e análise estatística das forças máximas registradas durante o período avaliado para a resina quimicamente ativada Concise e resinas fotoativadas Filtek A-110, Filtek Z250 e Filtek P-60.

\begin{tabular}{c|c|c|c|cc}
\hline Grupo & Média (N) & $\begin{array}{c}\text { Desvio Padrão } \\
(\mathrm{N})\end{array}$ & $\begin{array}{c}\text { Coeficiente de } \\
\text { Variação (\%) }\end{array}$ & $\begin{array}{c}\text { Análise } \\
\text { Estatística* }\end{array}$ \\
\hline Concise & 4,216 & 0,3536 & 8,386 & $\mathrm{a}$ & \\
\hline Filtek A-110 & 8,365 & 0,5956 & 7,120 & \multicolumn{2}{c}{$\mathrm{c}$} \\
\hline Filtek Z-250 & 7,500 & 0,6149 & 8,199 & \multicolumn{2}{c}{$\mathrm{b}$} \\
\hline Filtek P-60 & 8,111 & 0,6868 & 8,467 & \multicolumn{2}{c}{ b } \\
\hline
\end{tabular}

$n=10 ; p<0,05$;

*Letras diferentes significam valores estatisticamente diferentes.

5.2 Avaliação da influência da fonte de luz e densidade de potência sobre as forças de contração de polimerização de uma resina composta.

Os resultados mostraram, para todas as fontes de luz avaliadas, que as forças de contração de polimerização da resina composta microhíbrida Filtek Z250 aumentaram rapidamente assim que a fotoativação começou, para depois de aproximadamente 30 segundos diminuir a velocidade com que essas forças foram geradas. Quando a fonte de luz Ultrablue IS foi utilizada com ativação programada em rampa, não foi observado diferenças com a fonte de luz halógena no trajeto da curva nos primeiros segundos, em função da irradiação com baixa densidade de potência durante os primeiros 5 segundos $\left(200 \mathrm{~mW} / \mathrm{cm}^{2}\right)$ (Figura 5.2). Foi 
observado para a fonte de luz halógena e para o LED (Ultrablue IS) a 300 e 600 $\mathrm{mW} / \mathrm{cm}^{2}$ que, no momento da conclusão da fotoativação e por alguns segundos, aconteceu um novo incremento da velocidade com que as forças foram geradas $(\mathrm{N} / \mathrm{s})$, antes de voltar a diminuir novamente, evidenciado na curva força $x$ tempo como um trajeto em forma de "S". Esse incremento adicional não foi observado com a fonte de luz Ultraled, LED com a menor densidade de potência dos aparelhos avaliados (140 $\left.\mathrm{mW} / \mathrm{cm}^{2}\right)$ (Figura 5.2). Posteriormente os valores mostraram um aumento constante até o final do período avaliado (120 segundos) (Figura 5.2).

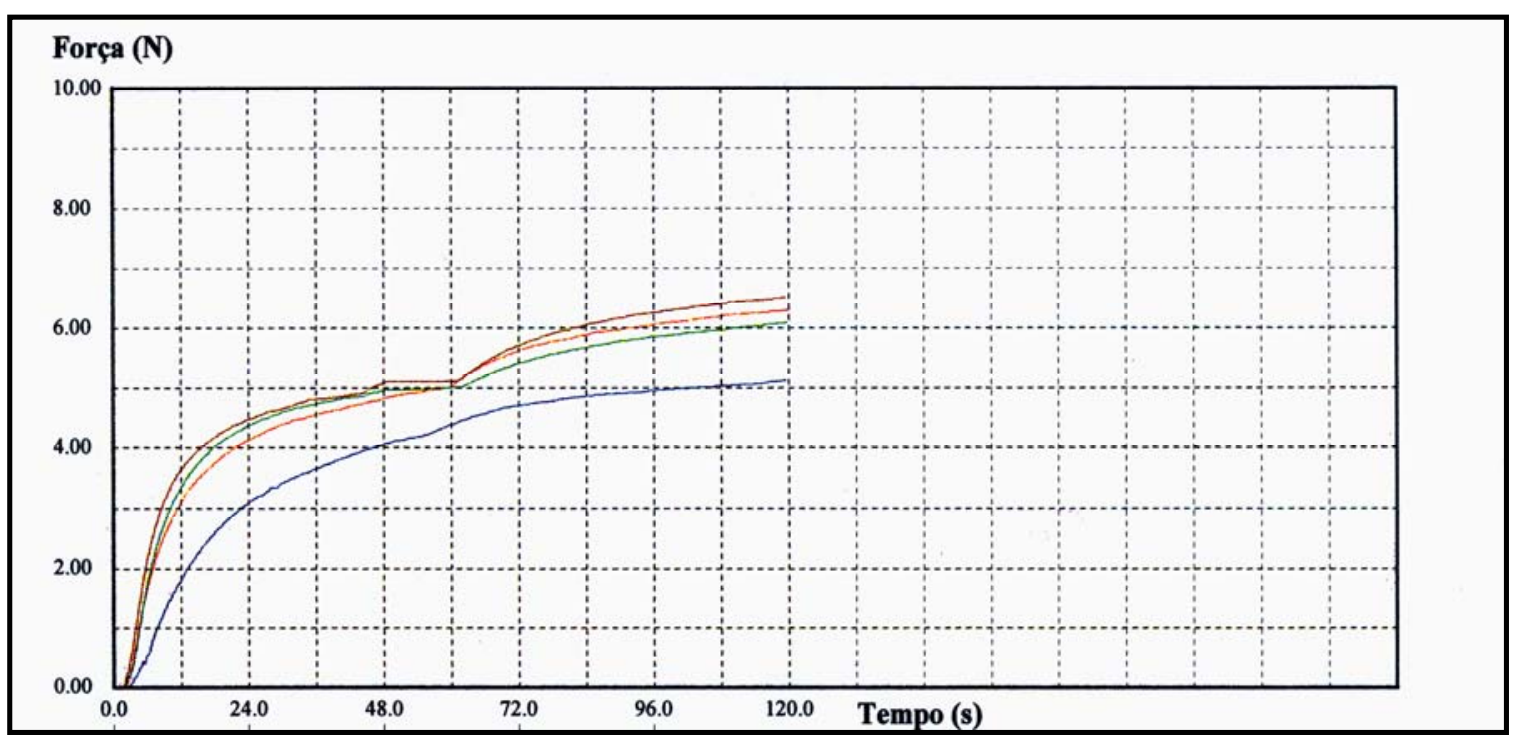

Figura 5.2: Curva força-tempo do comportamento da resina Filtek Z250 para os quatro grupos avaliados (marrom Ultrablue IS $600 \mathrm{mw} / \mathrm{cm}^{2}$; vermelho Spectrum; verde Ultrablue IS $300 \mathrm{mw} / \mathrm{cm}^{2}$ e azul Ultraled).

Os valores foram submetidos à análise de variância a um criterio e mostraram diferenças estatisticamente significativas entre os grupos avaliados (Tabela 5.2). No teste de Tukey, para comparações múltiplas, os resultados mostraram que o grupo polimerizado com a fonte de luz Ultraled apresentou media 
significantemente menor que os outros grupos avaliados $(5,175 \pm 0,3480 \mathrm{~N})$ $(p<0,05)$. O grupo polimerizado com Spectrum $(6,316 \pm 0,2175 N)$ não mostrou diferenças estatisticamente significativas com Ultrablue IS nas duas densidades de potência empregadas. Finalmente, os grupos fotoativados com a fonte de luz Ultrablue IS, a densidades de potência de 300 e $600 \mathrm{~mW} / \mathrm{cm}^{2}(6,108 \pm 0,2252 \mathrm{~N}$ e $6,497 \pm 0,2565 \mathrm{~N}$ respectivamente) apresentaram diferenças estatisticamente significativas $(p<0,05)($ Tabela 5.2$)$.

Tabela 5.2: Média (Newton), desvio padrão, coeficiente de variação e análise estatística das forças máximas registradas durante o período de 120 segundos para a resina composta Filtek Z-250 quando polimerizada com diferentes fontes de luz e densidades de potência.

\begin{tabular}{c|c|c|c|c}
\hline Grupo & Média (N) & $\begin{array}{c}\text { Desvio Padrão } \\
(\mathrm{N})\end{array}$ & $\begin{array}{c}\text { Coeficiente de } \\
\text { Variação (\%) }\end{array}$ & $\begin{array}{c}\text { Análise } \\
\text { Estatística* }^{*}\end{array}$ \\
\hline $\begin{array}{c}\text { Spectrum } \\
500 \mathrm{~mW} / \mathrm{cm}^{2}\end{array}$ & 6,316 & 0,2175 & 3,444 & $\mathrm{a}$ \\
\hline $\begin{array}{c}\text { Ultraled } \\
140 \mathrm{~mW} / \mathrm{cm}^{2}\end{array}$ & 5,175 & 0,3480 & 6,724 & $\mathrm{c}$ \\
\hline $\begin{array}{c}\text { Ultrablue IS } \\
300 \mathrm{~mW}_{\mathrm{cm}}\end{array}$ & 6,108 & 0,2252 & 3,687 & $\mathrm{~b}$ \\
\hline $\begin{array}{c}\text { Ultrablue IS } \\
600 \mathrm{~mW} / \mathrm{cm}^{2}\end{array}$ & 6,497 & 0,2565 & 3,948 & $\mathrm{a}$ \\
\hline $\mathrm{n}=10 ; \mathrm{p}<0,05 ;$
\end{tabular}

*Letras diferentes significam valores estatisticamente diferentes.

5.3 Avaliação das forças de Contração de Polimerização em função da utilização de materiais intermediários. 


\subsubsection{Teste A: Avaliação das forças de contração de polimerização do cimento de ionômero de vidro Vitrebond e da resina de baixa viscosidade Filtek Flow.}

As curvas descritas pelos materiais avaliados mostram claramente a diferença entre os valores de forças de contração, assim como a velocidade com que essas forças foram geradas. A curva média obtida pela resina composta Filtek Z-250 (controle) mostrou maior velocidade na formação de forças de contração de polimerização durante os primeiros 12 segundos. Após este momento inicial foi ultrapassada em magnitude e velocidade pelas forças geradas pela resina de baixa viscosidade Filtek Flow (Figura 5.3), tendência que se manteve até o final do teste. Entre os três materiais pode-se observar maior inclinação à direita na curva descrita pelo cimento de ionômero de vidro modificado por resina Vitrebond. Isto indica a menor velocidade com que as forças de contração foram geradas pelo Vitrebond, quando comparado com os materiais resinosos, assim como menor magnitude destas forças durante o período de 120 segundos (Figura 5.3).

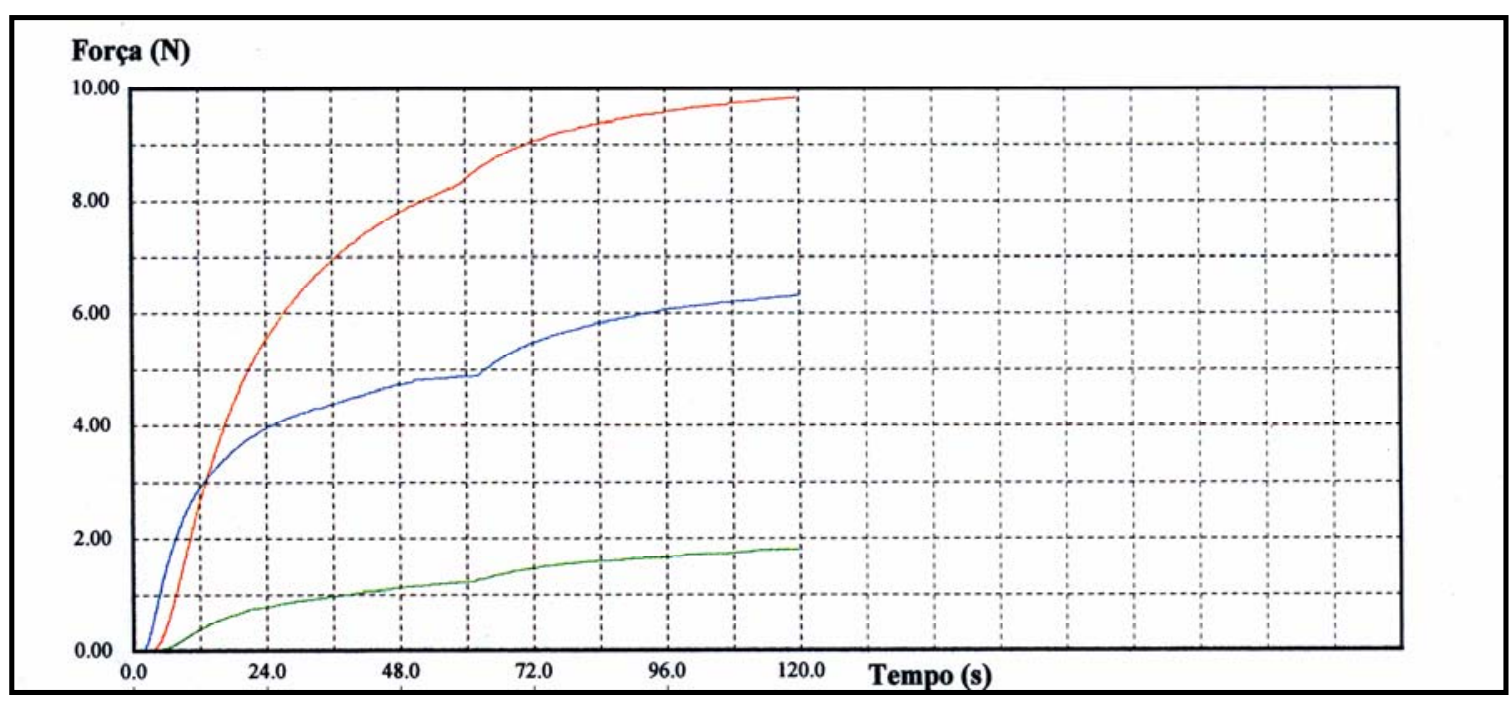

Figura 5.3 Curva força-tempo do comportamento médio mostrado por cada um dos três materiais avaliados (vermelho Filtek Flow; azul Filtek Z-250 e verde Vitrebond). 
A análise de variância mostrou a existência de diferenças estatisticamente significativas entre as forças de contração de polimerização dos materiais avaliados. No teste de Tukey pode-se observar que a resina de baixa viscosidade Filtek Flow, mostrou os maiores valores de forças de contração durante os 120 segundos do ensaio $(9,863 \pm 0,2977 N)$, sendo as diferenças com os outros materiais estatisticamente significativas (Tabela 5.3). Entre a resina composta FILTEK Z-250 (6,321 \pm 0,2618N) e o cimento de ionômero de vidro modificado por resina Vitrebond $(1,876 \pm 0,2308 \mathrm{~N})$ existiram diferenças estatisticamente significativas $(p<0,05)$ (Tabela 5.3). Pode-se notar o maior coeficiente de variação obtido no grupo do cimento de ionômero de vidro modificado por resina Vitrebond.

Tabela 5.3: Média (Newton), desvio padrão, coeficiente de variação e análise estatística das forças máximas registradas durante o período avaliado da resina composta Filtek Z-250, da resina de baixa viscosidade Filtek Flow e do cimento de ionômero de vidro modificado por resina Vitrebond em cada grupo.

\begin{tabular}{c|c|c|c|c}
\hline Grupo & Média (N) & $\begin{array}{c}\text { Desvio Padrão } \\
(\mathrm{N})\end{array}$ & $\begin{array}{c}\text { Coeficiente de } \\
\text { Variação (\%) }\end{array}$ & $\begin{array}{c}\text { Análise } \\
\text { Estatística* }\end{array}$ \\
\hline Filtek Z-250 & 6,321 & 0,2618 & 4,141 & $\mathrm{~b}$ \\
\hline Filtek Flow & 9,863 & 0,2977 & 3,019 & $\mathrm{c}$ \\
\hline Vitrebond & 1,876 & 0,2308 & 12,31 & $\mathrm{a}$ \\
\hline $\mathrm{n}=10 \mathrm{p}<0,05$ & \multicolumn{4}{|c}{}
\end{tabular}

*Letras diferentes significam valores estatisticamente diferentes. 
5.3.2. Teste B: Avaliação da transmissão das forças de contração de polimerização da resina composta Filtek Z-250 através de camadas com diferentes espessuras de cimento de ionômero de vidro modificado por resina Vitrebond e resina de baixa viscosidade Filtek Flow.

As curvas obtidas pelos diferentes materiais descreveram uma trajetória diferente durante o período avaliado, sendo que nos grupos 2 e 3 , que tiveram a resina de baixa viscosidade Filtek Flow como material intermediário, as forças de contração da resina composta Filtek Z-250 alcançaram maior magnitude rapidamente, evidenciando-se esse fato como uma inclinação mais vertical das curvas desses grupos em relação aos outros grupos avaliados (Figura 5.4).

Os grupos 4 e 5, que tiveram como material intermediário o cimento de ionômero de vidro modificado por resina Vitrebond mostraram, durante os primeiros 6 segundos, um comportamento similar ao grupo 1 (controle). A partir deste momento apresentaram uma inclinação à direita nas curvas, sendo mais evidente para o grupo 5 que empregou maior espessura do material intermediário. Esse comportamento da curva evidencia menor velocidade (N/s) na transmissão das forças geradas pela resina composta Filtek Z-250 através do Vitrebond (Figura $5.4)$. 


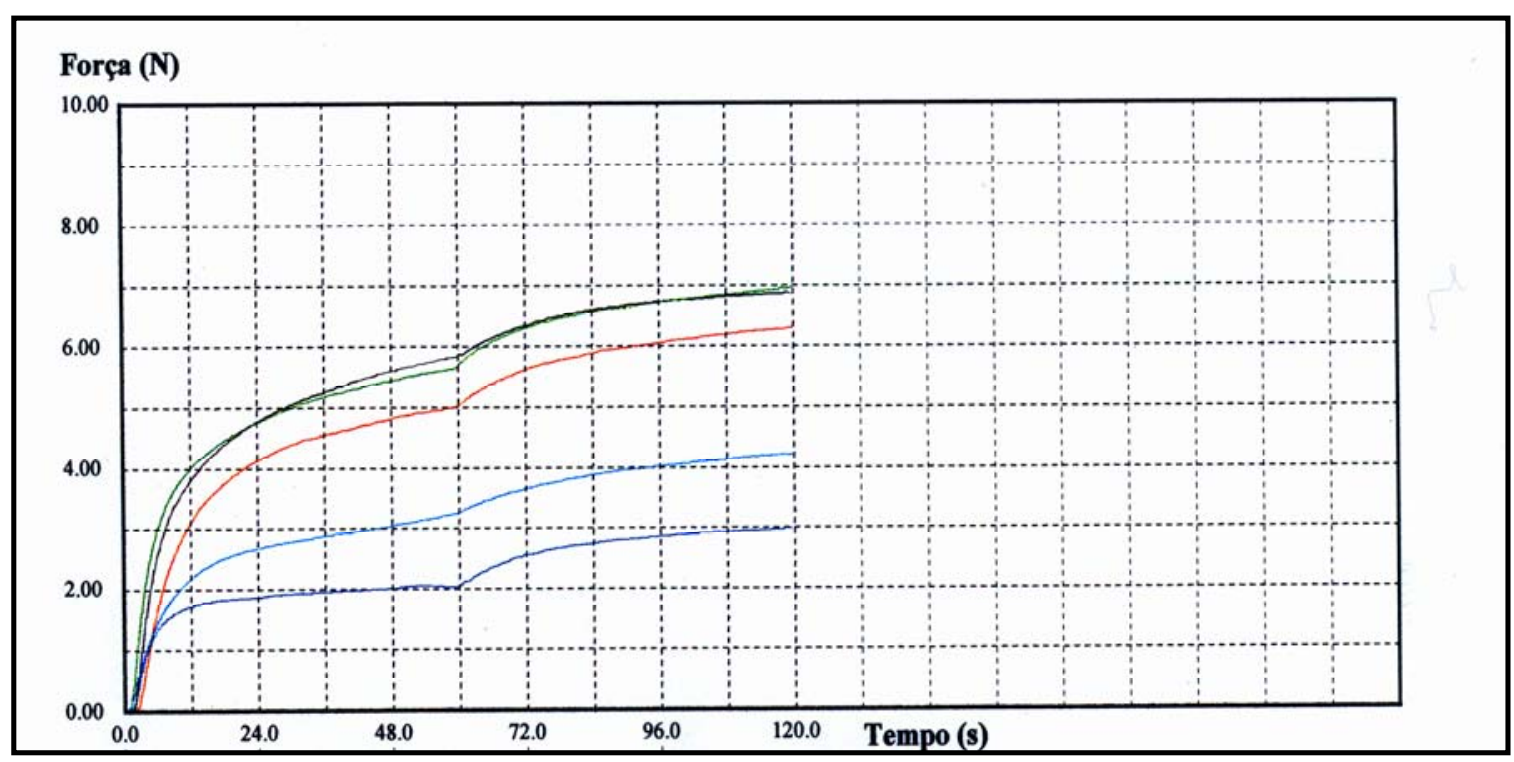

Figura 5.4 Curva força-tempo do comportamento médio apresentado para cada um dos cinco grupos avaliados (verde Filtek Z-250+ $1 \mathrm{~mm}$ de Filtek Flow; preto Filtek Z-250+ 0,5mm de Filtek Flow; vermelho Filtek Z-250; azul claro Filtek Z250+ 0,5mm de Vitrebond e azul Filtek Z-250+1 $\mathrm{mm}$ de Vitrebond).

Os resultados mostraram que existiram diferenças estatisticamente significativas entre os valores de forças de contração que foram registrados para a resina composta Filtek Z-250 com e sem material intermediário (Tabela 5.4).

O grupo 1, no qual a resina composta Filtek Z-250 foi utilizado sem material intermediário, mostrou forças de contração com média de 6,321 \pm 0,2618N. Quando o mesmo material foi utilizado com uma camada de resina de baixa viscosidade como material intermediário, o sistema restaurador apresentou valores significativamente maiores de forças de contração do que o grupo controle, independentemente da espessura da camada de material intermediário utilizada $(p<0,05)$ (Tabela 5.4). 
No grupo 2, onde a camada de Filtek Flow foi de $0,5 \mathrm{~mm}$ o valor médio das forças de contração do sistema restaurador foi de 6,868 $\pm 0,2391 \mathrm{~N}$, enquanto a camada de $1 \mathrm{~mm}$ de espessura promoveu para o grupo 3 um valor médio de 6,978 \pm 0,3684N (tabela 5.4). Mesmo apresentando-se diferenças entre os valores da média aritmética, estas não foram estatisticamente significativas ( $p>0,05)$.

Nos grupos 4 e 5, onde a resina composta Filtek Z-250 foi utilizada em conjunto com o cimento de ionômero de vidro modificado por resina Vitrebond como material intermediário, os valores das forças de contração de polimerização diminuiram significantemente. Uma camada de $0,5 \mathrm{~mm}$ de espessura de Vitrebond promoveu, no grupo 4, valor médio de 4,075 $\pm 0,4880 \mathrm{~N}$. Esse valor foi significantemente menor que o grupo 1 (controle) e os grupos 2 e 3, onde a resina de baixa viscosidade foi utilizada como material intermediário $(p<0,05)$ (Tabela $5.4)$.

O grupo 5, onde foi utilizada uma camada de $1 \mathrm{~mm}$ de Vitrebond, o mesmo apresentou valor médio de forças de contração de polimerização de 2,812 \pm 0,4894N, sendo esses valores, quando submetido à análise estatística, significantemente menores que os outros grupos avaliados, $(p<0,05)$ (Tabela 5.4). Pode-se notar novamente o maior coeficiênte de variação obtido nos grupos em que o cimento de ionômero de vidro modificado por resina Vitrebond esteve presente (Tabela 5.4). 
Tabela 5.4: Médias (Newton), desvio padrão, coeficiente de variação e análise estatística das forças de contração máximas registradas da resina composta Filtek Z-250 em cada grupo avaliado.

\begin{tabular}{|c|c|c|c|c|}
\hline Grupo & Média (N) & $\begin{array}{c}\text { Desvio Padrão } \\
(\mathrm{N})\end{array}$ & $\begin{array}{l}\text { Coeficiente de } \\
\text { Variação (\%) }\end{array}$ & $\begin{array}{c}\text { Análise } \\
\text { Estatística * }\end{array}$ \\
\hline $\begin{array}{l}\text { 1) } Z-250 \\
\text { (controle) }\end{array}$ & 6,321 & 0,2618 & 4,141 & C \\
\hline $\begin{array}{c}\text { 2) Z-250 + } \\
0,5 \mathrm{~mm} \text { FFlow }\end{array}$ & 6,868 & 0,2391 & 3,481 & d \\
\hline $\begin{array}{l}\text { 3) } \mathrm{Z}-250+ \\
\text { 1mm FFlow }\end{array}$ & 6,978 & 0,3684 & 5,280 & $\mathrm{~d}$ \\
\hline 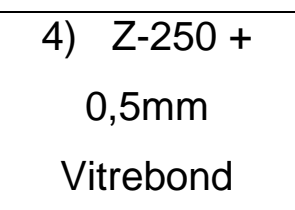 & 4,075 & 0,4880 & 11,97 & $\mathrm{~b}$ \\
\hline $\begin{array}{c}\text { 5) Z-250 + } \\
\text { 1mm Vitrebond }\end{array}$ & 2,812 & 0,4894 & 17,40 & 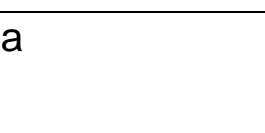 \\
\hline
\end{tabular}

*Letras diferentes significam valores estatisticamente diferentes. 
6. DISCUSSÃO 


\section{DISCUSSÃO}

\subsection{Metodologia}

Durante o processo de polimerização das resinas compostas, suas moléculas se situam mais perto uma das outras com a finalidade de formar cadeias de polímeros (HEGDAHL;GJERDET ${ }^{42}$, 1977; BAUSCH et $\mathrm{al}^{5}$, 1982; BRAGA; FERRACANE ${ }^{11}$, 2002). Como conseqüência deste reordenamento molecular, o material experimenta uma contração volumétrica que, em certas condições, quando o material é impedido de se contrair (como em uma restauração adesiva), são desenvolvidas forças em decorrência da falta de deformação na supefície externa da restauração (BOWEN ${ }^{8}$, 1967; HEGDAHL; GJERDET $^{42}$, 1977; BAUSCH et $\mathrm{al}^{5}$, 1982; DAVIDSON; DE GEE ${ }^{29}$, 1984;). Essas forças transmitem tensão à interface dente-restauração e podem ser responsáveis pelas falhas adesivas que podem causar fendas marginais, microinfiltração, sensibilidade pós operatoria, pigmentação e cárie secundária (DAVIDSON; DE GEE $^{29}$, 1984; DAVIDSON; FEILZER ${ }^{32}$, 1997). Por outro lado, não havendo falha adesiva, as forças de contração podem causar movimento das cúspides (MEREDITH; SETCHELL ${ }^{55}$, 1997; ALOMARI; REINHARDT; BOYER ${ }^{1}, 2001$ ), possível diminuição da resistência da estrutura dentária (DAVIDSON; FEILZER ${ }^{32}$, 1997) e até fraturas dentais (VERSLUIS; TANTBIROJN ${ }^{83}, 1999$ ).

As forças de contração de polimerização tem sido relacionadas com a contração volumétrica (HEGDAHL; GJERDET ${ }^{42}$, 1977; BOUSCHLICHER; VARGAS; BOYER $\left.{ }^{7}, 1997\right)$, capacidade de escoamento do material (DAVIDSON; DE GEE ${ }^{29}$, 1984; DAVIDSON; DE GEE; FEILZER ${ }^{31}$, 1984; CASTAÑEDAESPINOSA $^{13}, 1991$; CARVALHO et al. ${ }^{12}$, 1996), flexibilidade do material (KEMPSCHOLTE; DAVIDSON ${ }^{43}$, 1988; PRATI ${ }^{62}$, 1989; KEMP-SCHOLTE; DAVIDSON ${ }^{44}$, 1990; KEMP-SCHOLTE; DAVIDSON ${ }^{45}$, 1990; PRATI ${ }^{63}$, 1990; CASTAÑEDAESPINOSA $^{13}, 1991$;), deformação do equipamento utilizado no teste (DAVIDSON; DE GEE ${ }^{29}$, 1984; VERSLUIS et al. ${ }^{81}$, 1996; DAVIDSON; FEILZER ${ }^{32}$, 1997; 
MEREDITH; SETCHELL ${ }^{55}$, 1997), geometria da cavidade (FEILZER; DE GEE; DAVIDSON $^{34}$, 1987; BOUSCHLICHER; VARGAS; BOYER ${ }^{7}, 1997$; MIGUEL; DE LA MACORRA $^{56}, 2001$ ), tipo e velocidade de polimerização (UNO; ASMUSSEN ${ }^{79}$, 1991; FEILZER; DE GEE; DAVIDSON ${ }^{37}$, 1993; BOUSCHLICHER; VARGAS; BOYER $^{7}$, 1997; KORAN; KÜRSCHNER ${ }^{47}$, 1998; LOPES $^{53}$, 2004), técnica de inserção (DAVIDSON;DE GEE; FEILZER ${ }^{31}$, 1984; DAVIDSON ${ }^{25}$, 1986; CARVALHO et al. ${ }^{12}, 1996$; VERSLUIS et al. ${ }^{81}, 1996$ SUH $\left.^{74}, 2001\right)$ e vários fatores que podem modificar a cinética desse processo (CASTAÑEDA-ESPINOSA ${ }^{13}$, 1991; CARVALHO et al. ${ }^{12}, 1996 ;$ ).

Segundo SAKAGUCHI ${ }^{67}$ (1999), mesmo que as forças de contração sejam dos maiores problemas com as restaurações de resina composta, seu registro é muito complicado pois não pode ser realizado diretamente. Varios métodos tem sido desenvolvidos para determinar as forças de contração de polimerização transmitidas das resinas compostas para outros materiais. Foram utilizadas máquinas de ensaio universal (HEGDAHL; GJERDET ${ }^{42}$, 1977; DAVIDSON; DE GEE $^{29}$, 1984; FEILZER; DE GEE; DAVIDSON ${ }^{34}$, 1987; FEILZER; DE GEE; DAVIDSON $^{35}$, 1990; ALSTER et $\mathrm{al}^{2}$, 1997; BOUSCHLICHER; VARGAS; BOYER ${ }^{7}$, 1997; CONDON; FERRACANE ${ }^{23}$, 2000; CHEN et al. ${ }^{18}$, 2001; MIGUEL; DE LA MACORRA $^{56}$, 2001; CASTAÑEDA-ESPINOSA; MONDELLI ${ }^{14}, 2002$; ASENJOMARTINEZ et $\mathrm{al}^{3}, 2003$; AZEVEDO et al. $^{4}, 2003$; CAVALCANTI; CASTAÑEDAESPINOSA; MONDELLI ${ }^{15}$, 2003; SAKAGUCHI; WILTBANK; MURCHISON ${ }^{70}, 2004$ ) ou fotoelasticidade (KINOMOTO et $\mathrm{al}^{46}$, 1999; LOPES ${ }^{53}, 2004$ ). Outros métodos foram desenvolvidos para determinar a tensão de contração através da utilização de lâminas de tensão (SAKAGUCHI ${ }^{69}$, 1998; LOPES ${ }^{53}, 2004$ ), e simulações de testes em computador, como a análise do elemento finito (VERSLUIS et al. ${ }^{81}$, 1996).

Neste estudo foi desenvolvido um teste para a medição das forças de contração de polimerização, baseado no desenho de FEILZER; DE GEE; DAVIDSON $^{34}$ (1987), porém com modificações específicas, como a adoção de um 
corpo-de-prova retangular e não cilíndrico, diferentes dos utilizados na maioria dos trabalhos que empregaram máquina de ensaio universal (HEGDAHI; GJERDET ${ }^{42}$, 1977; DAVIDSON; DE GEE ${ }^{29}$, 1984; FEILZER; DE GEE; DAVIDSON ${ }^{34}$, 1987; KEMP-SCHOLTE; DAVIDSON ${ }^{44}$, 1990; ALSTER et $\mathrm{al}^{2}$, 1997; BOUSCHLICHER; VARGAS; BOYER ${ }^{7}, 1997$; MIGUEL; DE LA MACORRA $\left.{ }^{56}, 2001\right)$. Um corpo-deprova cilíndrico não permite a passagem uniforme da luz através dele, uma vez que a espessura de material que os fótons atravessam diminue do centro do corpo-de-prova para os extremos laterais. Conseqüentemente, a polimerização não acontece de maneira homogênea no material, e vetores de força poderiam-se formar em diferentes direções, permitindo mudar a leitura dos valores de força de contração, além da possibilidade de ter um material com menor grau de conversão em algumas áreas. Anteriormente $\mathrm{CHEN}$ et al. ${ }^{18}$, em 2001, utilizaram um corpo-deprova retangular com $32 \mathrm{~mm}^{3}$ de volume. Neste experimento os corpos-de-prova com $12 \mathrm{~mm}^{3}$ de volume diferem do utilizado por estes autores, sendo este volume mais próximo dos incrementos utilizados na técnica restauradora incremental. $A$ configuração das bases e, conseqüentemente, a forma retangular dos corpos-deprova proporcionam polimerização uniforme dos materiais avaliados, com espessura próxima de 2,0mm e comprimento de 6,0 $\mathrm{mm}$. Diferentemente dos trabalhos mencionados (FEILZER; DE GEE; DAVIDSON ${ }^{34}$, 1987; BOUSCHLICHER; VARGAS; BOYER ${ }^{7}$, 1997; CHEN et $\mathrm{al}^{18}$, 2001; FEILZER; DE GEE; DAVIDSON $\left.{ }^{37}, 1993\right)$, onde a espessura foi maior e foram utilizados até dois aparelhos fotoativadores gerando condições totalmente atípicas a um procedimento restaurador clínico, neste experimento a configuração das bases permitiu polimerização uniforme em todos os corpos-de-prova utilizando apenas uma fonte de luz.

É importante salientar que os resultados aqui obtidos apresentaram menores valores que alguns trabalhos publicados anteriormente, os quais empregaram volumes maiores de resina composta (FEILZER; DE GEE; DAVIDSON $^{34}$, 1987; ALSTER et al. $^{2}$, 1997; BOUSCHLICHER; VARGAS; BOYER $^{7}, 1997$; CHEN et $\left.\mathrm{al}^{18}, 2001\right)$ e semelhantes ao trabalho publicado por 
MIGUEL; DE LA MACORRA ${ }^{56}$, em 2001, onde menor volume de resina composta foi utilizado.

Uma das maiores dificuldades observadas em trabalhos de avaliação das forças de contração de polimerização é a grande quantidade de variáveis existentes na metodologia de diferentes trabalhos. DAVIDSON; FEILZER ${ }^{32}$ (1997) consideram que o equipamento utilizado no teste deve ser totalmente rígido para se conseguir avaliar as forças de contração de polimerização, acrescentando que um teste não rígido pode influir nos resultados de corpos-de-prova de diversos tamanhos e proporções diferentes. Explicaram que a influência de uma deformação constante do equipamento poderia ser maior para os corpos-de-prova de menor tamanho, enfatizando que esse fato poderia levar a interpretações erradas dos resultados de corpos-de-prova com diferentes alturas.

Outro ponto de vista apresentado por MIGUEL; DE LA MACORRA ${ }^{56}$ (2001) é que o equipamento usado para os testes de FEILZER; DE GEE; DAVIDSON ${ }^{34}$, em 1987 e FEILZER; DE GEE; DAVIDSON ${ }^{37}$, em 1993, não poderia ser considerado rígido, uma vez que os discos opostos estiveram constantemente se afastando quando a resina se contraia, de maneira a manter uma distânçia constante entre eles. No presente trabalho foi utilizado um sistema que pode ser considerado "não rígido", pelo fato do mesmo não apresentar um sistema de reposicionamento das bases metálicas confeccionadas em aço inoxidável, como aquele utilizado por FEILZER; DE GEE; DAVIDSON ${ }^{34}$ (1987) e FEILZER; DE GEE; DAVIDSON ${ }^{37}$ (1993). No entanto, durante os ensaios não foi permitido ao braço móvel da máquina de ensaio se movimentar para compensar a contração de polimerização dos materiais que foram aplicados entre as bases metálicas com altura constante de $1 \mathrm{~mm}$. As forças de contração de polimerização dos materiais avaliados foram determinados somente pela deformação da célula de carga de 10 kg utilizada. 
MEREDITH; SETCHELL ${ }^{55}$ (1997) registraram movimento de cúspides depois de restaurar cavidades com resina composta. Esse resultado demonstrou que em cavidades reais não existe um sistema totalmente rígido e a deformação das paredes cavitárias permite, proporcionalmente, maior liberação de tensões para os incrementos pequenos, em comparação com incrementos maiores, enfatizando a importância do volume utilizado em cada incremento e não a necessidade de um reposicionador na montagem do teste (BOUSCHLICHER; VARGAS; BOYER ${ }^{7}, 1997$; MIGUEL; DE LA MACORRA ${ }^{56}$, 2001).

\subsection{Resultados}

\subsubsection{Avaliação da influência do tipo de resina composta e modo de ativação sobre as forças de contração de polimerização.}

A resina composta quimicamente ativada foi espatulada e inserida no "espaço padrão" em um período de 120 segundos. Após esse período, iniciou-se o ensaio para registrar as forças de contração de polimerização do material. A resina Concise não apresentou forças de contração mensuráveis no período inicial de 60 segundos. Depois desse período inicial, o material primeiramente começou a gerar forças lentamente e logo com maior velocidade (N/s), por aproximadamente 300 segundos, para finalmente diminuir a velocidade nos últimos 240 segundos (Figura 5.1).

Esse comportamento pode ser observado pela inclinação da curva força/tempo, e explicado pela cinética de polimerização da resina quimicamente ativada, a qual experimentou um período aproximado de 180 segundos de fase pré-gel (120 segundos antes de iniciar o ensaio e 60 segundos registrados durante este). Nesse período a velocidade de polimerização é rápida mas o material ainda se apresenta em estado líquido, permitindo a deformação das superfícies livres do 
corpo-de-prova, de forma a liberar parte das tensões de contração (BAUSCH et al. $^{5}, 1982$; DAVIDSON; DE GEE ${ }^{29}$, 1984; FEILZER; DE GEE; DAVIDSON $\left.{ }^{36}, 1990\right)$. Quando o ponto de geleificação é atingido, o material começa a desenvolver forças de contração, primeiro em velocidade lenta, em função do baixo módulo de elasticidade do material e, logo após, com maior velocidade (BRAEM et al. ${ }^{10}$, 1987). Segundo estes autores, quando a reação de polimerização progride, o módulo de elasticidade da resina aumenta e a resina perde flexibilidade. Os resultados mostraram que a velocidade com que as forças de contração foram sendo geradas aumentou depois do período inicial, provavelmente em decorrência do material perder sua capacidade de absorver forças de contração através da deformação elástica (KEMP-SCHOLTE; DAVIDSON ${ }^{43}$, 1988; PRATI ${ }^{62}$, 1989; KEMP-SCHOLTE; DAVIDSON ${ }^{44}$, 1990). Nos últimos 240 segundos, a velocidade com que as forças de contração foram sendo geradas diminuiu, possivelmente em função da velocidade de polimerização ter diminuido por existir menor quantidade de monômeros disponíveis (BAUSCH et al. $^{5}$, 1982). A resina quimicamente ativada gerou forças de contração por todo o período avaliado. Durante a avaliação das resinas fotoativadas, forças foram desenvolvidas desde o início da fotoativação e durante todo o período avaliado, sendo a velocidade com que as forças foram geradas maior durante os 60 segundos que durou o procedimento de fotoativação. Resultados semelhantes foram obtidos por BOUSCHLICHER; VARGAS; BOYER ${ }^{7}$, em 1997, CHEN et al. ${ }^{18}$, em 2001, FEILZER; DE GEE; DAVIDSON ${ }^{37}$, em 1993, YAP et al. ${ }^{85}$, em 2000, e LOPES $^{53}$, em 2004.

Os resultados confirmam as observações de DAVIDSON; FEILZER ${ }^{29}$, que afrimaram em 1984 que grande parte das forças de contração de polimerização poderiam ser relaxadas através do escoamento do material, na superfície livre do corpo-de-prova, durante a fase pré-gel. Essa afirmação foi demonstrada para a resina quimicamente ativada Concise, mas com as resinas fotoativadas a possibilidade destas de relaxar as forças de contração através do escoamento do material é diminuída consideravelmente devido a sua fase pré-gel apresentar duração extremamente curta. Estes mesmos autores definiram o ponto de 
geleificação como o momento em que a resina começa a gerar forças de contração de polimerização (SAKAGUCHI ${ }^{67}$, 1999). Essa poderia ser a explicação para os maiores valores de forças de contração de polimerização obtidos para todas as resinas fotoativadas em relação à resina quimicamente ativada, onde a polimerização desta é mais lenta e a fase pré-gel mais longa (FEILZER; DE GEE; DAVIDSON ${ }^{37}$, 1993; BOUSCHLICHER; VARGAS; BOYER ${ }^{7}, 1997$; LOPES $^{53}$, 2004). Poderia ser importante avaliar o fator $C$ em resinas fotoativadas, pois o mesmo depende da capacidade de escoamento da resina composta na superfície livre do corpo-de-prova durante a fase pré-gel e, não necessariamente, mostrará o mesmo comportamento que as resinas quimicamente ativadas como foi observado, em 1997, por BOUSCHLICHER; VARGAS; BOYER ${ }^{7}$.

As resinas compostas geraram e armazenaram forças de contração de polimerização, mesmo depois de concluida a fotoativação. Resultados semelhantes foram registrados por DAVIDSON; FEILZER ${ }^{29}$, em 1984, FEILZER; DE GEE; DAVIDSON ${ }^{37}$, em 1993, BOUSCHLICHER; VARGAS; BOYER ${ }^{7}$, em 1997, YAP et $\mathrm{al}^{85}$, em 2000, MIGUEL; DE LA MACORRA ${ }^{56}$, em 2001, CHEN et $\mathrm{al}^{18}$, em 2001, CAVINA ${ }^{16}$, em 2003 e, LOPES ${ }^{53}$, em 2004. Esses resultados sugerem que, na técnica incremental de aplicação de resina composta, as tensões que são transmitidas à estrutura dentaria a partir de cada incremento de material, são acumulativas. Baseados em resultados semelhantes obtidos em trabalhos de análise do elemento finito, VERSLUIS; DOUGLAS; SAKAGUCHI ${ }^{81}$ (1996) afirmaram que a técnica incremental pode ser necessária para a adaptação, densificação, profundidade de polimerização e formação da adesão, mas não pelo efeito da contração de polimerização. MEREDITH; SETCHELL ${ }^{55}$ (1997) avaliaram, durante 600 segundos, a existência de tensões nas cúspides e movimentação destas quando o dente foi restaurado com resina composta. Os resultados revelaram uma situação complexa onde deve-se comprender que durante a confecção de uma restauração de resina composta, o material restaurador gera e armazena forças de contração de polimerização por um período de tempo indeterminado, e que essas forças transmitem tensões para a interface dente- 
restauração que podem levar às falhas adesivas por fadiga. Provavelmente, a única maneira clinicamente relevante de liberar tensões provenientes das forças de contração de polimerização das resinas compostas seja através da absorção de água pelo material e, conseqüentemente sua expansão higroscópica (HANSEN; ASMUSSEN $^{41}$, 1989; FEILZER; DE GEE; DAVIDSON ${ }^{35}$, 1990; CARVALHO et al. $\left.{ }^{12}, 1996 ;\right)$.

Como foi observado por CHEN et al. ${ }^{18}$ (2001), as curvas força/tempo descreveram uma trajetória em forma de "S" para as resinas fotoativadas (Figura 5.1). A maior velocidade (N/s) com que as forças de contração de polimerização foram geradas foi observada durante o início da fotoativação diminuindo durante os últimos segundos desse procedimento, o que evidencia diminuição na velocidade de polimerização do material. Imediatamente após a finalização da fotoativação, a velocidade com que as forças de contração foram sendo geradas aumentou rapidamente, por aproximadamente 60 segundos, para logo voltar a diminuir e continuar gerando forças durante todo o período avaliado (Figura 5.1). CHEN et al. ${ }^{18}$ (2001) explicaram a forma de "S" da curva como conseqüência da contração das resinas compostas, em decorrência da diminuição de temperatura no desligamento da luz.

Em relação ao tipo de resina composta, os resultados mostraram que a resina de micropartículas Filtek A-110 desenvolveu maiores forças de contração de polimerização do que a microhíbrida Filtek Z-250 e de alta viscosidade Filtek P60. Menores valores para a resina de micropartículas eram esperados em função do seu baixo módulo de elasticidade (7Gpa), porém sua maior contração volumétrica deve ser considerada (2.4\%). Os menores valores foram obtidos com Filtek Z-250, uma resina composta mais rígida (11Gpa), porém com menor contração volumétrica (2.2\%). Filtek P-60 é ainda um material mais rígido (12 Gpa), mas apresenta menor conteúdo orgânico que Filtek A-110 e experimenta menor contração volumétrica (2.2\%). Poderíamos responsabilizar os altos valores 
de forças de contração de Filtek A-110 em relação a Filtek Z-250 e Filtek P-60 à alta contração volumétrica, enquanto que o responsável pelos maiores valores observados para a Filtek P-60 em relação a Filtek Z-250 seria o maior módulo de elasticidade da primeira, desde que ambas apresentam a mesma contração volumétrica. Este resultado indica as limitações de um material de alta rigidez para conseguir absorver tensões através da flexibilidade do material. A transferência de tensões de contração de polimerização é dependente das propriedades físicas de cada resina composta e, principalmente de sua contração volumétrica e de seu módulo de elasticidade, como foi observado no presente trabalho (KEMPSCHOLTE; DAVIDSON $\left.{ }^{43}, 1988\right)$.

\subsubsection{Avaliação da influência da fonte de luz e densidade de potência sobre as forças de contração de polimerização de uma resina composta.}

Os resultados deste estudo mostraram que existiu influência da fonte de luz e da densidade de potência empregados sobre os valores de forças de contração de polimerização da resina composta Filtek Z-250 (Tabela 5.2). Trabalhos realizados com outras metodologias, onde foi comparado o efeito de diferentes fontes de luz sobre algumas propriedades físicas, no intuito de verificar a influência sobre o grau de polimerização, observaram diferenças entre a polimerização obtida com fonte de luz halógena e LED (MILLS; JANDT; ASHWORTH $^{57}$, 1999; KURACHI et al. ${ }^{49}$, 2001; LEONARD et al. ${ }^{51}$, 2002).

Segundo RUEGGEBERG; TAMARASELVY ${ }^{65}$ (1995) é possível determinar o grau de conversão das resinas compostas através da contração de polimerização. Desta maneira, pode-se supor que, quanto maior a força de contração do material, maior o seu grau de conversão. No entanto, existem outras variáveis que devem ser consideradas, como a capacidade do material de liberar 
tensões durante sua fase pré-gel (DAVIDSON; DE GEE ${ }^{29}$, 1984), e se o emprego de uma irradiação inicial reduzida diminuiria a contração pós-gel, mas mantendo o grau de conversão da resina (UNO; ASMUSSEN ${ }^{79}$, 1991; SAKAGUCHI; BERGER $\left.^{68}, 1998\right)$.

Neste trabalho foi observado que o grupo 2, onde a resina foi fotoativada com Ultraled $\left(140 \mathrm{~mW} / \mathrm{cm}^{2}\right)$, apresentou a menor velocidade de formação das forças de contração de polimerização, evidenciado pela inclinação à direita da curva força/tempo (Figura 5.2). Esse grupo também apresentou os menores valores de forças de contração de polimerização dentre os avaliados (Figura 5.2). A menor velocidade de polimerização, em função da menor densidade de potência da fonte de luz, aparentemente prolongou o período pré-gel do material, permitindo maior deformação e liberação das tensões, por um tempo mais longo que dos outros grupos, explicando sua menor média (DAVIDSON; DE GEE ${ }^{29}$, 1984; ASENJO-MARTINEZ et al. ${ }^{3}$, 2003; AZEVEDO et al. ${ }^{4}, 2003$; SAKAGUCHI; WILTBANK; MURCHISON $\left.{ }^{70}, 2004\right)$.

Por outro lado, mesmo que o tempo de fotoativação tenha sido maior àquele indicado para seu uso clínico (60 segundos), deve-se considerar a possibilidade de um menor grau de conversão deste grupo, em função da baixa densidade de energia irradiada, fato que também poderia explicar os menores valores de forças de contração de polimerização (RUEGGEBERG; TAMARESELVY ${ }^{65}$, 1995). Segundo KORAN; KÜRSCHNER ${ }^{47}$ (1998) e RUEGGEBERG ${ }^{64}$ (1999), uma densidade de energia de $16 \mathrm{~J} / \mathrm{cm}^{2}$ é suficiente para garantir a polimerização adequada do material com fonte de luz halógena. A densidade de energia do grupo irradiado com Ultraled, fonte de luz LED de baixa densidade de potência, foi de $8,4 \mathrm{~J} / \mathrm{cm}^{2}$, valor menor àquele requerido para fontes de luz halógenas. Por outro lado, a especificidade da luz produzida pelas fontes de luz LED teoricamente seria maior para a canforoquinona (MILLS;JANDT; ASHWORTH ${ }^{57}$, 1999; KURACHI et al. ${ }^{49}$, 2001; LEONARD et al. ${ }^{51}, 2002$ ), sendo 
que foi observado por LEONARD et al. ${ }^{51}$, em 2002, que 78\%, 84\%, 87\% e 95\% do espectro de emissão de quatro fontes de luz LED estiveram entre 450-500 nm, contra 56\% do espectro de emissão da fonte de luz halógena Optiluz 401. MILLS; JANDT; ASHWORTH ${ }^{57}$ (1999), observaram que 95\% da luz emitida por uma fonte de luz LED estaria dentro do comprimento de onda de 410 a 500nm, enquanto que para a fonte de luz halógena esse valor seria de 85\%, não achando uma diferença tão grande como aquela achada no trabalho de LEONARD et al. ${ }^{51}$ (2002). CAVINA et al. $^{17}$ (2003) observaram que resinas compostas polimerizadas com fonte de luz LED com densidade de energia de $10 \mathrm{~J} / \mathrm{cm}^{2}$ geraram maiores forças de contração de polimerização que as polimerizadas com $5 \mathrm{~J} / \mathrm{cm}^{2}$, porém não foram observadas diferenças estatisticamente significativas quando foram polimerizadas com densidades de energia de 15 e $20 \mathrm{~J} / \mathrm{cm}^{2}$. Os autores sugeriram que a fonte de luz LED Ellipar Freelight com $500 \mathrm{~mW} / \mathrm{cm}^{2}$ de densidade de potência e um tempo de 20 segundos $\left(10 \mathrm{~J} / \mathrm{cm}^{2}\right)$ pode estar obtendo uma polimerização aceitável. Ao observar a curva força/tempo do grupo polimerizado com Ultraled (Figura 5.2), pode-se verificar que a velocidade com que as forças de contração foram geradas diminuiu consideravelmente após 35 segundos e continuou a cair com poucas mudanças nos últimos 24 segundos, o que pode significar diminuição na velocidade de polimerização. Isto poderia sugerir que o material teria-se polimerizado adequadamente ou a ausência de monômero ativado disponível para iniciar novas cadeias de polímero (RUEGGEBERG; TAMARASELVY ${ }^{65}$, 1995; BRAGA; FERRACANE ${ }^{11}$, 2002;).

Foi observado durante a irradiação da resina composta com a fonte de luz Ultraled que as curvas das forças de contração de polimerização não apresentaram grande mudança na trajetória, no momento que a luz foi desligada, diferentemente dos outros grupos avaliados (Figura 5.2). Esta mudança na trajetória da curva foi relacionada à contração do material, produto de seu esfriamento após ter sido aquecido pela luz do aparelho fotoativador (CHEN et al. $^{18}$, 2001; SAKAGUCHI; WILTBANK; MURCHISON ${ }^{70}$, 2004). A menor mudança na trajetória da curva pode indicar menor aumento de temperatura do material e, 
conseqüente, menor contração durante o resfriamento, produto de uma luz mais "fria" como foi sugerido por CASTAÑEDA-ESPINOSA; MONDELLI ${ }^{14}$ (2002) e YAP; $\mathrm{SOH}^{84}$ (2003). Teoricamente, a luz mais fria seria conseqüência do seu comprimento de onda situado entre 450 e 500 nm, emitindo poucos fótons na área infravermelha onde o calor é rapidamente gerado. No entanto, quando os grupos foram fotoativados com Ultrablue IS, LED com densidade de potência de 300 e $600 \mathrm{~mW} / \mathrm{cm}^{2}$, pode-se observar alterações mais evidentes na curva força/tempo no momento de finalizar a fotoativação, similar àquela observada com fonte de luz halógena (Figura 5.2). Ao se calcular a densidade de energia pode-se verificar valores de $18 \mathrm{~J} / \mathrm{cm}^{2}$ e $36 \mathrm{~J} / \mathrm{cm}^{2}$ para os grupos irradiados com LED's a 300 e 600 $\mathrm{mW} / \mathrm{cm}^{2}$, respectivamente, e $30 \mathrm{~J} / \mathrm{cm}^{2}$ para o grupo irradiado com fonte de luz halógena a $500 \mathrm{~mW} / \mathrm{cm}^{2}$. SAKAGUCHI; WILTBANK; MURCHISON ${ }^{70}$, em 2004, observaram que, o emprego de fonte de luz halógena com baixa densidade de potência $\left(100 \mathrm{~mW} / \mathrm{cm}^{2}\right)$ e energia $\left(6 \mathrm{~J} / \mathrm{cm}^{2}\right)$ não promovia mudança da trajetória da curva, enquanto para os grupos com maior densidade de potência a mudança da trajetória da curva foi evidente, especialmente no grupo irradiado com 600 $\mathrm{mW} / \mathrm{cm}^{2}$ com densidade de energia de $36 \mathrm{~J} / \mathrm{cm}^{2}$. Essa observação poderia sugerir que, além do comprimento de onda, a densidade de potência e a energia de ativação são responsáveis pela transmissão de calor para o material.

O grupo polimerizado com fonte de luz halógena de $500 \mathrm{~mW} / \mathrm{cm}^{2}\left(30 \mathrm{~J} / \mathrm{cm}^{2}\right)$ não foi diferente estatisticamente aos grupos ativados com fonte de luz LED de $300 \mathrm{~mW} / \mathrm{cm}^{2}\left(18 \mathrm{~J} / \mathrm{cm}^{2}\right)$ e $600 \mathrm{~mW} / \mathrm{cm}^{2}\left(36 \mathrm{~J} / \mathrm{cm}^{2}\right)$, porém existiu diferença estatisticamente significante entre estes dois últimos grupos (Tabela 5.2). Neste trabalho o comportamento das forças de contração de polimerização esteve mais relacionadas com a densidade de potência do aparelho fotoativador, e correspondente densidade de energia, do que com o tipo de fonte de luz empregado (Tabela 5.2). 


\subsubsection{Avaliação das forças de Contração de Polimerização em função da utilização de materiais intermediários.}

As forças de contração de polimerização foram determinadas para a resina composta Filtek Z-250, quando utilizada como material único, ou quando combinado com a resina de baixa viscosidade Filtek Flow ou com o cimento de ionômero de vidro modificado por resina Vitrebond como materiais intermediários. Os resultados dos grupos onde o Vitrebond foi utilizado apresentaram valores menores que os outros grupos, sendo as diferenças estatisticamente significativas. Esses valores foram ainda menores quando a espessura utilizada da camada de Vitrebond foi de $1 \mathrm{~mm}$ (Figura 5.4 e Tabela 5.4). KEMP-SCHOLTE; DAVIDSON ${ }^{45}$ (1990) observaram liberação das tensões de contração de polimerizaçãona ordem de $18 \%$ a $50 \%$, quando uma camada de $0,15 \mathrm{~mm}$ de Vitrebond era aplicada embaixo dos corpo-de-prova com $5 \mathrm{~mm}$ de espessura da resina composta quimicamente ativada P-10. Mesmo que no presente estudo foi utilizado camadas de Vitrebond com diferentes espessuras e uma resina fotoativada, os resultados concordam com os obtidos por KEMP-SCHOLTE; DAVIDSON ${ }^{45}$ (1990), em relação à capacidade deste material em absorver as tensões de contração de polimerização. Os menores valores obtidos com a camada de Vitrebond de $1 \mathrm{~mm}$ quando comparada com a camada de 0,5mm, estão de acordo com UNTERBRINK; LIEBENBERG ${ }^{80}$ (1999), onde afirmaram que para determinado material com módulo de elasticidade específico, uma camada de maior espessura absorveria maiores tensões.

No desenho do teste, os materiais intermediários foram polimerizados alguns minutos antes do início do ensaio, para evitar a somatória da contração de polimerização destes. Embora Vitrebond apresente uma dupla reação de endurecimento, a reação de polimerização, por meio da ativação com fonte de luz, é responsável pelas propriedades físicas iniciais, incluindo a contração de polimerização (MITRA $\left.{ }^{58}, 1991\right)$. O volume e fator de configuração da resina 
composta Z-250 foram mantidos constantes para todos os grupos. Sendo assim, a possível explicação para os menores valores de força de contração de polimerização observados nos grupos em que Vitrebond foi utilizado, esta relacionado com a sua capacidade de absorver parte das forças geradas pela resina composta Filtek Z-250 (KREJCI;LUTZ; KREJCl ${ }^{48}$, 1988; TOLIDIS; NOBERCOURT; RANDALL ${ }^{78}$, 1998; DAVIDSON; DE GEE ${ }^{30}$, 2000). Essa absorção de tensões provavelmente é responsável pela diminuição dos valores das médias em porcentagens de 35,5\% (4,075N) e 55,5\% (2,812N) para os grupos com camadas de $0,5 \mathrm{~mm}$ e $1 \mathrm{~mm}$, respectivamente. DAUVILLIER et al. ${ }^{24}$ (2000) demonstraram que o módulo de elasticidade dos cimentos de ionômero de vidro aumenta de forma mais lenta que das resinas compostas. Isto explica sua maior capacidade de absorção de tensões, durante os primeiros minutos após a mistura dos componentes, como foi observado no presente estudo. Os maiores valores no coeficiente de variação dos grupos onde o Vitrebond foi utilizado pode estar relacionados à mistura do pó e líquido, além da possibilidade de mudanças na proporção ou inclusão de bolhas na mistura.

As resinas de baixa viscosidade apresentam propriedades físicas fracas, quando comparadas com as resinas híbridas, sofrem maior contração volumétrica, possuem maior coeficiente de expansão térmica e não são indicadas para serem utilizadas em áreas de alto estresse mecânico (UNTERBRINK; LIEBENBERG ${ }^{80}$, 1999). LABELLA et al. ${ }^{50}$ (1999) afirmaram que a maior contração de polimerização observada nas resinas de baixa viscosidade em relação às resinas compostas híbridas poderia estar indicando maior potencial em criar tensões interfaciais. Porém, como camada intermediária, seu proposto mecanismo de reduzir a microinfiltração é relacionado com sua relativa alta elasticidade, que poderia compensar o estresse de contração de polimerização da resina composta HAGGE et al. $^{40}$ (2001). Embora estes materiais sejam considerados de baixo módulo de elasticidade (UNTERBRINK; LIEBENBERG ${ }^{80}$, 1999) e, por esse motivo, uma diminuição das forças de contração de polimerização geradas pela resina composta poderia ser esperada, no presente estudo isso não aconteceu. Os 
resultados mostraram que, independentemente da espessura da camada utilizada, os grupos onde Filtek Flow foi utilizado apresentaram maiores valores de forças de contração de polimerização do que o grupo onde Filtek Z-250 foi utilizado como material único ou em combinação com Vitrebond (Figura 5.4).

A contração volumétrica e o módulo de elasticidade devem ser analizados de maneira dinâmica, em função que agem ao mesmo tempo e independentemente, e seus efeitos sobre as forças de contração são contrários (ALSTER et $\mathrm{al}^{1}$, 1997; UNTERBRINK; LIEBENBERG ${ }^{80}$, 1999; LABELLA et al. ${ }^{50}$, 1999; CHO et al. ${ }^{19}$, 2002). No desenho Do presente experimento, como já foi observado, o material intermediário foi polimerizado minutos antes da inserção da resina composta e o inicio do ensaio, procurando reproduzir a situação clínica. $O$ ensaio e a fototivação da resina composta Filtek Z-250 começaram simultaneamente. Embora a fotoativação da resina de baixa viscosidade tenha sido concluida antes do início do ensaio, esse material continuou gerando forças de contração residuais por alguns minutos. Isto pode ser observado na avaliação das forças de contração da resina de baixa viscosidade. Filtek Flow mostrou os maiores valores $(9,863 \pm 0,2977 \mathrm{~N})$ em relação aos outros materiais avaliados, sendo que estes valores foram obtidos ao final dos 120 segundos, tempo de duração do ensaio (Figura 5.3).

Considerando-se que a resina de baixa viscosidade deveria absorver parte das tensões geradas pela resina composta, em decorrência do seu baixo módulo de elasticidade, os valores apresentados pelos grupos 2 e 3 devem ser interpretados como o resultado da somatória das forças de contração de polimerização da resina composta Filtek Z-250 e da contração de polimerização residual da Filtek Flow. No presente estudo as forças de contração de polimerização da resina Filtek Flow foram tão altas que sobrepuseram as vantagens que a mesma poderia oferecer com seu baixo módulo de elasticidade (LABELLA et al. $\left.{ }^{50}, 1999\right)$, promovendo valores significantemente maiores do que o 
grupo controle, onde a resina Filtek Z-250 foi utilizada como material único. Desta maneira, considerando que as forças de contração resultantes dos grupos com Filtek Flow foram maiores e que essas forças poderiam prejudicar a adesão às paredes da cavidade (DAVIDSON; DE GEE ${ }^{31}$, 1984), pode-se esperar que um sistema restaurador com essas características apresente maior potencial para promover microinfiltração, em relação a restaurações confeccionadas sem resina de baixa viscosidade como material intermediário. HAGGE et al. ${ }^{40}$, em 2001 , observaram que a resina de baixa viscosidade Revolution, utilizada como material intermediário, não consegiu diminuir os valores de microinfiltração em relação à restaurações de resina composta como material único. Nesse trabalho foi observado que Fuji II LC, um cimento de ionômero modificado por resina, apresentou menores valores de microinfiltração que os grupos restaurados com resinas. Por sua vez, BEZNOS ${ }^{6}$ (2001) observou que, nem o cimento de ionômero de vidro modificado por resina, nem a resina de baixa viscosidade tiveram a capacidade de eliminar de forma total e sistemática a microinfiltração nas margens de dentina ou cemento em restaurações de resina composta, porém o autor notou uma tendência para piores resultados com a resina de baixa viscosidade.

No presente trabalho, não se observaram diferenças estatisticamente significativas entre os grupos com diferentes espessuras da camada de resina de baixa viscosidade. Esses resultados poderiam ser explicados pela afirmação feita por UNTERBRINK; LIEBENBERG ${ }^{80}$, em 1999, que uma camada de maior espessura apresentaria maior volume de material e conseqüentemente maior contração volumétrica, porém também aumentaria a capacidade de absorção de tensões dessa camada. MALMSTRÖM et al. ${ }^{54}$ (2002) acharam diferenças estatisticamente significativas quando compararam a microinfiltração de restaurações de resina composta com camadas de resina de baixa viscosidade com espessuras de 2,0mm e 0,5mm, em margens de esmalte. Quando a margem situada em dentina foi avaliada não acharam diferenças significantes na microinfiltração, mesmo quando as camadas de $0,5 \mathrm{~mm}$ e $1,0 \mathrm{~mm}$ foram 
comparadas. Esses resultados estariam de acordo com nossas observações, em relação à espessura de camada utilizada e ausência de diferenças significantes.

O Vitrebond pode ser considerado um material de baixo módulo de elasticidade e, diferentemente das resinas de baixa viscosidade, gerou poucas forças de contração de polimerização $(1,876 \mathrm{~N})$. Essa característica permitiu que a capacidade de absorção de tensões, decorrente de seu baixo módulo de elasticidade, possa ser evidenciada como diminuição das forças de contração dos grupos onde foi utilizado (Figura 5.4). Esses achados podem explicar, até certo grau, a melhor adaptação marginal (KREJCl; LUTZ; KREJCl ${ }^{48}, 1988$; DIETRICH et al. $^{33}$, 1999), menor microinfiltração (HAGGE et al. ${ }^{40}, 2001$; TAPETY $^{76}$, 2001) e menor movimentação de cúspides (ALOMARI; REINHARDT; BOWEN ${ }^{1}, 2001$ ) observadas em trabalhos com restaurações de resina composta que utilizaram ionômero de vidro como material intermediário.

A utilização de resinas de baixa viscosidade como material intermediário no intuito de diminuir as forças de contração de polimerização do sistema restaurador, em função de sua capacidade de absorção de tensões, poderia ser qüestionada em função da contração volumétrica residual, no momento que a resina composta é polimerizada, ainda ser alta o suficiente para promover aumento das forças de contração resultantes. Outros estudos sobre essa relação e outras propriedades desses materiais deveriam ser realizados, desde que existem trabalhos mostrando que algumas resinas de baixa viscosidade podem diminuir a microinfiltração de restaurações de resina composta (PAYNE IV ${ }^{61}$, 1999).

Por outro lado, baseado nos resultados deste trabalho que mostraram a capacidade de absorção de tensões do cimento de ionômero de vidro Vitrebond, poderia ser recomendável utilizá-lo como material intermediário sob restaurações 
de resina composta em situações onde as forças de contração da resina composta não sejam controláveis ou previsíveis. 


\section{CONCLUSÕES}




\section{CONCLUSÕES}

- A resina composta quimicamente ativada apresentou menores forças de contração de polimerização quando comparada com as resinas compostas fotoativadas de micropartículas, microhíbrida e de alta densidade.

- Entre as resinas fotoativadas, a de micropartículas apresentou os maiores valores de forças de contração de polimerização, enquanto a microhíbrida apresentou os menores valores.

- A densidade de potência apresentou-se como o fator mais importante em promover maiores valores de forças de contração de polimerização, quando comparado com o tipo de fonte de luz.

- O cimento de ionômero de vidro modificado por resina apresentou os menores valores de força de contração de polimerização, enquanto a resina de baixa viscosidade os maiores valores.

- O uso de base de cimento de ionômero de vidro modificado por resina promoveu menores valores de forças de contração, enquanto a base de resina de baixa viscosidade promoveu o aumento das forças de contração do sistema restaurador. 
- O aumento da espessura da base teve um efeito positivo para o cimento de ionômero de vidro modificado por resina, enquanto para a resina de baixa viscosidade não foi observado um efeito significativo. 
Anexo 
Anexo 1 - Forças máximas e curvas Força X Tempo obtidas para a resina Concise (3M).

\section{Corpo de Prova}

1

2

3

4

5

6

7

8

9

10

n

Média

Coeficiente de variação

Desvio padrão
Força Máxima (N)

4,02

4,29

4,60

4,25

3,71

4,51

3,76

4,78

3,96

4,28

10

4,216

8,386

0,3536

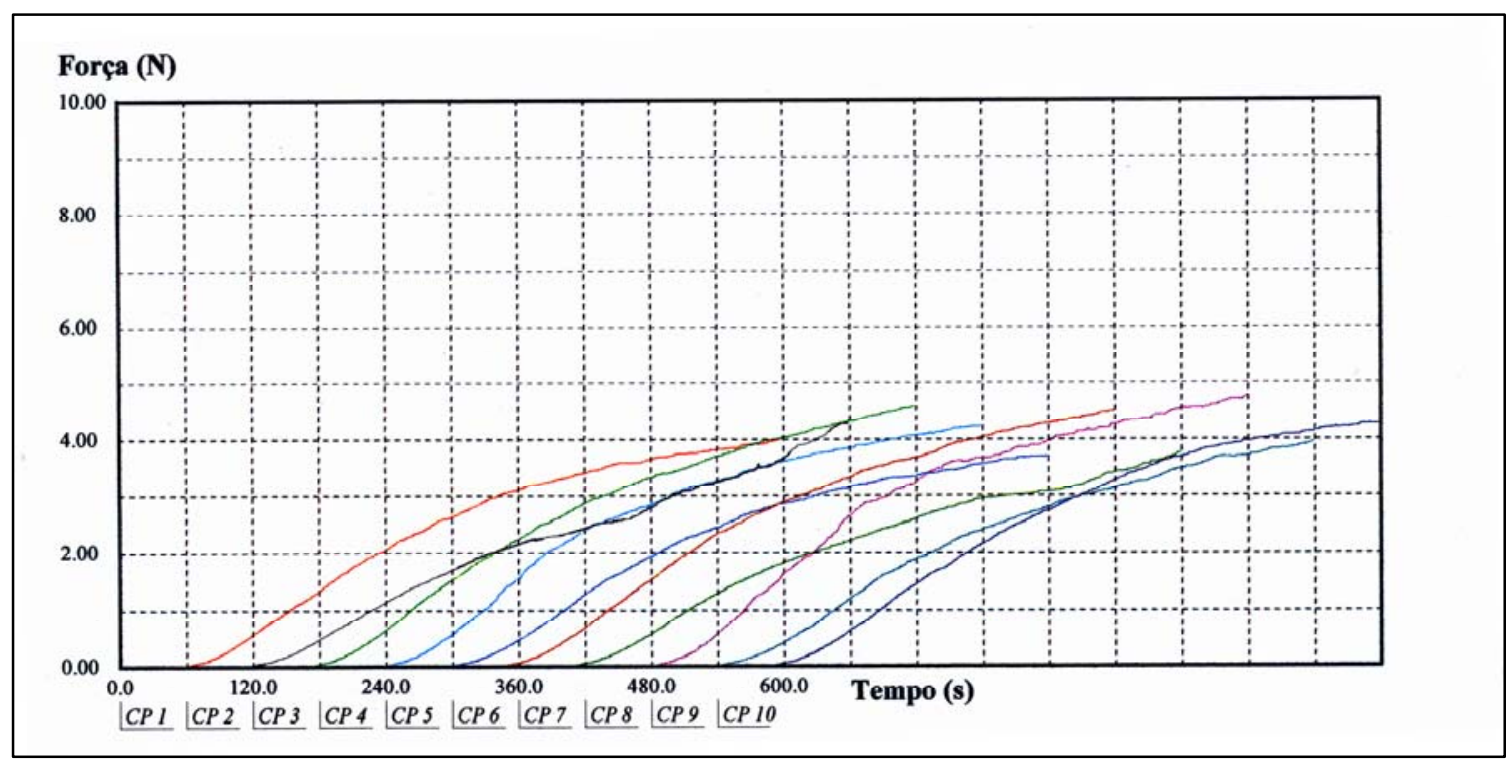

Curva força-tempo do comportamento mostrado por cada um dos corpos de prova realizados com Concise. 
Anexo 2 - Forças máximas e curvas Força $X$ Tempo obtidas para a resina Filtek A-110 (3M).

Corpo de Prova

1

2

3

4

5

6

7

8

9

10

n

Média

Coeficiente de variação

Desvio padrão
Força Máxima (N)

8,72

8,18

7,33

7,58

7,90

9,00

8,81

9,00

8,47

8,68

10

8,365

7,120

0,5956

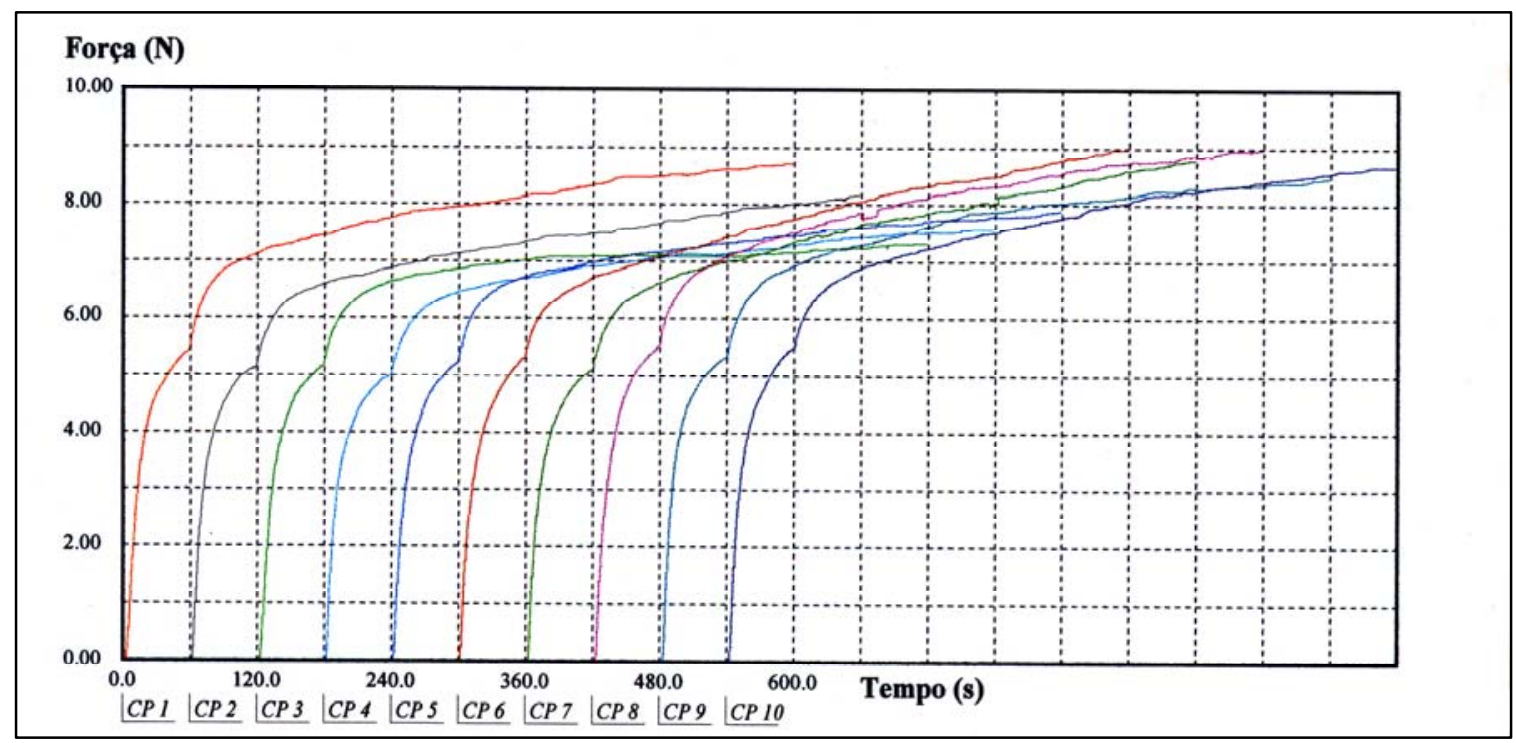

Curva força-tempo do comportamento mostrado por cada um dos corpos de prova realizados com Filtek A-110. 
Anexo 3 - Forças máximas e curvas Força X Tempo obtidas para a resina Filtek Z-250 (3M).

Corpo de Prova

1

2

3

4

5

6

7

8

9

10

n

Média

Coeficiente de variação

Desvio padrão
Força Máxima (N)

8,71

8,02

6,94

7,16

7,49

7,87

6,79

7,81

7,43

6,78

10

7,500

8,199

0,6149

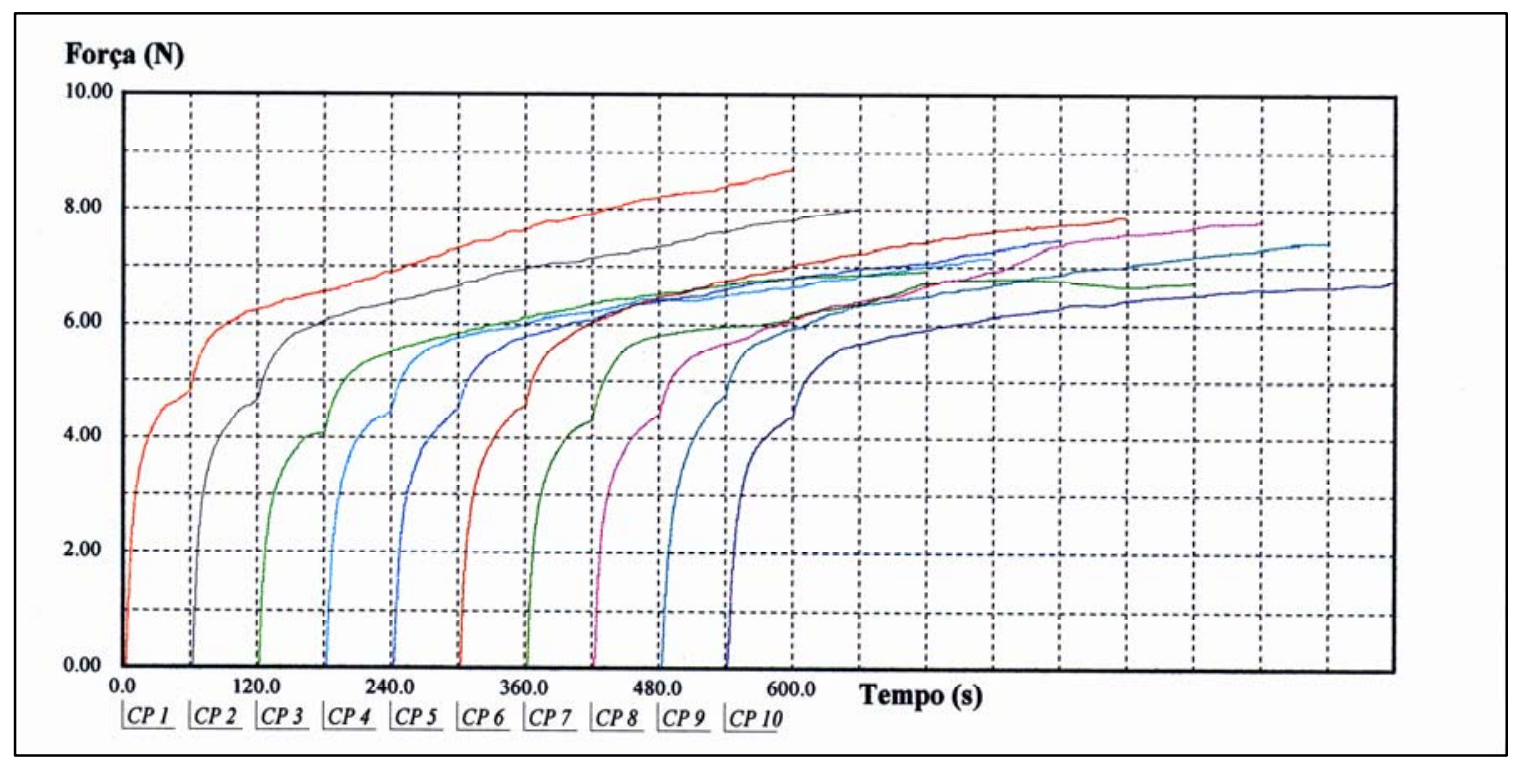

Curva força-tempo do comportamento mostrado por cada um dos corpos de prova realizados com Filtek Z-250. 
Anexo 4 - Forças máximas e curvas Força X Tempo obtidas para a resina Filtek P-60 (3M).

Corpo de Prova

1

2

3

4

5

6

7

8

9

10

$\mathrm{n}$

Média

Coeficiente de variação

Desvio padrão
Força Máxima (N)

8,60

8,79

8,05

8,69

9,13

7,78

6,91

8,03

7,59

7,53

10

8,111

8,467

0,6868

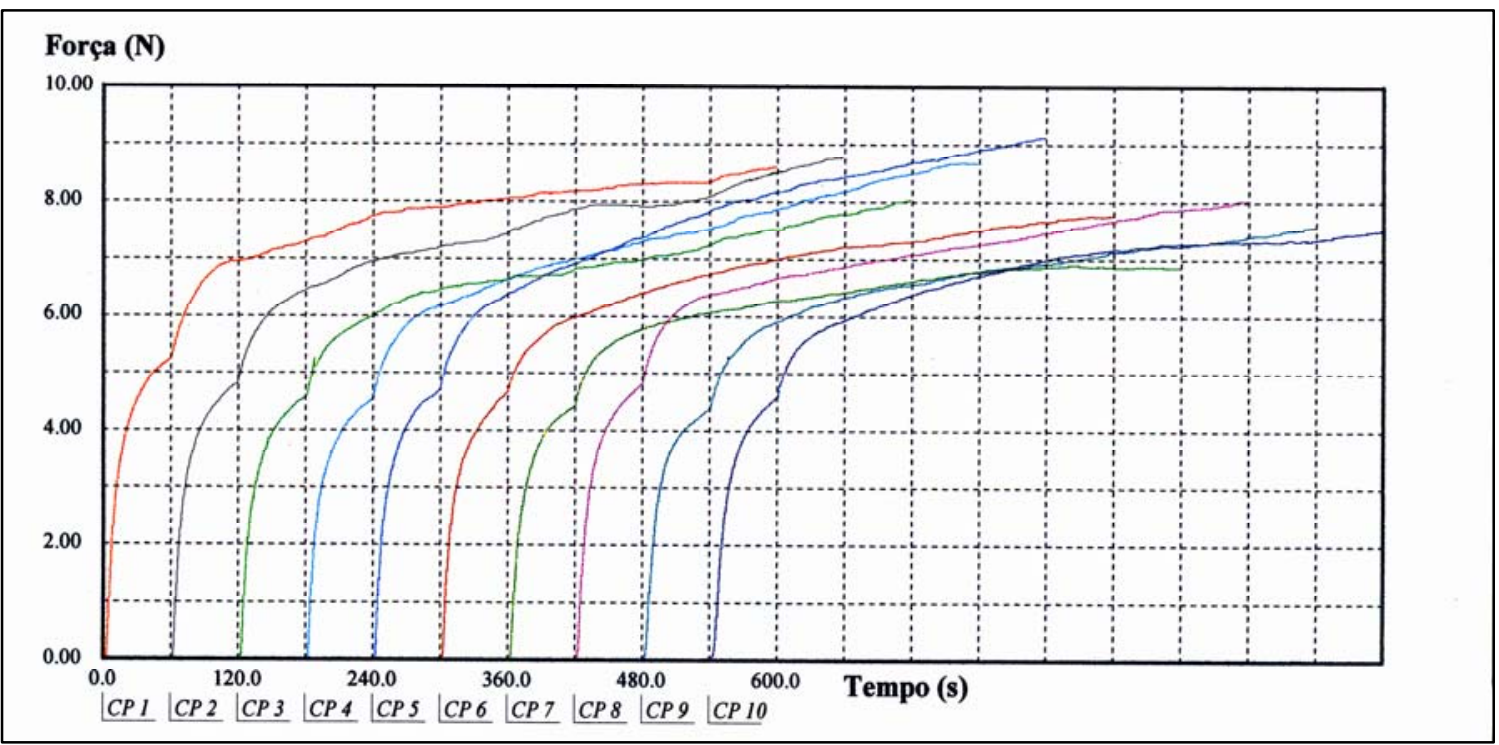

Curva força-tempo do comportamento mostrado por cada um dos corpos de prova realizados com Filtek P-60. 
Anexo 5 - Forças máximas e curvas Força X Tempo obtidas para a resina Z-250 (3M) polimerizada com fonte de luz Spectrum (Dentsply).

\section{Corpo de Prova}

1

2

3

4

5

6

7

8

9

10

$\mathrm{n}$

Média

Coeficiente de variação

Desvio padrão

\section{Força Máxima (N)}

6,42

6,30

6,22

6,50

6,18

6,22

5,95

6,13

6,59

6,64

10

6,316

3,444

0,2175

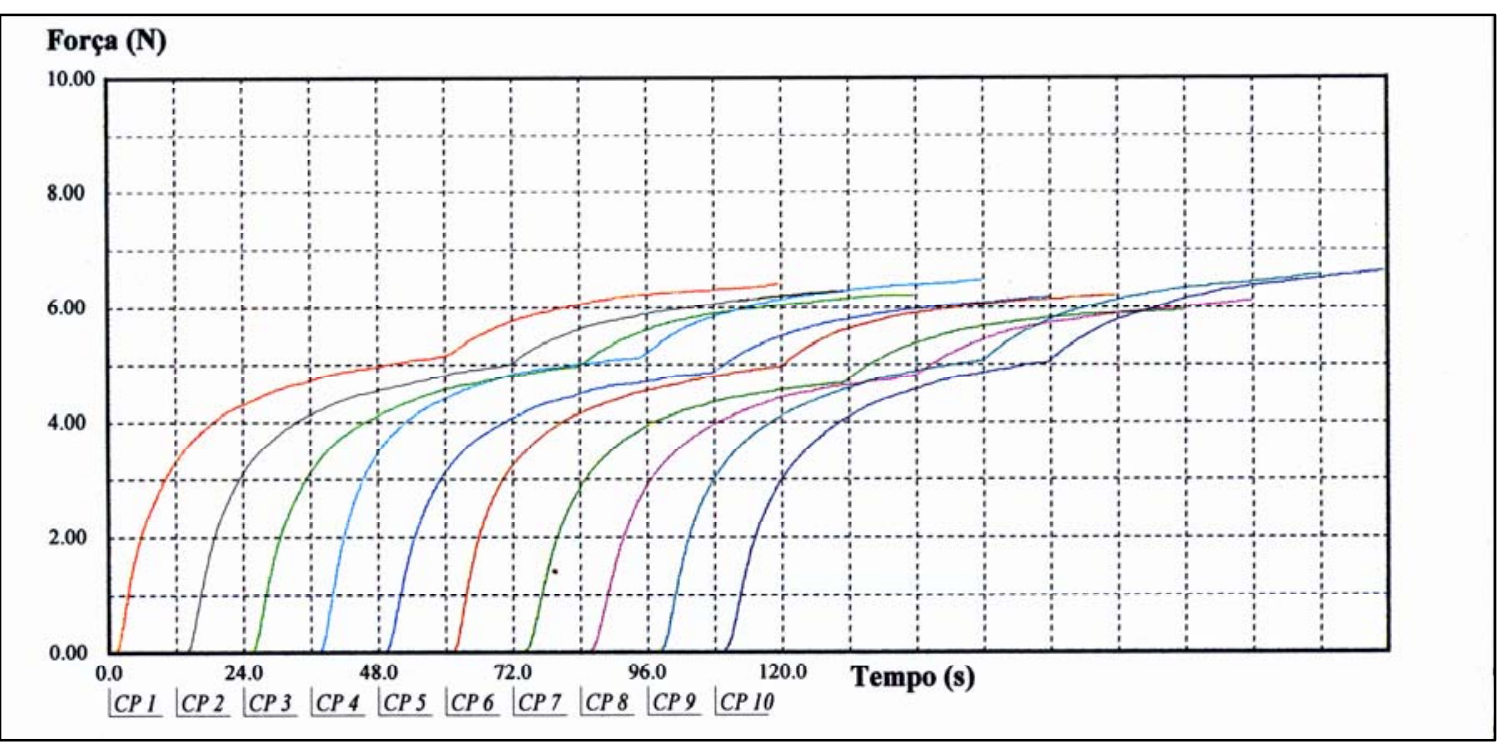

Curva força-tempo do comportamento mostrado por cada um dos corpos de prova de Filtek Z-250 polimerizados com fonte de luz Spectrum. 
Anexo 6 - Forças máximas e curvas Força X Tempo obtidas para a resina Z-250 (3M) polimerizada com fonte de luz Ultraled (Dabi Atlante).

\section{Corpo de Prova}

1

2

3

4

5

6

7

8

9

10

$\mathrm{n}$

Média

Coeficiente de variação

Desvio padrão

\section{Força Máxima (N)}

4,93

5,29

5,91

5,43

5,12

5,42

4,89

4,73

5,13

4,91

10

5,175

6,724

0,3480

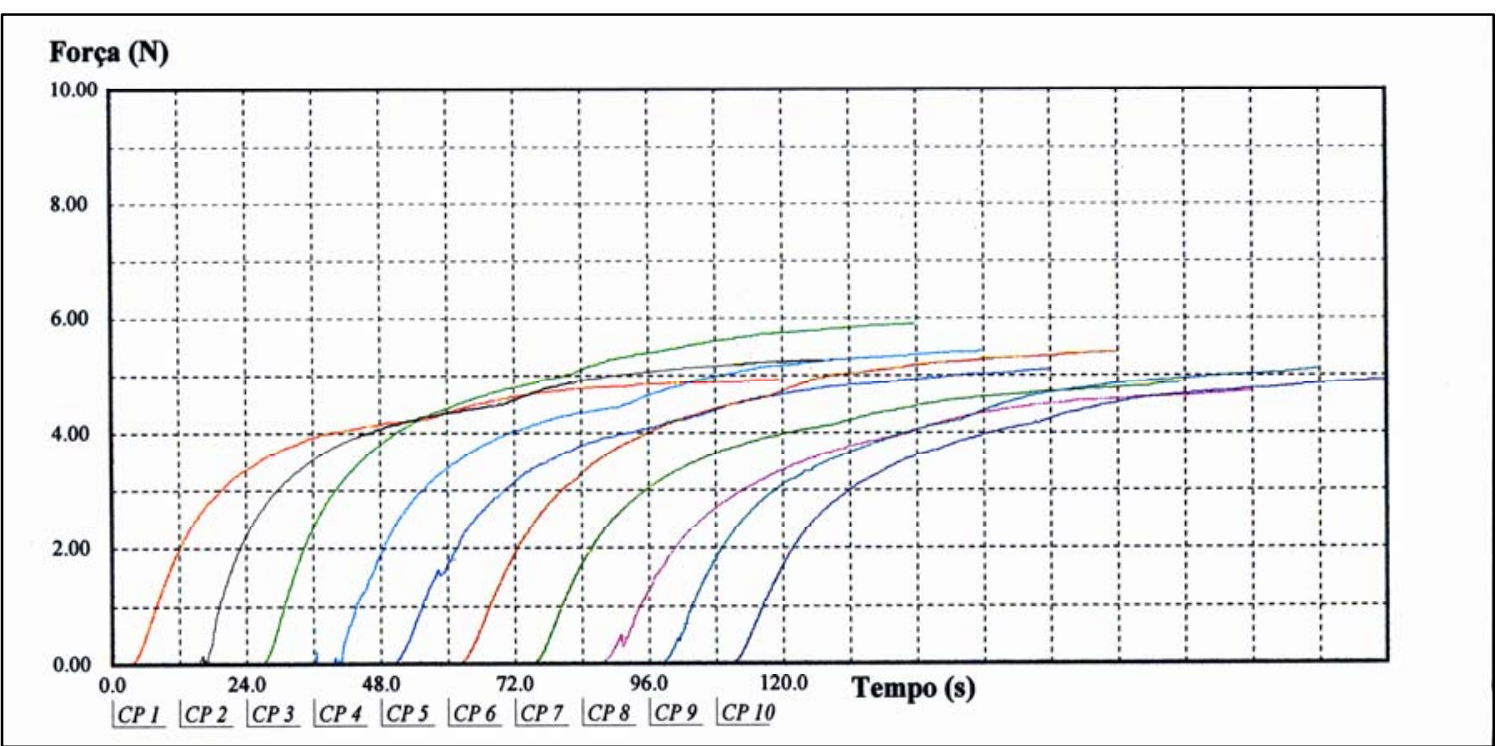

Curva força-tempo do comportamento mostrado por cada um dos corpos de prova de Filtek Z-250 polimerizados com fonte de luz Ultraled. 
Anexo 7 - Forças máximas e curvas Força X Tempo obtidas para a resina Z-250 (3M) polimerizada com fonte de luz Ultrablue IS $300 \mathrm{~mW} / \mathrm{cm}^{2}$ (DMC).

\section{Corpo de Prova}

1

2

3

4

5

6

7

8

9

10

n

Média

Coeficiente de variação

Desvio padrão

\section{Força Máxima (N)}

6,19

5,67

6,42

5,83

6,00

6,10

6,09

6,31

6,17

6,29

10

6,108

3,687

0,2252

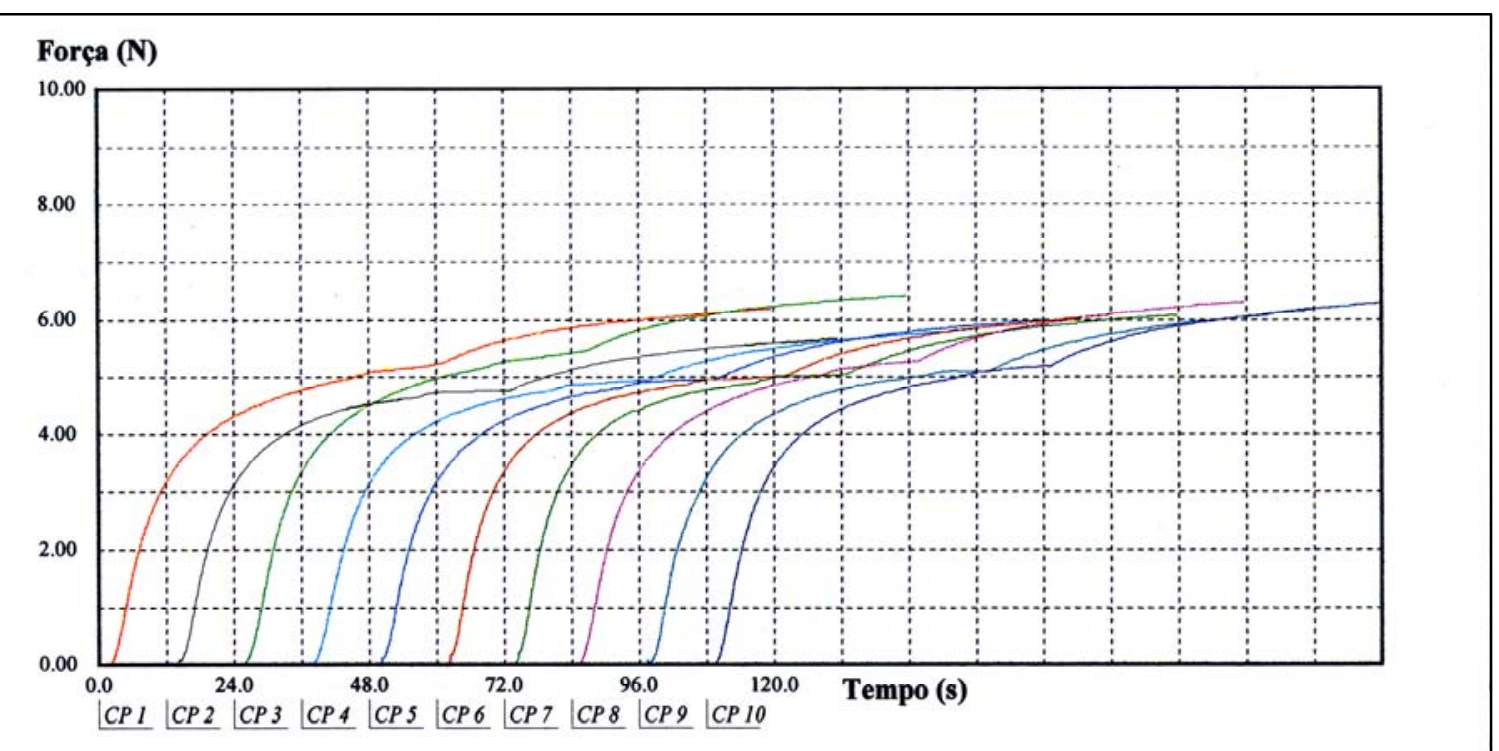

Curva força-tempo do comportamento mostrado por cada um dos corpos de prova de Filtek Z-250 polimerizados com fonte de luz Ultrablue IS a $300 \mathrm{~mW} / \mathrm{cm}^{2}$. 
Anexo 8 - Forças máximas e curvas Força X Tempo obtidas para a resina Z-250 (3M) polimerizada com fonte de luz Ultrablue IS $600 \mathrm{~mW} / \mathrm{cm}^{2}$ (DMC).

\section{Corpo de Prova}

1

2

3

4

5

6

7

8

9

10

$\mathrm{n}$

Média

Coeficiente de variação

Desvio padrão

\section{Força Máxima (N)}

6,03

6,62

6,79

6,63

6,85

6,37

6,54

6,51

6,46

6,17

10

6,497

3,948

0,2565

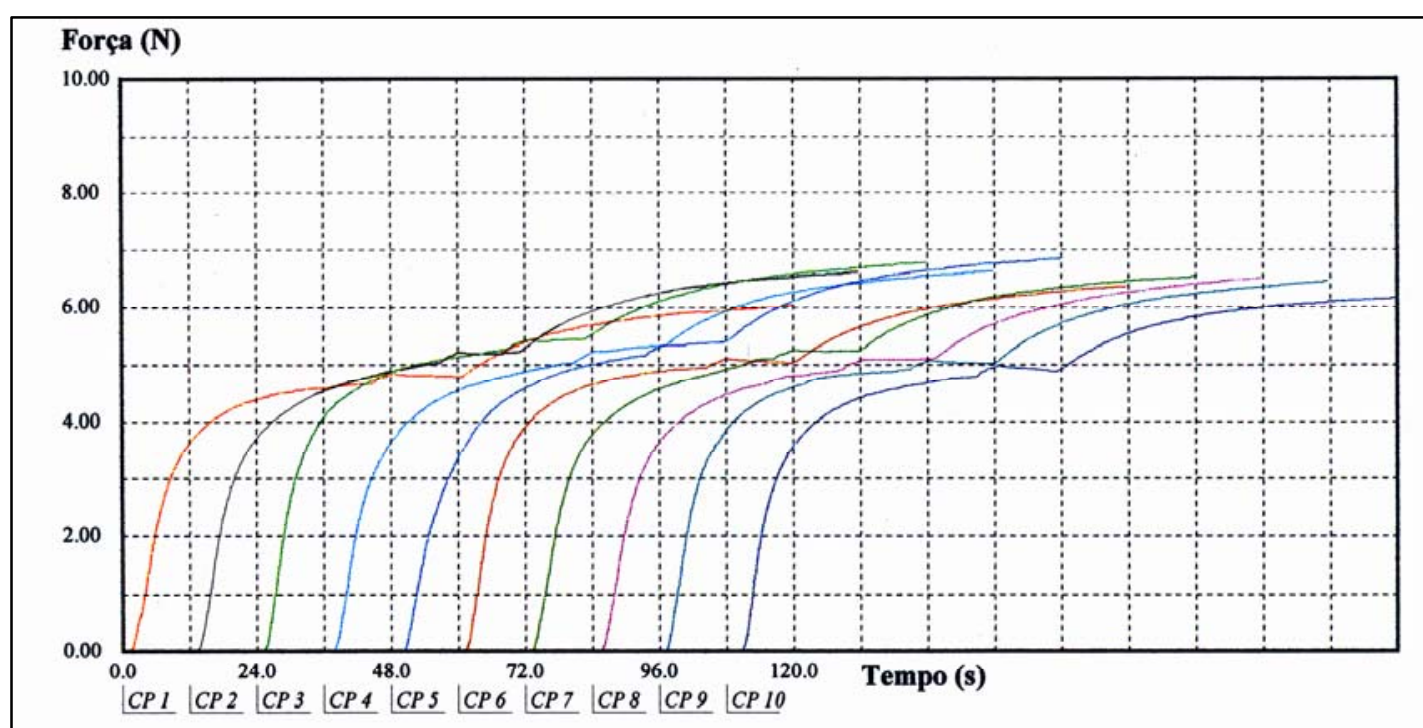

Curva força-tempo do comportamento mostrado por cada um dos corpos de prova de Filtek Z-250 polimerizados com fonte de luz Ultrablue IS a $600 \mathrm{~mW} / \mathrm{cm}^{2}$. 
Anexo 9 - Forças máximas e curvas Força X Tempo obtidas para a resina Filtek Z-250 (3M).

\section{Corpo de Prova}

1

2

3

4

5

6

7

8

9

10

$\mathrm{n}$

Média

Coeficiente de variação

Desvio padrão
Força Máxima (N)

6,85

6,42

6,32

6,36

6,01

6,09

6,47

6,06

6,11

6,53

10

6,321

4,141

0,2618

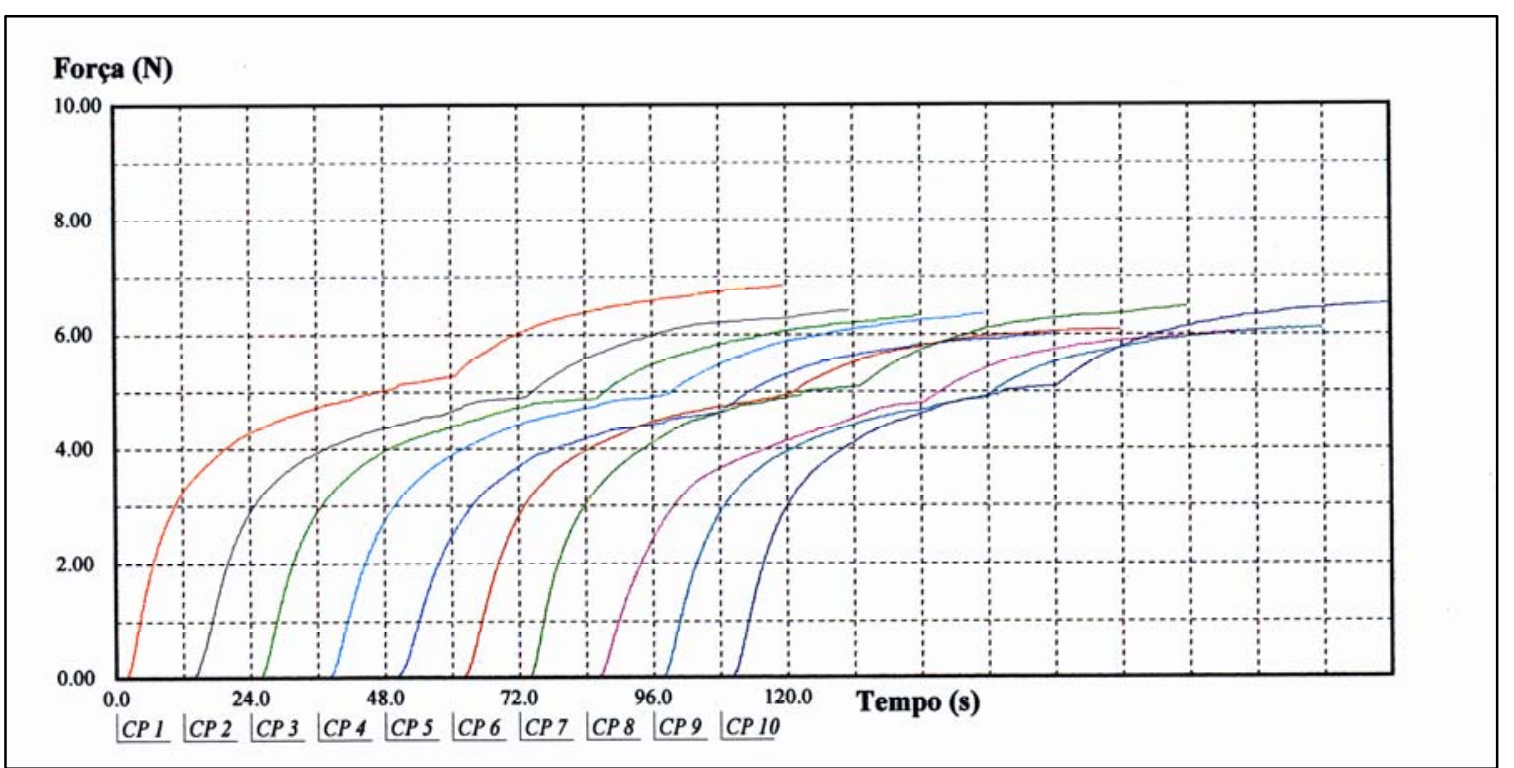

Curva força-tempo do comportamento mostrado por cada um dos corpos de prova realizados com Filtek Z-250. 
Anexo 10 - Forças máximas e curvas Força X Tempo obtidas para a Filtek Flow (3M).

\section{Corpo de Prova}

1

2

3

4

5

6

7

8

9

10

$\mathrm{n}$

Média

Coeficiente de variação

Desvio padrão

\section{Força Máxima (N)}

10,34

9,32

9,47

10,10

9,95

9,91

10,06

9,72

9,85

9,91

10

9,863

3,019

0,2977

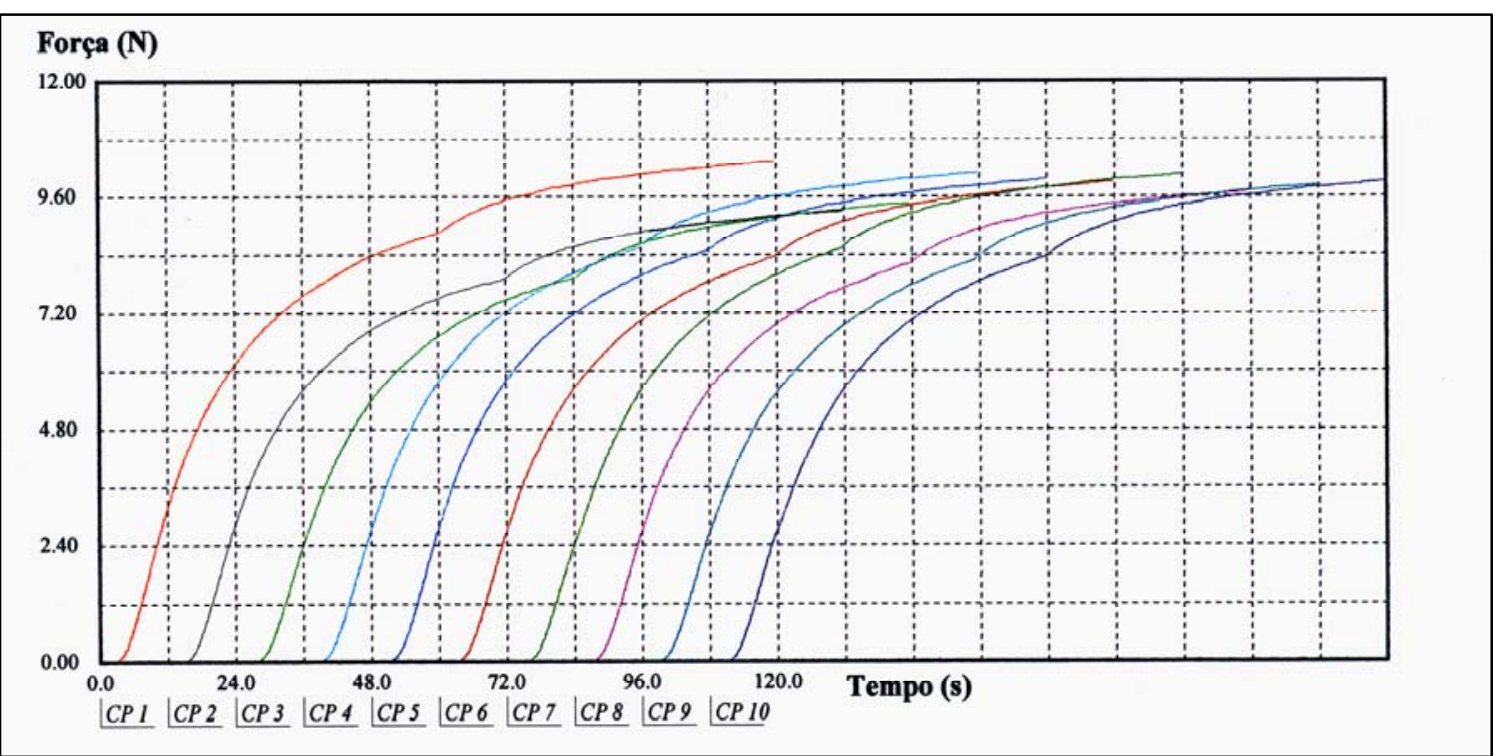

Curva força-tempo do comportamento mostrado por cada um dos corpos de prova realizados com Filtek Flow. 
Anexo 11 - Forças máximas e curvas Força X Tempo obtidas para Vitrebond (3M).

\section{Corpo de Prova}

1

2

3

4

5

6

7

8

9

10

n

Média

Coeficiente de variação

Desvio padrão
Força Máxima (N)

1,82

1,68

1,95

1,96

2,03

2,01

1,38

1,99

2,20

1,74

10

1,876

12,31

0,2308

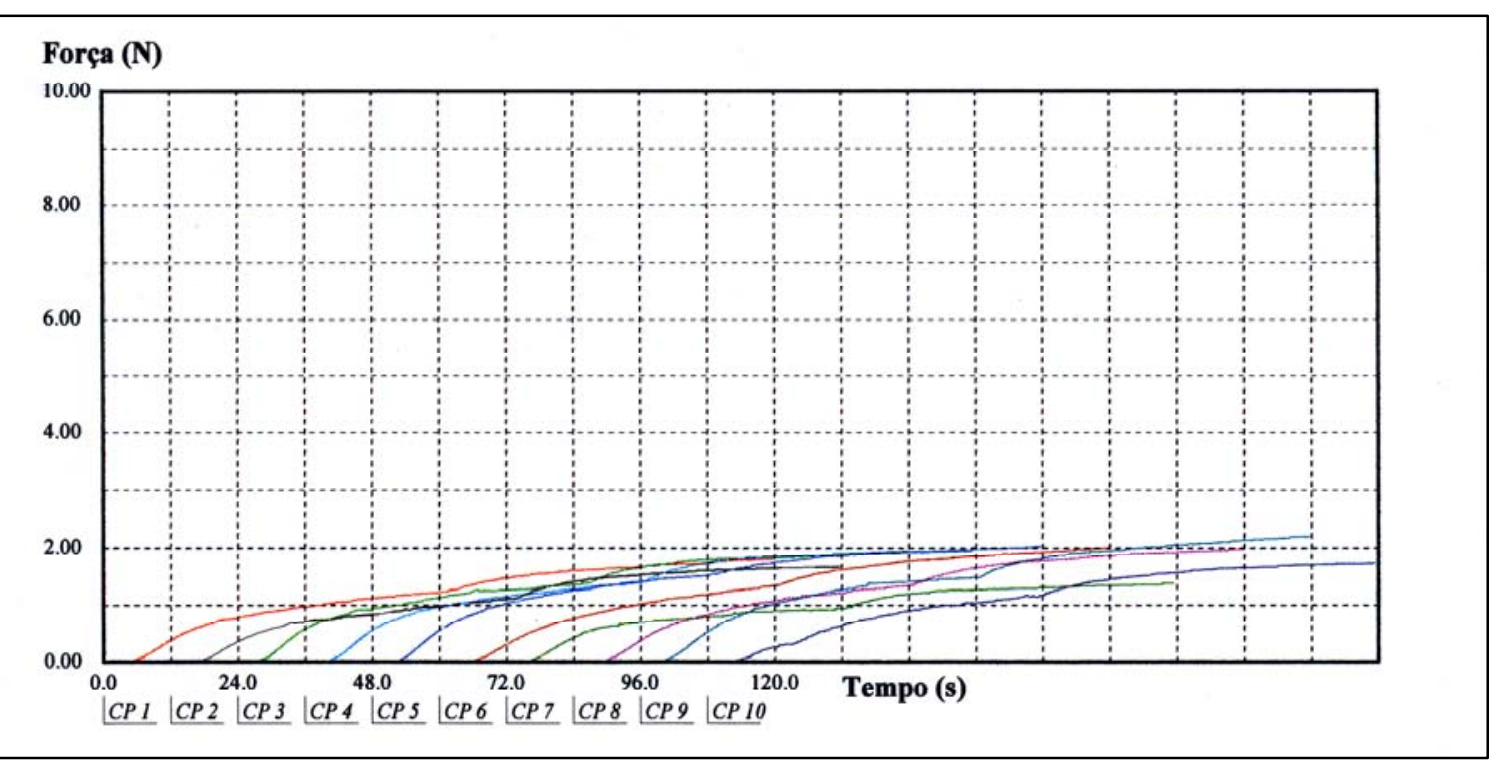

Curva força-tempo do comportamento mostrado por cada um dos corpos de prova realizados com Vitrebond 
Anexo 12 - Forças máximas e curvas Força $X$ Tempo obtidas para a resina Filtek Z-250 com camada de 0,5mm de Filtek Flow (3M) como material intermediário.

\section{Corpo de Prova}

1

2

3

4

5

6

7

8

9

10

n

Média

Coeficiente de variação

Desvio padrão

\section{Força Máxima (N)}

7,41

6,98

7,02

6,88

6,78

6,67

6,58

6,79

6,66

6,90

10

6,868

3,481

0,2391

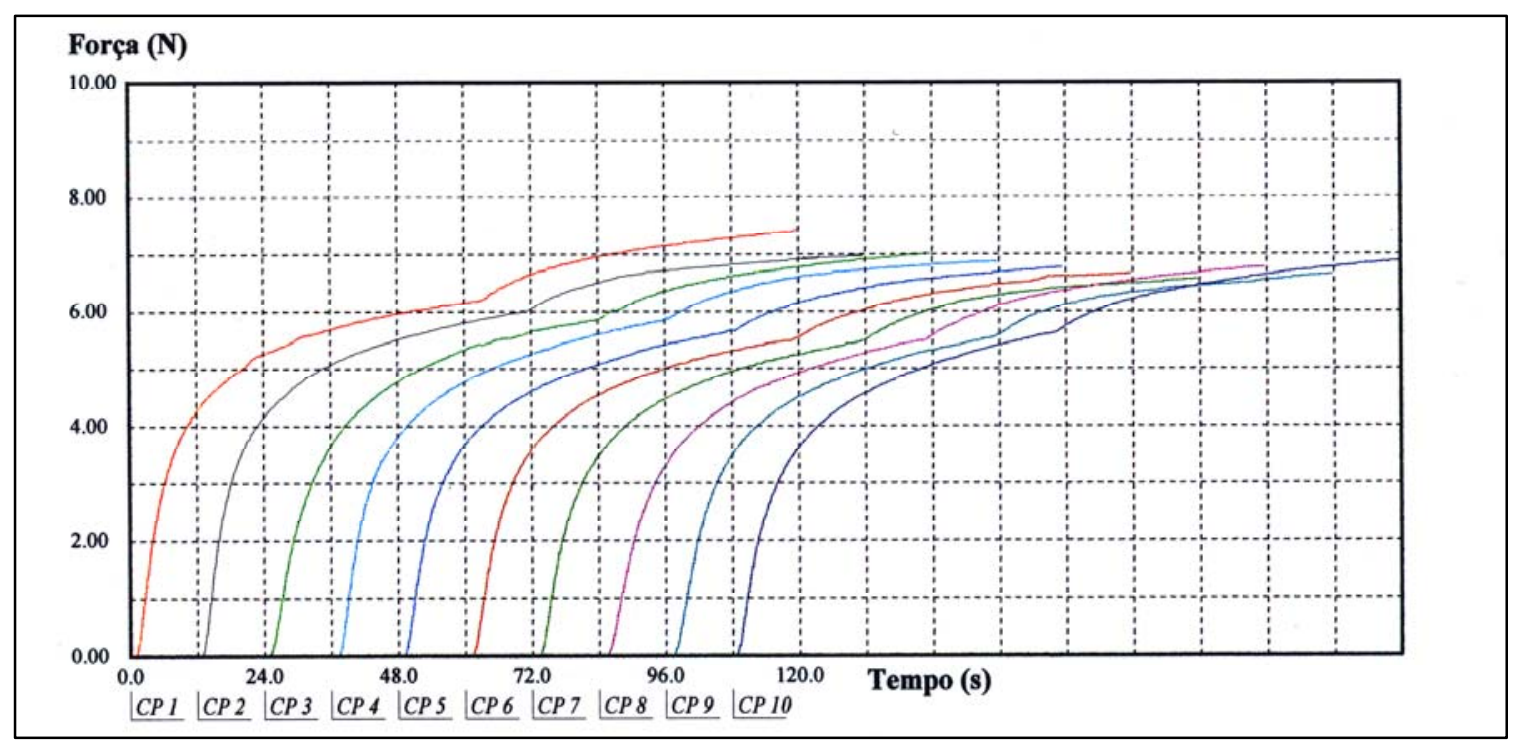

Curva força-tempo do comportamento mostrado por cada um dos corpos de prova de Filtek Z-250 com camada de 0,5mm de Filtek Flow como material intermediário. 
Anexo 13 - Forças máximas e curvas Força X Tempo obtidas para a resina Filtek Z-250 com camada de $1 \mathrm{~mm}$ de Filtek Flow (3M) como material intermediário.

Corpo de Prova

1

2

3

4

5

6

7

8

9

10

$\mathrm{n}$

Média

Coeficiente de variação

Desvio padrão
Força Máxima (N)

6,56

6,68

7,00

7,08

7,47

6,32

7,43

6,97

7,24

7,02

10

6,978

5,280

0,3684

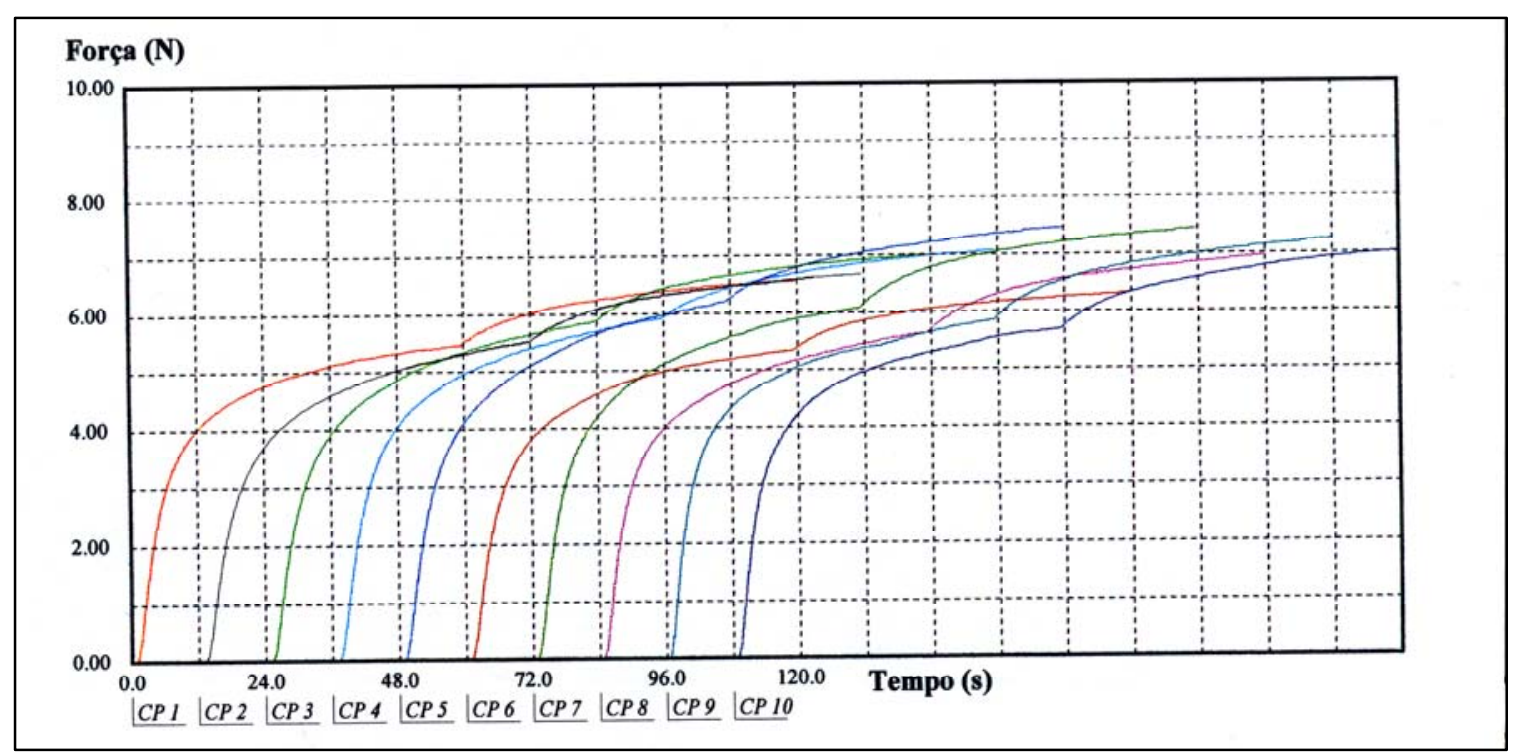

Curva força-tempo do comportamento mostrado por cada um dos corpos de prova de Filtek Z-250 com camada de 1mm de Filtek Flow como material intermediário. 
Anexo 14 - Forças máximas e curvas Força X Tempo obtidas para a resina Filtek Z-250 com camada de $0,5 \mathrm{~mm}$ de Vitrebond (3M) como material intermediário.

Corpo de Prova

1

2

3

4

5

6

7

8

9

10

$\mathrm{n}$

Média

Coeficiente de variação

Desvio padrão
Força Máxima (N)

3,89

4,39

4,86

4,28

3,71

4,22

4,25

4,35

3,09

3,71

10

4,075

11,97

0,4880

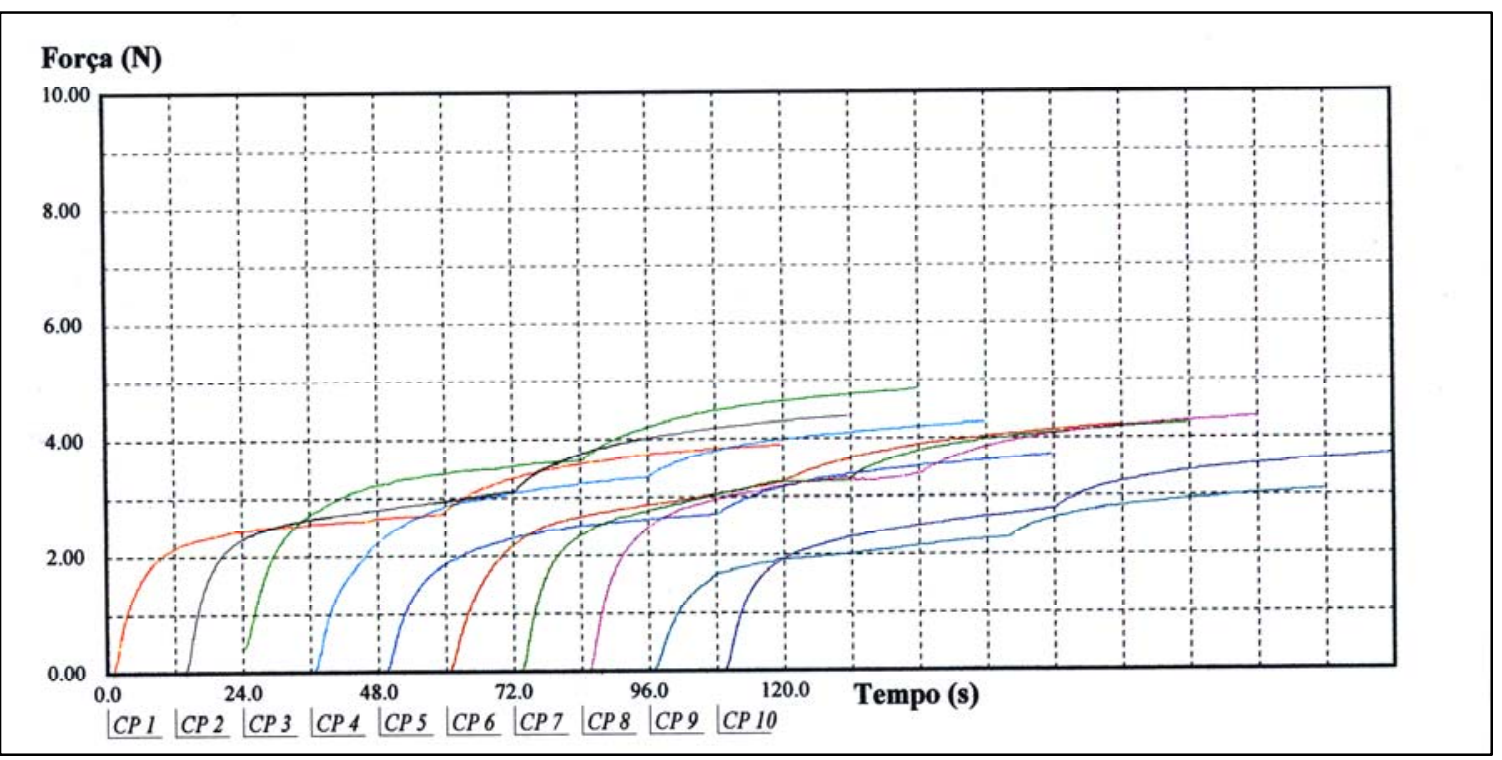

Curva força-tempo do comportamento mostrado por cada um dos corpos de prova de Filtek Z-250 com camada de 0,5mm de Vitrebond como material intermediário. 
Anexo 15 - Forças máximas e curvas Força X Tempo obtidas para a resina Filtek Z-250 com camada de $1 \mathrm{~mm}$ de Vitrebond (3M) como material intermediário.

Corpo de Prova

1

2

3

4

5

6

7

8

9

10

$\mathrm{n}$

Média

Coeficiente de variação

Desvio padrão
Força Máxima (N)

3,01

3,32

3,28

3,35

3,00

2,55

2,46

2,02

2,99

2,13

10

2,812

17,40

0,4894

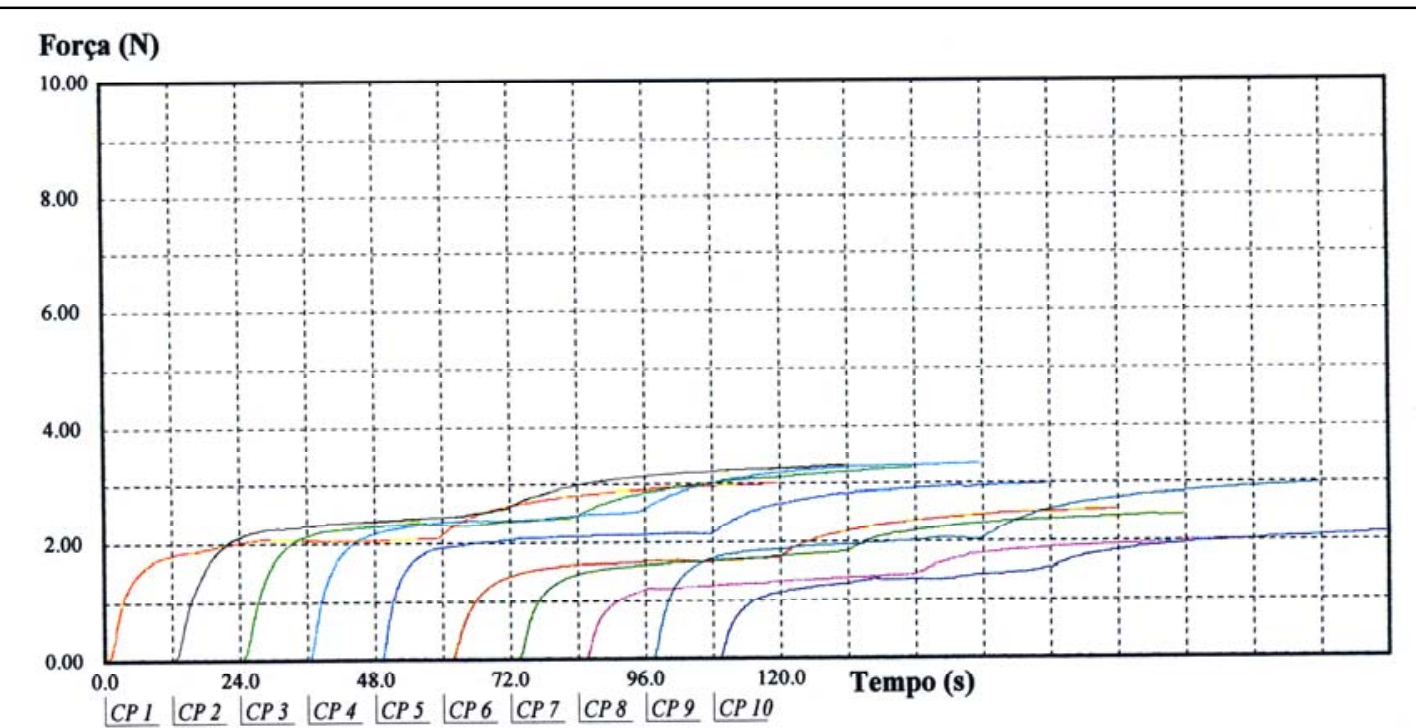

Curva força-tempo do comportamento mostrado por cada um dos corpos de prova de Filtek Z-250 com camada de $1 \mathrm{~mm}$ de Vitrebond como material intermediário. 


\section{REFERÊNCIAS BIBLIOGRÁFICAS}




\section{REFERÊNCIAS BIBLIOGRÁFICAS}

1. ALOMARI, Q.D.; REINHARDT, J.W.; BOYER, D.B. Effect of liners on cusp deflection and gap formation in composite restoration. Oper. Dent., v.26, p.406$11,2001$.

2. ALSTER, D. et al. Polymerization contraction stress in thin resin composite layers as a function of layer thickness. Dent. Mat., v.13, p.146-150, May 1997.

3. ASENJO-MARTINEZ M.A.J. et al. Avaliação da contração de polimerização de uma resina composta utilizando a técnica de rampa. In: REUNIÃO ANUAL DA SOCIEDADE BRASILEIRA DE PESQUISA ODONTOLÓGICA, 20., Águas de Lindóia, 2003. Anais. Águas de Lindóia, Ed. Científica, 2003. p.190.

4. AZEVEDO, J.F.D.G. et al. Avaliação da força de contração de polimerização utilizando a técnica do pulso tardio com fonte de luz VIP. In: REUNIÃO ANUAL DA SOCIEDADE BRASILEIRA DE PESQUISA ODONTOLÓGICA, 20., Águas de Lindóia, 2003. Anais. Águas de Lindóia, Ed. Científica, 2003. p.191.

5. BAUSCH, J.R. et al. Clinical significance of polymerization shrinkage of composite resins. J. Prosthet. Dent., v.48, n.1, p.59-67, July 1982.

6. BEZNOS, C. Microleakage at the cervical margin of composite class II cavities with different restorative techniques. Oper. Dent., v.26, p.60-69, 2001.

7. BOUSCHLICHER, M.R.; VARGAS, M.A.; BOYER, D.B. Effect of composite type, light intensity, configuration factor and laser polymerization on polymerization contraction forces. Amer. J. Dent., v.10, n.2, p.88-96, April 1997.

8. BOWEN, R.F. Adhesive bonding of various materials to hard tooth tissues VI. Forces developing in direct-filling materials during hardening. J. Amer. dent. Ass., v.74, p.439-44, Feb. 1967. 
9. BOWEN, R.L.; NEMOTO, K.; RASPON, J.E. Adhesive bonding of various materials to hard tooth tissues: forces developing in composite materials during hardening. J. Amer. dent. Ass., v.106, n.4, p.475-7, Apr. 1983.

10. BRAEM, M. et al. Stiffness increase during the setting of dentistry composite resins. J. dent. Res., v.66, n.12, p.1713-6, Dec. 1987.

11.BRAGA, R.P.; FERRACANE, J.L. Contraction stress related to degree of convertion and reaction kinetics. J. dent. Res., v.81, n.2, p.114-8, Feb. 2002.

12. CARVALHO, R.M. et al. A review of polymerization contraction: the influence of stress development versus stress relief. Oper. Dent., v. 21, p.17-24, Jan.Feb.1996.

13.CASTAÑEDA-ESPINOSA J.C. Avaliaçaõ da microinfiltração em restaurações mistas de classe $V$. Influência da contração de polimerização, do desenho cavitário. Bauru, 1991. p. Dissertação (Mestrado) - Faculdade de Odontologia de Bauru, Universidade de São Paulo.

14.CASTAÑEDA-ESPINOSA, J.C.; MONDELLI, R.F.L. Avaliação das forças de contração na polimerização de resinas compostas ativadas com luz halógena e LED. In: REUNIÃO ANUAL DA SOCIEDADE BRASILEIRA DE PESQUISA ODONTOLÓGICA, 19., Águas de Lindóia, 2002. Anais. Águas de Lindóia, Ed. Científica, 2002. p.15.

15. CAVALCANTI, A.P.; CASTAÑEDA-ESPINOSA, J.C.; MONDELLI, R.F.L. Avaliação das forças de contração de polimerização em diferentes técnicas com a mesma energia de irradiação. In: REUNIÃO ANUAL DA SOCIEDADE BRASILEIRA DE PESQUISA ODONTOLÓGICA, 20., Águas de Lindóia, 2003. Anais. Águas de Lindóia, Ed. Científica, 2003. p.95.

16. CAVINA, D.A. Avaliação das forças geradas durante a contração de polimerização de resinas compostas híbridas. Bauru, 2003. 118p. Dissertação (Mestrado). Faculdade de Odontologia de Bauru, Universidade de São Paulo.

17. CAVINA, D.A. et al. Análise das forças geradas durante a contração de polimerização de resinas compostas ativadas utilizando LED com diferentes 
tempos. In: REUNIÃO ANUAL DA SOCIEDADE BRASILEIRA DE PESQUISA ODONTOLÓGICA, 20., Águas de Lindóia, 2003. Anais. Águas de Lindóia, Ed. Científica, 2003. p.184.

18. CHEN, H.Y. et al. Polymerization contraction stress in light cured packable composite resins. Dent. Mater., v.17, n.3, p.253-9, Mar. 2001.

19. $\mathrm{CHO}$, B.H. et al. Effect of interfacial bond quality on the direction of polymerization shrinkage flow in resin composite restorations. Oper. Dent.., v.27, n.3, p.297-304, Mai-Jun. 2002.

20. CHOI, K.K.; CONDON, J.R. The effects of adhesive thickness on polymerization contraction stress of composite. J. dent. Res., v.79, n.3, p.8127, Mar. 2000.

21. COELHO SANTOS, M.J.M. et al. Effect of light curing method on volumetric polymerization shrinkage of resin composites. Oper. Dent., v.29, n.2, p.157-61, Feb. 2004.

22. CONDON, J.R.; FERRACANE, J.L. Reduction of composite contraction stress through non-bonded microfiller particle. Dent. Mat., v.14, n.6, p.256-260, July 1998.

23.CONDON, J.R.; FERRACANE, J.L. Assesing the effect of composite formulation on polymerization stress. J. Amer. dent. Ass., v.131, n.4, p.33541, Apr. 2000.

24. DAUVILLIER, B.S et al. Visco-elastic parameters of dental restorative materials dring setting. J. dent. Res., v.79, n.3, p.818-23, Mar. 2000.

25.DAVIDSON, C.L. Resisting the curing contraction with adhesive composites. J. Prosthet. Dent., v.55, n.4, p.446-7, April 1986.

26.DAVIDSON, C.L. Activation energy, light sorces and depth of cure. In: SIMPOSIO INTERNAZIONALE DE ODONTOIARIA ADESIVA E 
RICONSTRUTIVA, 4., S. Margherita Ligure, 2000. Atti. Italy, Probagonsti in Odontoiatria, 2000. p.68-72.

27.DAVIDSON, C.L. Glass-ionomer: a smart material? In: BERTELLI, E.; FERRARI, M. CLINICAL ALTERNATIVES IN RESTORARIVE DENTISTRY. Certosa di Pontignano, Italy, 2001. Università degli Studi di Siena, 2001. P.1122.

28.DAVIDSON C.L. New Developments in restorative materials photopolymerization. In: BERTELLI, E.; FERRARI, M. CLINICAL ALTERNATIVES IN RESTORARIVE DENTISTRY. Certosa di Pontignano, Italy, 2001. Università degli Studi di Siena, 2001. p. 59-64.

29.DAVIDSON, C.L; DE GEE, A.J. Relaxation of polymerization contraction stresses by flow in dental composites. J. dent. Res., v.63, n.2, p.246-8, Feb. 1984.

30.DAVIDSON, C.L.; DE GEE, A.J. Light curing units, polymerization and clinical implictions. J. adhes. Dent., v.2, n.3, p.167-173, 2000.

31.DAVIDSON, C.L.; DE GEE, A.J.; FEILZER, A.J. The competition between the composite-dentin bond strength and the polymerization contraction stress. $\mathbf{J}$. dent. Res., v.63, n.12, p.1396-9, Dec. 1984.

32. DAVIDSON, C.L.; FEILZER, A.J. Polymerization shrinkage and polymerization shrinkage stress in polymer-based restoratives. J. Dent., v.25, n.6, p.435-440, Nov. 1997.

33. DIETRICH, Th et al. Marginal adaptation of direct composite and sandwich restorations in class II cavities with cervical margins in dentine. J. Dent., v.27, n.2, p.119-28, Mar. 1999.

34.FEILZER, A.J.; de GEE, A.J.; DAVIDSON, C.L. Setting stress in composite resin in relation to configuration of the restoration. J. dent. Res., v.66, n.11, p.1636-9, Nov. 1987. 
35. FEILZER, A.J., DE GEE, A.J., DAVIDSON, C.L. Relaxation of polimerization contraction shear stress by hygroscopic expansion. J. dent. Res., v.69, n.1, p.36-9, Jan. 1990.

36. FEILZER, A.J., DE GEE, A.J., DAVIDSON, C.L. Quantitative determination of stress reduction by flow in composite restorations. Dent. Mater., v.6, n.6, p.167-71, July 1990.

37. FEILZER, A.J., DE GEE, A.J., DAVIDSON, C.L. Setting stresses in composites for two dfferent curing modes. Dent. Mater., v.9, n.1, p.2-5, Jan. 1993.

38. FRANCO, E.B; LOPES, L.G. Conceitos atuais na polimerização de sistemas restauradores resinosos. Biodonto, v.1, n.2, p.10-59, Março-Abril 2003.

39. GORACCI, G. The effects of gradually actived polymerization on cavity bonding. In: SIMPOSIO ITERNAZIONALE DE ODONTOIARIA ADESIVA E RICONSTRUTIVA, 4., S. Margherita Ligure, 2000. Atti. Italy, Probagonsti in Odontoiatria, 2000. p.35-9.

40. HAGGE, M. et al. Effect of four intermediate layer treatments on microleakage of class II composite restorations. Gen. Dent., p.489-494, Sept.- Oct. 2001.

41. HANSEN, E.K.; ASMUSSEN, E. Marginal adaptation of posterior resins: Effect of dentin-bonding agent and hygroscopic expansion. Dent. Mater., v.5, n.2, p.122-6, Mar. 1989.

42. HEGHDAHL, T.; GJERDET, N.R. Contraction stresses of composite resin filling materials. Acta Odont. Scan. , v.35, n.4, p.191-5, 1977.

43.KEMP-SCHOLTE, C.M.; DAVIDSON, C.L. Marginal sealing of curing contraction gaps in class $\mathrm{V}$ composite resin restorations. J. dent. Res., v. $67 \mathrm{n}$. 5, p.841-5, May 1988.

44.KEMP-SCHOLTE, C.M.; DAVIDSON, C.L. Complete marginal seal of class V resin composite restorations effected by increased flexibility. J. dent. Res., v.69, n.6, p.1240-3, June 1990. 
45. KEMP-SCHOLTE, C.M.; DAVIDSON, C.L. Marginal integrity related to bond strength and strain capacity of composite resin restorative systems. $\mathbf{J}$. Prosthet. Dent., v.64, n.6, p.658-64, Dec. 1990.

46. KINOMOTO, Y. et al. Comparison of polymerization contraction stresses between self and light curing composites. J. Dent., v.27, n.5, p.383-9, July 1999.

47. KORAN, P.; KÜRSCHNER, R. Effect of sequential versus continuous irradiation of light-cure resin composite on shrinkage, viscosity, adhesion, and degree of polymerization. Amer. J. Dent., v.11, n.1, p.17-22, Feb. 1998.

48. KREJCI, I.; LUTZ, F.; KREJCI, D. The influence of different base materials on marginal adaptation and wear of conventional class II composite resin restorations. Quintessence Int., v.19, n.3, p.191-8, Mar. 1988.

49. KURACHI, C. et al. Hardness evaluation of a dental composite polymerized with experimental LED-based devices. Dent. Mater., v.17, n.4, p.309-15, Jul. 2001.

50. LABELLA, R. et al. Polimerization shrinkage and elasticty of flowable composite and filled adhesives. Dent. Mater., v.15, n.2, p.128-37, Mar. 1999.

51. LEONARD, D.L. et.al. Polymerization efficiency of LED curing lights. J. Esthet. Restor. Dent., v.14, n.5,p.286-95, 2002.

52. LÖESCHE, G.M. Marginal adaptation of class II composite fillings: guided polymerization vs. reduced light intensity. J. adhes. Dent, v.1, n.1, p.31-39, 1999.

53. LOPES, L.G. Avaliação da contração de polimerização e as tensões promovidas em função de diferentes sistemas de polimerização e de materiais restauradores estéticos. Bauru, 2004. 134p. Tese (Doutorado). Faculdade de Odontologia de Bauru, Universidade de São Paulo. 
54. MALMSTRÖM, H. et al. E. Effect of thickness of flowable resins on marginal leakage in class II composite restorations. Oper. Dent., v.27, n.4, p.373-80, July/Aug. 2002.

55. MEREDITH, N.; SETCHELL, D.J. In vitro measurement of cuspal strain and displacement in composite restored teeth. J. Dent., v.25, n.3, p.331-7, 1997.

56. MIGUEL, A.; DE LA MACORRA, J.C. A predicitive formula of the contraction stress in restorative and luting materials attending to free and adhered surfaces, volume and deformation. Dent. Mater., v.17, n.3, p.241-6, Mar. 2001.

57. MILLS, R.W.; JANDT, K.D.; ASHWORTH, S.H. Dental composite depth of cure with halogen and blue light emitting diode technology. Brit. dent. J., v.186, n.8, p.388-91, April 1999.

58. MITRA, S.B. Adhesion to dentin and physical properties of a light cured glass ionomer liner/base. J. dent. Res., v.70, n.1, p.72-4, Jan. 1991.

59. MONDELLI, R.F.L; CASTAÑEDA-ESPINOSA, J.C; FRANCO, E.B. Avaliação das forças de contração geradas na polimerização segundo o tipo de resina composta e modo de ativação. In: REUNIÃO ANUAL DA SOCIEDADE BRASILEIRA DE PESQUISA ODONTOLÓGICA, 19., Águas de Lindóia, 2002. Anais. Águas de Lindóia, Ed. Científica, 2002. p.241.

60. NAGEL, R. Operation and diagnostic features of the VIP light. Comp. Continuing Educ. Dent., v.20, p.55-59, Nov. 1999.

61. PAYNE IV, J.H. The marginal seal of class II restorations: flowable composite resin compared to injectable glass ionomer. J. Clin. Ped. Dent., v.23, n.2, p.123-30, 1999.

62. PRATI, C. Early marginal microleakage in class II resin composite restorations. Dent.Mater., v.5, n.11, p.392-8, Nov. 1989.

63. PRATI, C. Early marginal leakage and shear bond strength of adhesive restorative systems. Dent. Mater., v.6, n.7, p.195-200, July 1990. 
64. RUEGGEBERG, F. Contemporary issues in photocuring. Comp. Continuing Educ. Dent., v.20, p.4-15, Nov. 1999.

65. RUEGGEBERG, F.; TAMARESELVY, K. Resin cure determination by polymerization shrinkage. Dent. Mater., v.11, p.265-8, July 1995.

66.SANTOS, M.J.C.M.; SILVA e SOUZA JR., M.H.; MONDELLI, R.F.L. Novos conceitos relacionados à fotopolimerização das resinas compostas. JBD, v. 1., n.1, Jan./Mar. 2002.

67.SAKAGUCHI, R.L.A review of the curing mechanics of composites and their significance in dental applications. Comp. Continuing Educ. Dent., v.20, p.16-23, Nov. 1999.

68. SAKAGUCHI, R.L. ; BERGE, H.X. Reduced light energ density decreases postgel contraction while maintaining degree of convertion in composites. J. Dent., v.26, p.695-700, 1998.

69.SAKAGUCHI, R.L. ; FERRACANE, J.L. Stress transfer from polymerization shrinkage of a chemical cured composite bonded to a pre-cast composite substrate. Dent. Mater., v.14, n.2, p.106-11, Mar. 1998.

70.SAKAGUCHI, R.L.; WILTBANK, B.D.; MURCHISON, C.F. Contraction force rate of polymer composites is linearly correlated with irradiance. Dent. Mater., v.20, p.402-7, 2004.

71.SUH, B.I. Controlling and understanding the polymerization shrinkage induced stresses in light-cured composites. Comp. Continuing Educ. Dent., v.20, p.34-41, Nov. 1999.

72. SUH, B.I. Understanding and controlling the effect of polymerization shrinkage stress in composite restorations. In: SIMPOSIO ITERNAZIONALE DE ODONTOIARIA ADESIVA E RICONSTRUTIVA, 4., S. Margherita Ligure, 2000. Atti. Italy, Probagonsti in Odontoiatria, 2000. p.60-67. 
73. SUH, B.I.; CINCIONE, F.A.; SANDRIK, J.L. Examination of experimental cavity substrate as a function of modulus of elasticity during polimerization of composite. J. dent. Res., v.77, p.261, 1998, Special Issue (AADR abstracts) / Abstract n.1242.

74. SUH, B.I.; WANG,Y. Determining the direction of shrinkage in dental composite by changes in surface contour for different bonding configurations. Amer. J. Dent., v.14, n.2, p.109-13, April 2001.

75. TAM, L.E.; Mc COMB, D.; PULVER, F. Physical properties of proprietary lightcured lining materials. Oper. Dent., v.16, n.6, p.210-7, Nov.-Dec. 1991.

76. TAPETY, C. M. Influência da interposição de base na infiltração marginal em cavidades classe II (MOD), restauradas com resinas compostas para dentes posteriores. Bauru, 2001. 140p. Dissertação (Mestrado) - Faculdade de Odontologia de Bauru, Universidade de São Paulo.

77. TESSORE, G.; TRINCHERO, A. Post-operative sensitivity consequent to composite restorations in posterior sectors. In: SIMPOSIO ITERNAZIONALE DE ODONTOIARIA ADESIVA E RICONSTRUTIVA, 5., S. Margherita Ligure, 2001. Atti. Italy, Probagonsti in Odontoiatria, 2001. p.62-65.

78. TOLIDIS, K.; NOBECOURT, A.; RANDALL, R. C. Effect of a resin-modified glass-ionomer liner on volumetric polymerization shrinkage of various composites. Dent. Mat., v.14, n.6, p.417-423, Nov./Dec. 1998.

79. UNO, S; ASMUSSEN, E. Marginal adaptation of restorative resin polymerized at reduced rate. Scand. J. dent. Res., v.99, p.440-4, 1991.

80.UNTERBRINK, G.L.; LIEBENBERG, W.H. Flowable resin composites as "filled adhesives": literature review and clinical recommendations. Quint. Int., v.30, n.4, p.249-257, 1999.

81. VERSLUIS, A. et al. Does an incremental filling technique reduce polymerization shrinkage stresses? J. dent. Res., p.75, n.3, p.871-878, Mar. 1996. 
82. VERSLUIS, A.; TANTBIROJN, D.; DOUGLAS, W. H. Do dental composites always shrink toward the light? J. dent. Res., v.77, n.6, p.1435-45, June 1998.

83. VERSLUIS, A.; TANTBIROJN, D. Theoretical considerations of contraction stress. Comp. Continuing Educ. Dent., v.20, p.24-32, Nov. 1999.

84. YAP, A.; SOH, M. S. Thermal emission by different light curing units. Oper. Dent., v.28, n.3, p.260-6, 2003.

85. YAP, A. U. J. et al.; WANG, H. B.; SIOW, K. S.; GAN, L. M. Polymerization shrinkage of visível light cured composites. Oper. Dent., v.25, p.98-103, 2000. 
ABSTRACT 


\section{ABSTRACT}

The aim of this study was to verify the influence of the type of composite resin (chemical-cured and three different type of photo-cured composite); the type of photocuring unit (halogen and LED); and the type and thickness of different intermediate materials (flowable composite and resin modified glass ionomer) on the polymerization contraction forces transmitted to an universal testing machine. The experiment set up consisted of two identical steel bases one of which was connected to the cross head of an universal testing machine and the other was fixed to the transversal base. Composite resin was inserted into a $1 \mathrm{~mm}$ space between the steel bases or between the inferior steel base and a previously polymerized layer of an intermediate material adhered to the upper steel base. The resin composite was light-cured with a QTH or LED curing unit for 60 s and a curve force/time was obtained for each of the ten samples. The data were statistically evaluated using one way ANOVA and Tukey tests $(p \leq 0,05)$. It was observed that the chemical-cured Concise produced the lower means of polymerization contraction forces; The photo-cured composites developed forces at the moment photoactivation began and for the whole evaluated period. Polymerization contraction forces were more dependent of power density than of the light source (halogen or LED). The use of resin modyfied glass ionômer as an intermediate layer promoted a significant decrease in the polymerization contraction force values of the restorative system, regardless of layer thickness. The use of flowable composite as an intermediate layer promoted an increase in polymerization contraction force values of the restorative system with the two evaluated layer thicknesses 